\title{
الطبيبات والمشتغلات بالمهن الطبية
}

\section{خلال الفترة من القرز الأول حتتى القرز التناسع الهجري:}

\section{دراسة مقارنة بيزن الشرق الإسلاميي والغرب الأوربي؟}

\author{
د. هيلة بنت عبد الرحمن بن فراج الثراج السهلي
}

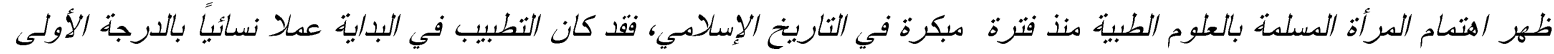

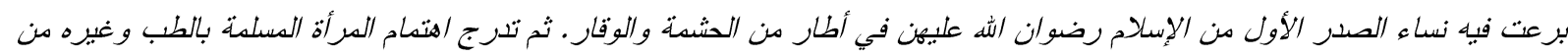

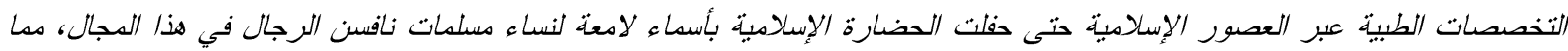

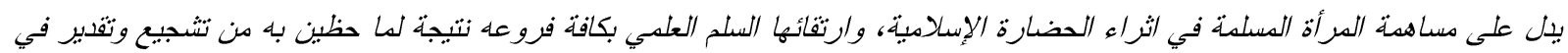

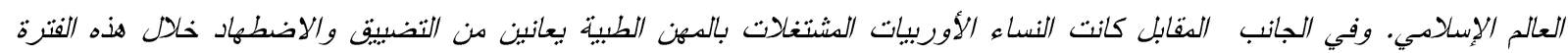

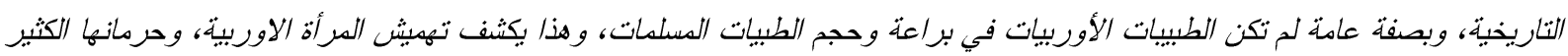

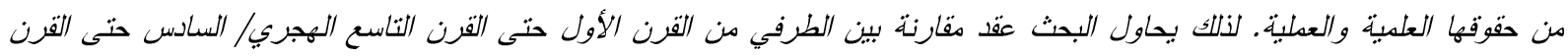

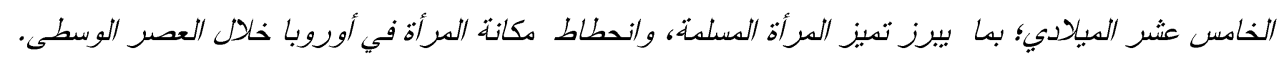
الكلمات المفتاحية: طب، مهن طبية، المرأة المسلمة، الحضارة الإسلامبة، المرأة الأوربية.

\section{Abstract}

The paper provides a historical review about health care in Muslim women experience. The Muslim women engaged in health care from the very early days of Islam. The medical care was women work in the era of prophet Muhammad peace be upon him. And the Muslim women gradually developed their concerns of medicine and other health care professionals through ages. Thus, Muslim women play a significant role in the Islamic civilization. Thanks to the encouragement of Islam teachings and Muslim society. On the other side, the European women are profoundly affected by social and religious factors that prevented her from fully practicing medicine. This paper offers Comparative study between Muslim and European women From the First Century to The Ninth Century Hajri Between Islamic East and European West to highlight what is distinctive about Muslim women over the Europeans in the field of treatment and health care during medieval.

Key words: medicine, medical professionals, Muslim women, Islamic civilization, European women.

اشتهرث الشفاء بنت عبد الله بالطب وبمعالجتها لمرض جلدي من نوع الإكزيما، وهي جروح

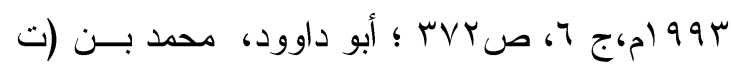

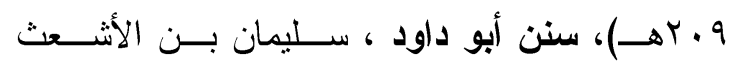
السجستاني (ت Y Y Iــ)، موسوعة الكتــب الســتة،

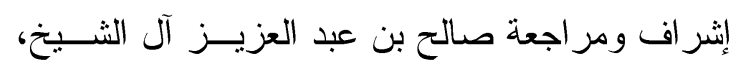

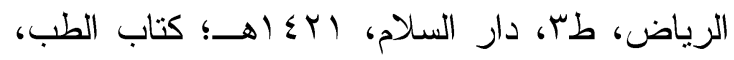
باب في الرقى، حديث رقم9 حمب؛ ابن عبــد البــر، يوسف بن عبد الله (ت سجاءهــ/ • V • (م)،الاستيعاب في معرفة الأصحاب، تحقيق: علي محمد البجــاوي،

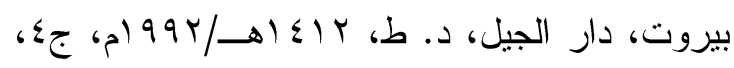
ص
لم يقتصر النبوغ في العلوم الطبيبة على الرجال فقط، بل اسهمث النساء بحظ و افر في هذا المجال، فقد نبخ عدد ليس بالقليل من النساء، كأم عطبة الأنصارية، وكانت مشهور كطبيبة في الجاهلية، وبعد دخولها في الإسلام، و غزت مع

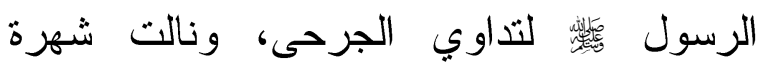
عظبمة في الجاهلية و الإسلام بالجراحة'، كما ' ابن حنبل، أحمد بن محمد (ت إ؟بهـــ)، المســـا،

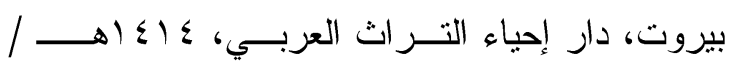


الجليلة أسماء بنت أبي بكر (ذات النطاقين) مهنة

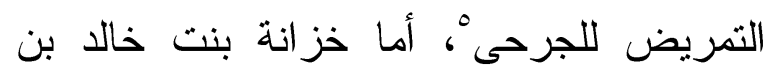
جعفر بن قرط، فقا عرفت بممارسة الطب و التمريض". ويتضح مما سبق اهتمام المرأة المسلمة بالعلوم الطبية منذ فترة باكرة من تاريخ الإسلام، وأن ذلك كان عملا نسائياً بالدرجة

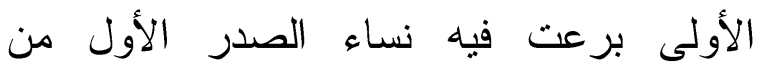
الإسلام رضوان الله عليهن في أطار من الحشمة لهنهاء و الوقار، وبعيداً عن السفور و الابتذال. فالإسلام ساوى بين الرجل والمرأة في الامور الدينية

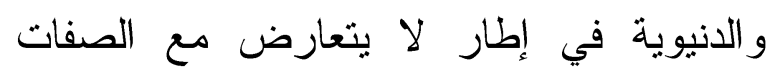
الفسيولوجية و النفسية و البدنية لكل منهما، قال

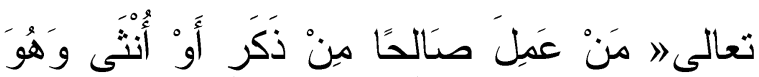

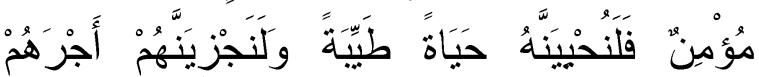

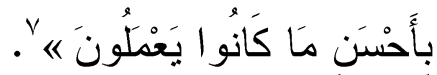

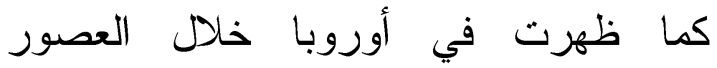
الوسطى نساء مارسن عدداً من المهن الطبية، ولكن على نطاق ضيق لأسباب متعددة سنناقشها

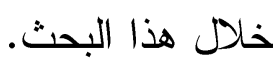

وزعم المستشرقون تهيش المرأة في المجتمعات الاسلامية خلال العصور الوسطى،

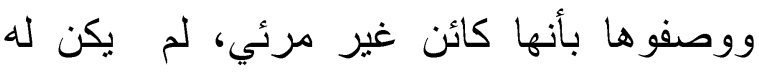
دور و ولا مساهمة في النواحي العلمية

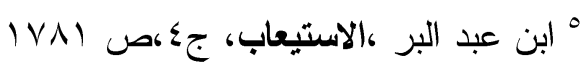

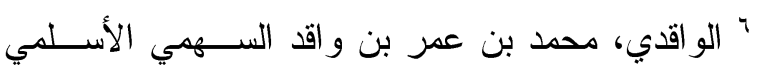

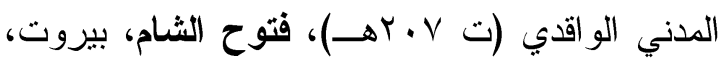

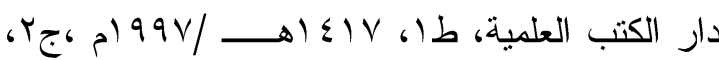

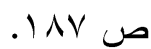

تظهر بالجنبين، ويحس المريض كأن نملة تدب

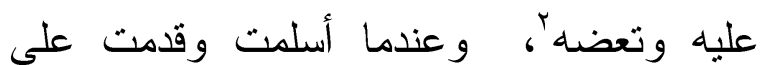
الرسولك عرضت عليه طريقة علاجها لهذه المرض الذي يسمى "النملة"، حيث كانت تستخدم أعواد الكركم، وتدلكها على حجر عليه خل، لأل فيعلق بالعود ثم تطليه على القروح بعد ان تقرأ

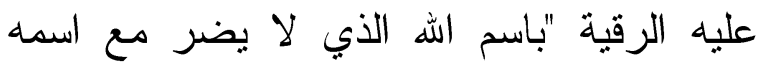
أحد، اللهم أكثف البأس رب الناس" سبع مرات التان التان

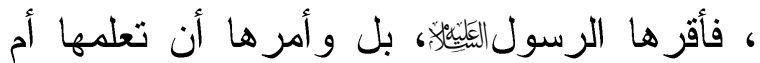
المؤمنين حفصة رضي الله عنها " علمي حفصة رقية النمل كما علمتها الكتابة."r، وهكذا كانت الشفاء تجمع بين العلاج الروحي و العضوي. ولا ننسى رفيدة الأسلمية، التي نبغت في النياتي

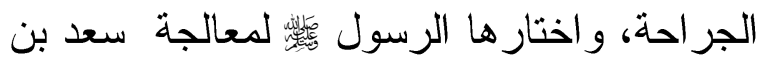
معاذ عندما أصيب برمية في معركة أحد، كما كان ختان الصبيان مألوفاً قبل الإسلام، وكانت أم عطية الأنصارية رضي اله عنها تمارس هذه

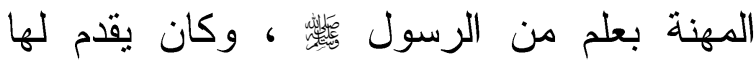
النصح في هذا المجال؛. كما مارست الصحابية

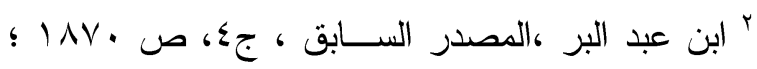

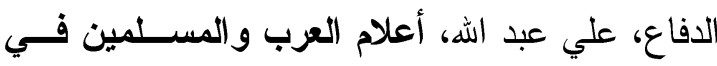

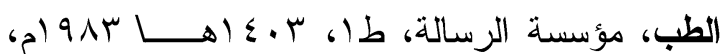

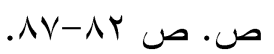

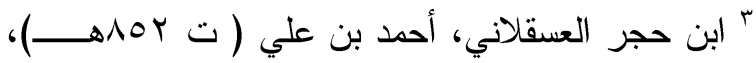

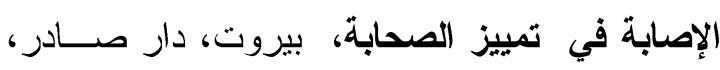

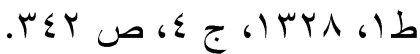

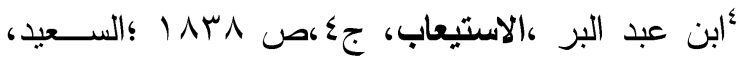

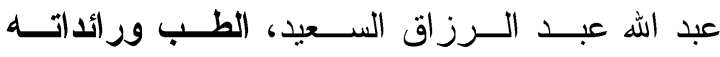

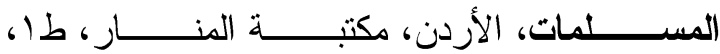
. I 


\section{تطور اشتفال المرأة بـالمهن الطبية في العالمين}

الإسلامي و الأوروبي من القرن الأول الهجري حتى

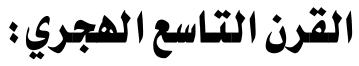

اتسم العصر النبوي بوفرة في عدد الطبيبات

و المعالجات، وقد يكون سبب هذه الوفرة النسبية حرص المؤرخين وكتاب السيرة على تدوين أخبار تلك الفترة بكل تفاصليها، خاصة وأن

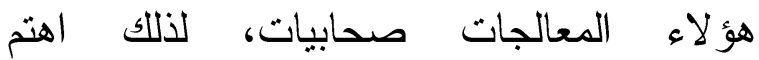
المؤرخون وكتاب السيرة و الطبقات، على تتبع

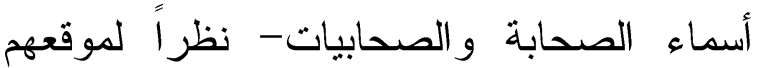

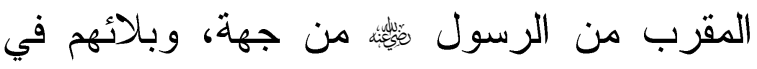
الإسلام من جهة أخرى- مما أمدنا بفيض نسبي وني لهني في عدد المعالجات، و المشتغلات بالمهن الطبية،

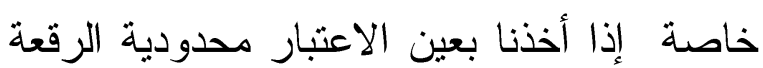
الجغر افية، وقلة الكثافة السكانية في تلك الفترة، ثم أخذ هذا الفيض ينحسر تدريجياً من كتب المؤرخين و أصحاب الطبقات الذين أهملوا ذكر لأل الهر الطبيات، و وغيرهن من العاملات في المهن الطبية، حتى تلك التي اهتمت بطبقات الأطباء،

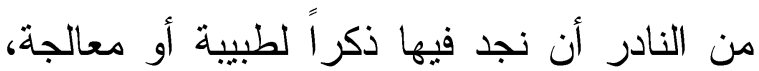

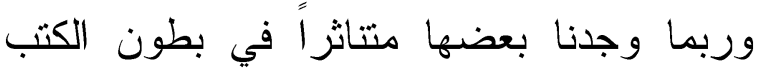
التاريخية، ولكن لا يعني هذا عدم وجود هذه الفئة في العالم الإسلامي خلال العصور الوسطى؛ بل على العكس من ذللك، فإن هذا الإشارات دليل قاطع على وجود الطبيبات و المعالجات طيلة العصور الوسطى في العالم الإسلامي ، و على امتداد نطاقاته الجغرافية
و الاجتماعية بسبب القيود الثرعية، و التزمت الديني خاصة في المهن الطبية. لكن استقراء التاريخ يكثف مدى مساهمة المرأة المسلمة، لاهن وارتقائها السلم العلمي بكافة فروعه و اشتغالها بالكثير من المهن في حدود الحشمة و الوقار، بما في ذللك المهن الطبية. وفي نفس الوقت يكثف مدى تهميش المرأة الاوربية، وحرمانها الكثير من حقوقها العلمية و العملية، فهؤلاء المدعون ينطبق عليهر المتل العربي" رمتتي بدائها و انسلت"، لأنهح رموا المسلمة بداء الأوروبية، تعمية للواقع المرير الذي عاثتها ولا تزال تعيشه المر أة في المجتمعات الأوروبية. و هذا البحث يحاول أن يرد على ادعاءات المستشرقين، وييرز تميز المرأة المسلمة على

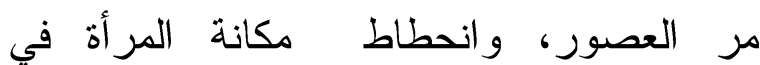

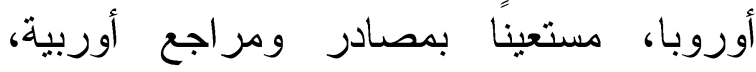
فالحق كما يقال ما شهدت به الأعداء. وذللك من خلال المباحث التالية: المبحث الاول: تطور اشتخال المرأة بالمهن الطبية في العالمين الإسلامي و الأوروبي من القرن الأول الهجري حتى القرن التاسع الهجري. المبحث الثاني : طرق وأماكن الدراسة والتدريب. أما المبحث الثالث فهو: التخصصات و وأساليب العلاج. و المبحث الرابع : لاختبارات الطبية و الرخصة المهنية، بالإضافة إلى الخاتمة التي شملت أهم

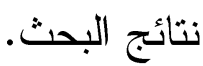

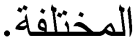


تمكنا من معرفتهن، لذلك فأغلب الظن أن معظم الطبيبات و المعالجات في العالم الإسلامي خلال العصور الوسطى كن طبيبات للعامة خاصة من النساء.

ومما يؤكد أن الطبيبات و المعالجات كن حاضرات في المجتمع الإسلامي خلال العصور الوسطى ما ذكره ابن حزم من أن الطبيبة كانت

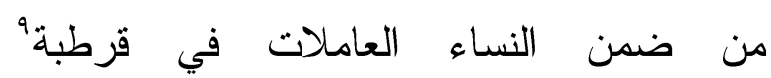
9 قرطبة: مدينة تقع على نهر الو ادي الكبير في الجــزء

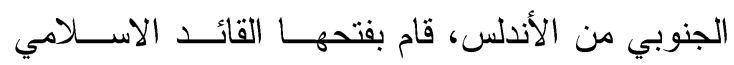

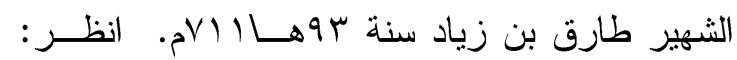

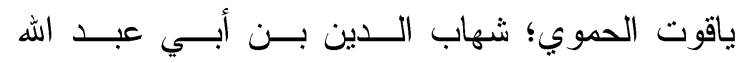

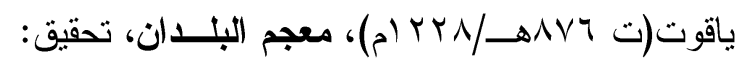
فريد عبد العزيز الجندي، بيروت، دار الكتب العلمية،

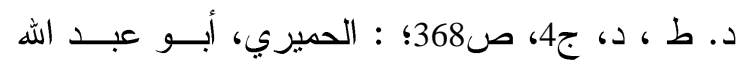

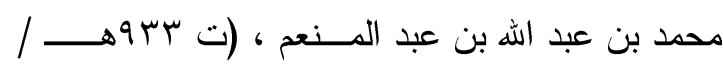

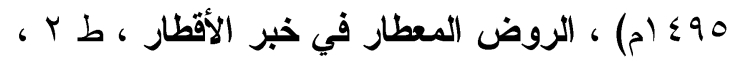

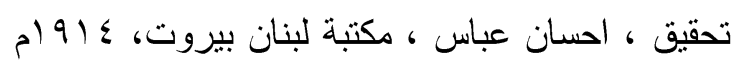

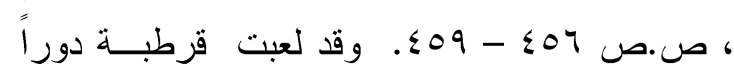

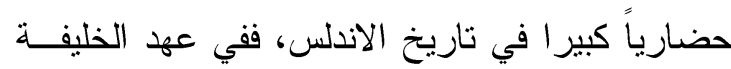
عبد الرحمن الناصر، و ابنه الحكم المستتصر من بعده،

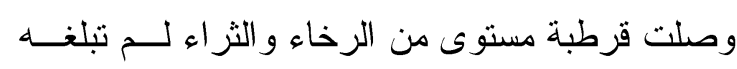

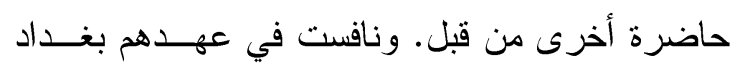

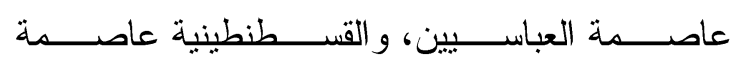
الإمبر اطورية البيزنطية، و القاهرة عاصمة الفاطميين.

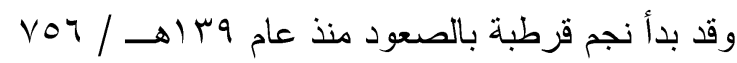

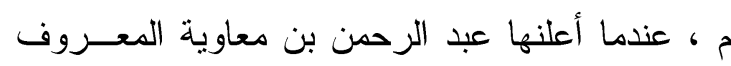

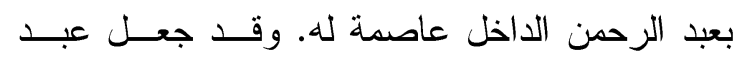

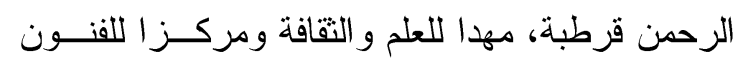

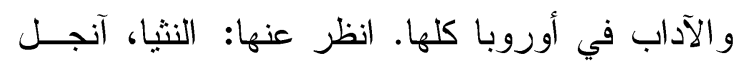

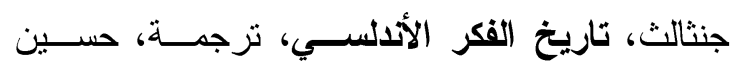

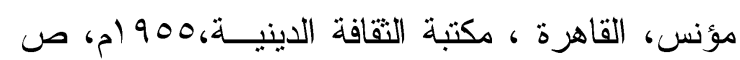

وردًا على من يدعي أن ذلك له علاقة بقضية الجندر، وحجتهم في ذلك أن النساء في العالم الإسلامي خلال العصور الوسطى، بالكاد يظهرن بوصفهن طبيبات أو مريضات، ويدللون على ذللك أن محرر ات موسو عة النساء و التقافات الإسلامية كان عليهن أن يطلبن من أحد من غير المتخصصين في التاريخ الإسلامي كتابة مقال لبحث قضية الجندر في العالم الإسلامي ^؛ نقول إن الحقيقة في عدم اكتراث كتب التاريخ و التراجم و الطبقات بتسجيل أسماء الطبيبات لا لو لو يعني غيابهن عن الساحة العلمية و العملية في العالم الإسلامي، فكتب التزاجم و الطبقاث خاصة الطبية منها، لم تسجل سوى أسماء الأطباء

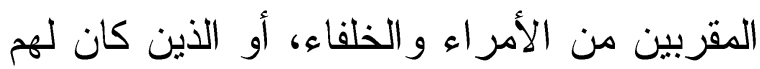
انجازات طبية كبيرة ومتميزة كالرازي و ابن سينا و الز هراوي و غيرهم، ولم تلتفت إلى أطباء

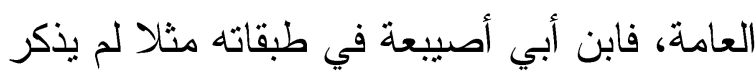
كل الأطباء الأكور في كل العصور التي سبقت عصره، ورإلا لكلفه ذلك تأليف ألاف هن المجلدات، حتى أطباء عصره اقتصر في ذكرهم على النابغين، و أطباء الخلفاء و الأمر اء و علية

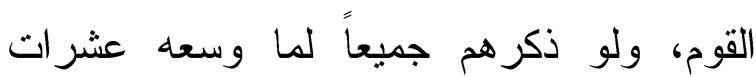
المجلدات حتى يحصيهم، لذلك اقتصر في ذكره لطبيبات على الثهيرات و النابغات منهن، ولم يتطرق إلى طبيبات العامة، حتى كتب طبقات التي ذكرت الطبيبات في العهد النبوي ذكرتهن بوصفهن صحابيات بالدرجة الأولى، وإلا لما قرين، مونيكا، تاريخ العلم، د.ط. م..ت، ص דمءـ. 
بالأندلس"'، وعلى الرغم من ذللك لم تذكر الإسلامي، و استطاعت المرأة المسلمة بذلك الحصول على تعليم طبي أكثر دقة وتخصصاً على بد طبيب متخصص حصل على معرفته المصادر الأندلسية أسماء طبيبات في تز اجمها، الطبية عن طريق الدراسة المنهجية و التدريب رغم ذكرها عدداً كبيراً من أطباء قرطبة على طئل العملي في إحدى المستشفيات الكبرى المعروفة في العالم الإسلامي في ذلك الوقت، حبث بصبح هو المعلم الخصوصي لابنته، فق نبغت في أسرة الطبيب الشهير ابن زهر أربع طبيبات هن شقيقة الحفيد أبي بكر محمد بن أبي مروان بن زهر وكانت توصف بانها طبيبة مولدة، وابنتها كانتا عالمتين بالطب و المداواة ولهما خبرة كبيرة بعلاج أمر اض النساء، وكذلك ابنته التي يدعوها البعض بالحفيدة بنت الحفيد، و ابنتها، وجميعهن كن ماهر ات في صناعة الطب و المداو اة، ولديهن خبرة ممتازة فيما يتعلق بالأمر اض النسائية و الولادة، وكانت أسرة ابن زهر الطبية التي اشتهر نسائها ورجالها بالبر اعة في الطب تسكن في إثبيلية في الفترة الواقعة بين القرنين الخامس و السابع الهجريين \الحادي عشر و الثالث عشر المبلاديين 'ا . و لا شك أن بنات عائلة ابن زهر، كن محظوظات أكثر من غيرهن، لأن نشأتهن

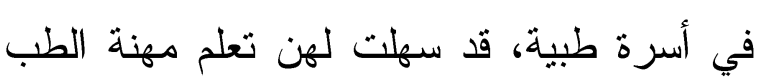
على أيدي أطباء متخصصين، يعدون من أنبغ علماء العصور الوسطى، والأمر ذاته بقال عن

r' ابن أبي أصيبعة؛ موفق الدين أبو العباس أحمــــــن

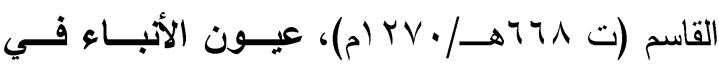

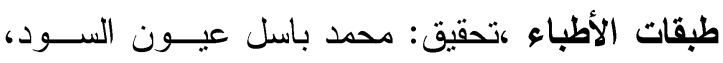

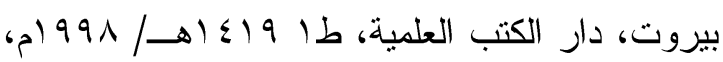
سبيل المثال، ربما لاقتصار تلك التراجم على الأطباء المشهورين في قرطبة فقط. أضف إلى ذلك الفتوى الواردة في نوازل ابن سهل حول "اختلاف الطبيب و المداوي في الأجر"، وكان محور هذا الفتوى يدور حول نزاع وقع بين امر أثين حول الأجرة إحداهما طبيبة و الاخرى أم لصبيتين كانتا تتلقيان العلاج على يد تلك الطبيبة"'. و يتضح ما سبق أن النساء اللاتي يعملن في الحقل الطبي في العالم الاسـامي خلا العصور الوسطى كان يطلق علبهن مسمى " طبيبة"، كما يطلق على الرجل اسم" طبيب". وأدى تطور الحضارة الإسلامية إلى ظهور طبيبات في كافة أقطار العالم الإسلامي، وفي مختلف فتزاته التاريخية خلال العصر الوسيط، ورافق هذا التطور الحضاري أيضاً تطور طرق تعلم المرأة الطب و الجراحة، فقد صاحب ذلك بروز العديد من الأطباء النابغين في العالم

I V Vـــؤنس، حســـين، معــالم تـــاريخ المغـــرب

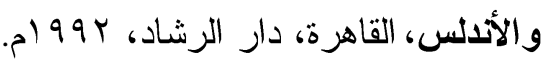

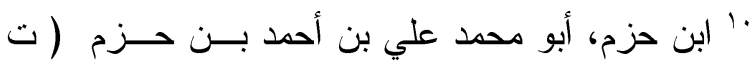

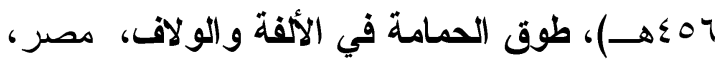

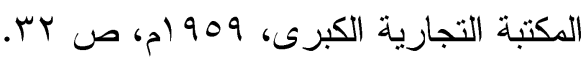

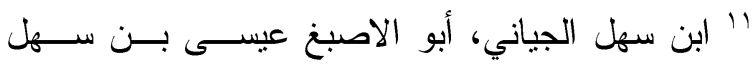

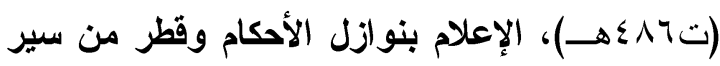

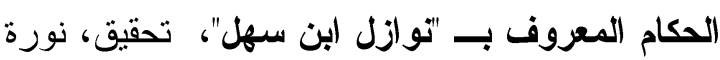

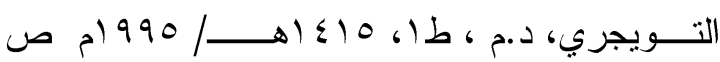


طبيبة متميزة، كانت تجيد فن الصناعة الطبية و الأدبية، وقد اشتهرث بمداو اتهاء'.

وهكا يتضح مما سبق أن الطبيبة المسلمة جمعت بين العلوم الطبية و الثرعية و الأدبية، مما بدل على حصولهن على لقب الطبيبة العالمة، و هومالم يتوفر لدى المشتغلات في المهن الطبية في أوربا.وكان من أبرز الميزات التي انفردت بها المستشفيات في العالم الاسلامي خلال العصور الوسطى دور الطاقم الطبي النسائي فيها، فمن النادر أن توظف النساء في أماكن العلاج في العالم خلال العصور القديمة

1' هي سارة بنت أحمد بن عثمان بن الصدلاح الحلبيـة،

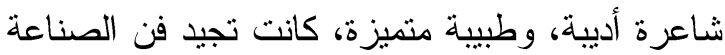

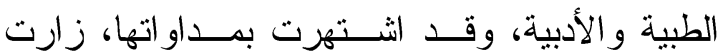
الأندلس، ومدحت أمر اءها، كما وفدت على المستتصر

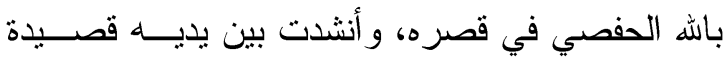

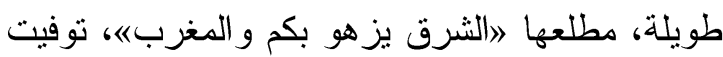

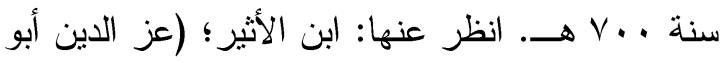

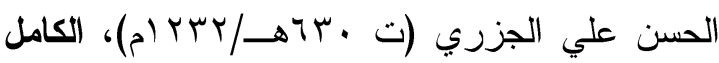
في التاريخ، تحقيق: عبد السلام تدمري، بيروت، دار

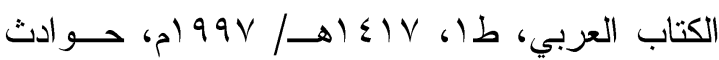
سنة SVY وما قبلها. أبو الفداء، (إسماعيل بن علـي اهي

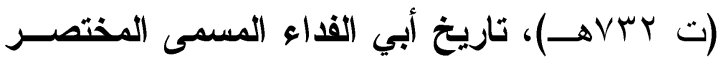

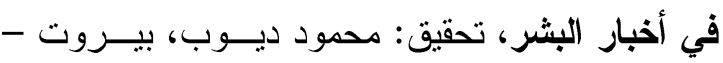

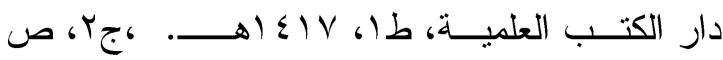

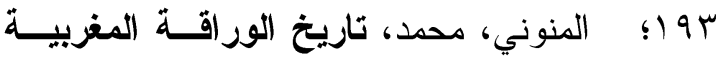
صناعة المخطوط المغربي من العصر الوسـيط إلــى الـى

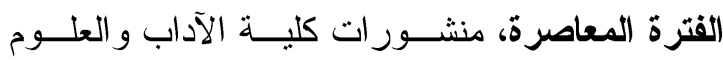

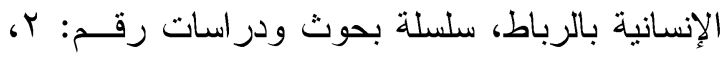
مطبعة النجاح الجديدة- الدار البيضاء، الطبعة الأولى بلى بلى بلى
ابنة الطبيب شهاب الدين أحمد بن الصائغ (ت

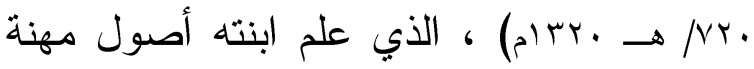
الطب و الجراحة حتى أتقتها ونبغت فيها نبوغاً أهلها لتخلف و الدها في مشيخة الطب دار الشفاء المنصوري بالقاهرةّ”. . وقد اختص المنصور الموحدي المنصور أبي يعقوب بن يوسف بن عبد المؤمن، شقيقة الحفيد وابنتها بعلاج نسائه وكل أفر اد أسرتهء؛

ومن الطبيبات المسلمات ايضاً : الطبيبة 》 أم الم

الحسن « بنت القاضي أبي جعفر الطنجالي ، و كانت طبيبة مبرزة شهيرة في الطب ، كثيرة الاطلاع ، وأجادت علوماً كثير 1، كما كانت بنت دِهن اللوز من الطبيبات الماهرات ،عالمة بالطب، ولا غريب في ذلك فقد كانت والدتها دِهن اللوز من كبريات عالمات دمشق وتوفيت

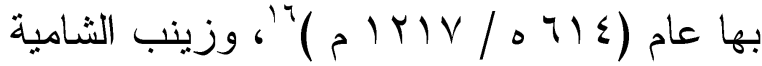
طبيبة نساء خلفاء بني أمية في الأندلس وله وسارة بنت أحمد بن عثان بن الصلاح الحلبية

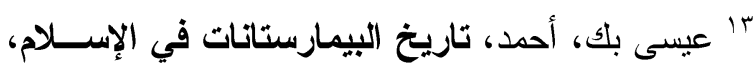

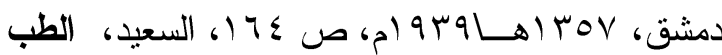

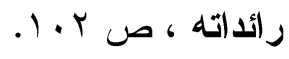

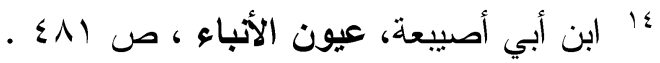

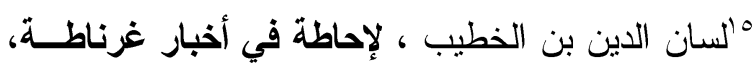

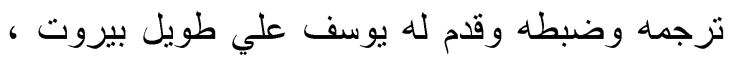

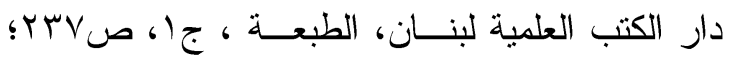

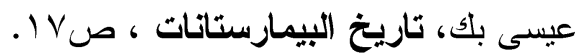

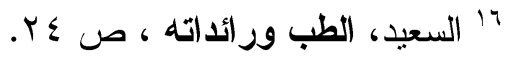

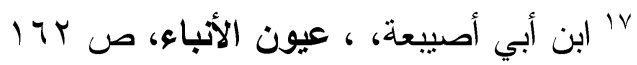


أحمد عيسى بك في كتابه: التاريخ البيمارستانات في الإسلامه حينما قال: 》فقد تخطى الاهتمام بالطب الرجال إلى النساء، فكان منهن طبيبات بارعات، بل كان منهن من تولت مشيخة الطب في حاضرة من أعظم حواضر الإسلامه، وهو يقصد بذلك: بنت الطبيب شهاب الدين أحمد بن الصائغ عن مشيخة دار الثفاء المنصوري بالقاهرة، ولم يخلف إلا بنتا تولت مكانه مشيخة الطب" ب. وقد اعترف احد الباحثين الأمريكان بقصب السبق الذي فازت به الطبيبة المسلمة في سياق حديثه عن بنات آل زهر حيث ذكر أن الطبيبات المسلمات حظين بقبول في العالم الإسلامي قبل أن تخرج جامعة جون هيبكون V.. أول طبيبة امريكية أن Johns Hopkins

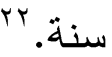

وقد بلغ تقدم الطبي أن أصبحت المرأة المسلمة مصدراً طبياً معتمداً، ومستشاراً طبياً موثوقاً للمسلمين وغير المسلمين، فقد عدد ابن البيطار خلال القرن الساد الهجريا الثاني عشر الميلادي مصادر مفرداته فتجاوز عدد الأطباء الذين ذكرهم المائة و السبعين طبيبا، بينهم طبيبة، وفي استشارتين طبيتين إحداهما

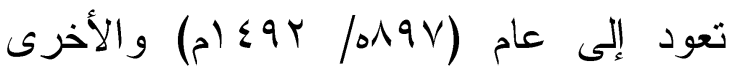
(10.1/09.V)

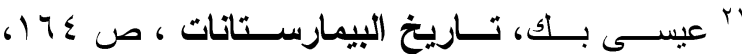
السعيد، رائدات الطب، ص ب ب. 1.

22 Tschanz, David. W, Pioneer Physicians,

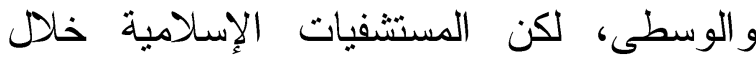
العصر الوسيط كانت بشكل عام توظف الممرضات، حتى من المناطق البعيدة، بغض النظر عن خلفياتهن الدينية و الثقافية والعرقية، لأن هذه المستشفيات كانت تضم موظفين من أماكن شتى مختلفة، كما شهدت المستشفيات في هات العالم الإسلامي انطلاقة أخرى هامة، وهي أنها أول من وظفت الطبيبات فيها، حيث كانت المستشفيات الإسلامية تنقسم إلى قسمين متساويين أحدهما للاجال والآخر للنساء، ولكل قسم فريق من الأطباء والمدرضين من نفس الجنس

وعرفت الطبيبات في العالم الإسلامي نظام العيادات الخاصة، ونظام الزيارات المنزلية لمداواة مرضاها مثلها مثل الرجال، فقد ذكر

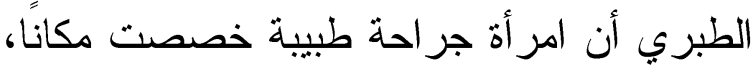
هو أشبه بالعيادة في وقتتا الحالي، لمعالجة مرضاها، وكان المرضى يأتون إلى هذا المكان

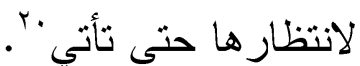

وتدرجت الطبيبات المسلمات في ارتقاء السلم الطبي حتى بلغن رئاسة المستشفيات الكبرى في العالم الاسلامي آنذاك، كدار الثفاء المنصوري بالقاهرة، حيث احتلت بنت شهاب الدين أبي الصائغ منصب "رئيس الأطباء" وهو مالم تبلغه الطبيبات في أوربا، وقد أشار إلى ذلك الكاب

${ }^{19}$,Wikipedians, Medicine, Pedia Press, p. 113

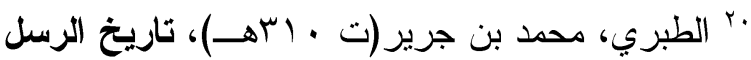

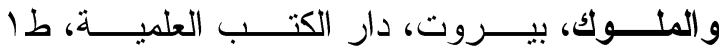

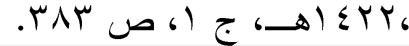


و النهضة العلمية التي شملت حواضر الأندلس

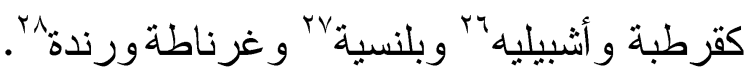

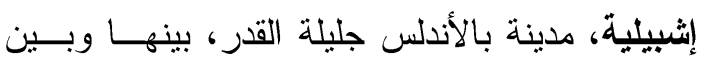

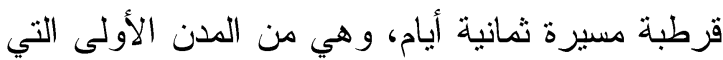

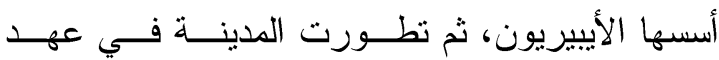

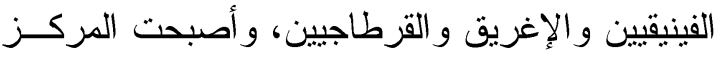

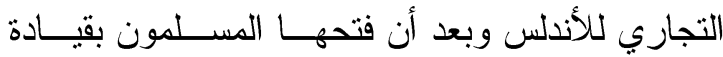
طارق بن زياد أختارها موسى بن نصــير حاضــرة

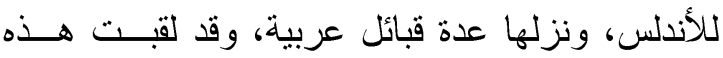

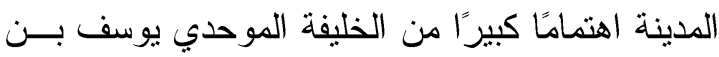
عبد المؤمن. انظر : الحميري، الــروض المعطــار،

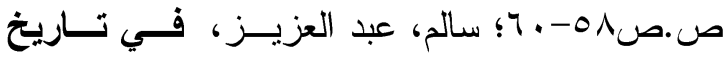

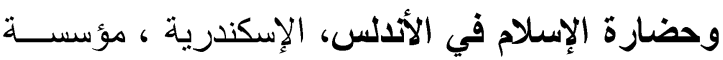

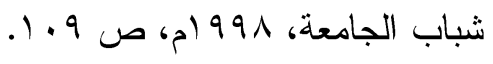

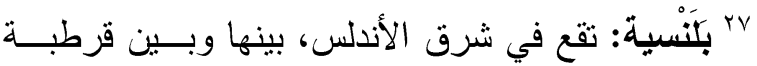

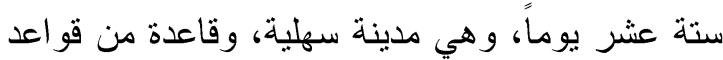

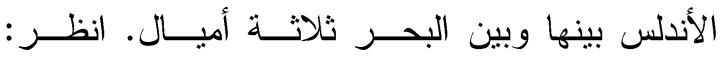

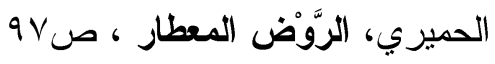

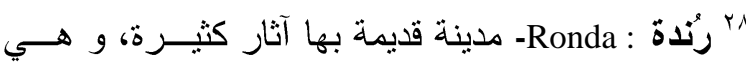

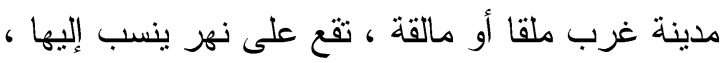

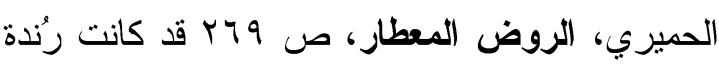
من أهم القو اعد الأندلسية التالدة، ثم كانت بعد ذلك من من أهم مدن مملكة غرناطة الإسلامية، و لما سقطت رُندة الند

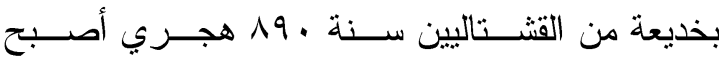
الطريق ممهدا لاستيلاء النصارى على مالقة و بالفعل

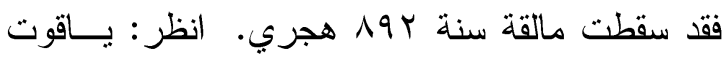
الحموي، معجم البلان، ج3، ص 84؛ عبداله عنــان، نهاية الأندلس، القاهرة، مطبعة لجنة التأليف و الترجمة

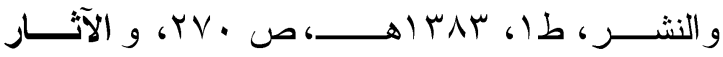

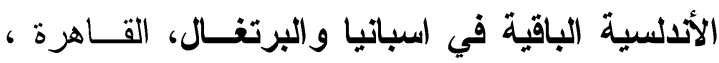

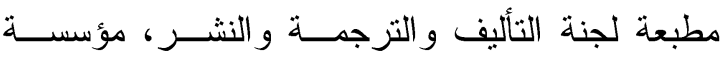

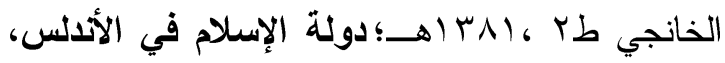

مسلمين بينهم امرأه بـوفي مقابل تراجع عدد الطبيبات و المعالجات الأوربيات، نلاحظ ازدياداً مضطردًا في عدد الطبيبات المسلمات، فقد فاق عددهن في الأندلس البهوديات و النصر انيات، و إذا كانت المصادر الإسلامية والاندلسية سكتت عن هذا الأمر، فإن الوثائق الاسبانية التي تعود إلى القرن السابع حتى التاسع الهجريا الثالث عشر حتى الخامس عشر المبلادي قد أشارت إلى عدد كبيز منهن.و طبقًا لما ذكرته مونيكا قرين فإن الوثائق الرسمبة التي تخص مملكة أرغون، أظهرت بجلاء أن الطبيبات المسلمات اللاتي تقدمن للحصول على رخصة مز اولة مهنة الطب في مملكة أرغون خلال القرن الثامن الهجريا الرابع عشر الميلادي فاق غيرهن غّ؛ والأمر ذاته يقال عن الطبيبات المسلمات في بلنسية خلا هذا القرن. وترجع الباحثة الشعيري ro تطور مواهب الهر أة المسلمة في الأندلس في الطب و غيره من العلوم إلى سببين رئيسين: أولهما البيئة الأندلسية المتطورة السمحة هلئ التي وجدت فيها، وثانيهما الازدهار الثقافي

${ }^{23}$ The Age of Catholic Monarchs, 1476-1516: Literal Studies in Memory of Keith Whinom, Liverpool, 1989, pp.5-71.

24 Nierenberg, David, Communities Of Violence : persecution of minorities In The Middle Ages, New Jersey, Princeton University Press, 1998,pp. 120-121.

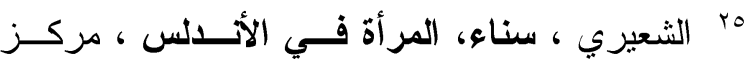
دراسات الأندلس وحوار الحضارات ، مطبعة الأمينة . 


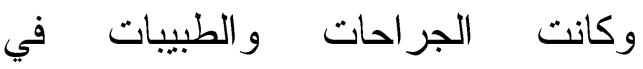

الأناضول خلال هذا القرن يعملن جنباً إلى جنب

مع الرجل، مع المحافظة على حشمتهن وحيائهن ودون اختلاط، فقد عمل الطبيب التركي شرف الدين مع العديد من الجراحات في وقت كان زملاؤه في أوروبا بشون بالمعالجات و الطبيبات، كما كانت الجراحات في منطقة الأناضول يجرين عليات جراحية لبعض الأمر اض التي تصيب الجهاز التتاسلي للإثاث كالثآليل والبثور، و المخاض الذي يكون فيه الجنين أو المشيمة في غير وضعها الطبيعي".زد على ذلك وجود أقسام مستقلة للنساء في كل المستشفيات التي تم انشاءها عبر

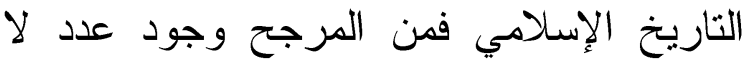

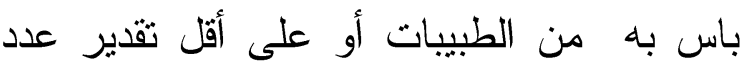
كاف من الممرضات لرعاية المريضات في هذه

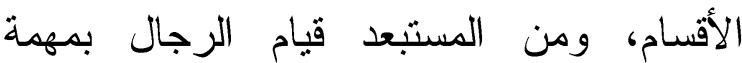
تمريض النساء كما هو الحال في أوربا.

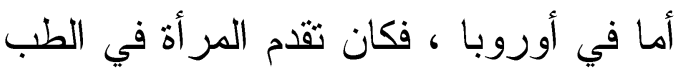
وغيره من العلوم الطبية بطيئً، ولعل ذلك عائد

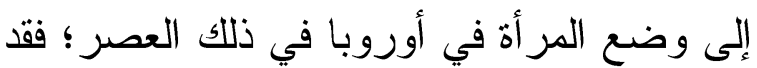
كان مركز الكنبسة قوياً في الغرب الأوربي،

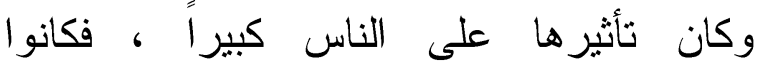
يستمعون لما يقوله الكهان عن الطريقة التي يجب أن يتصرفون بها، كما كان الرجال هم الذين يحمون الكنيسة، أما المرأة فليس لهان الرجال
ومما يلفت الانتباه في نطور الطبي للمر أة في العالم الإسلاهي، أننا بدأنا نشاهد في الكتب لطباه

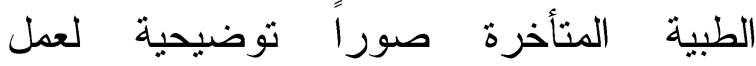
الطبيات، وحتى مطلع القرن التاسع الهجريا الخامس عشر الميلادي كانت الكتب الطبية الاسلامية تزخر بصور توضيحية للأطباء

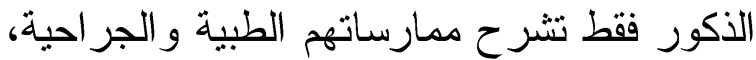
بينما كان يحرم تصوير المعالجات و القابلات بمثل هذه الرسوم التوضيحية و الصور. وكان

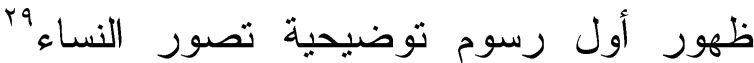

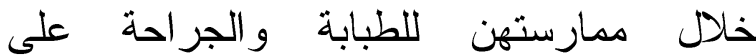
المريضات في القرن الثامن الهجريا الخامس عشر الميلادي، حيث لم يتردد الطبيب التركي شرف الدين في توضيح وتفصيل عملية التوليد، وتعامل النساء مع المريضات أو معالجتهن لبعض الأمر اض النسائية بالرسوم التوضيحية المفصلة، والمثير للاهتمام أن مثل هذه الرسوم ظهرت في منطقة كانت تمثل الخلافة الإسلامية ذللك الوقت، بينما كان هذا النوع من الصور لا لا لالهال يزال محرما في الغرب تحت تأثثر الثقافة الدينية الصارمة، مما يدل على النظرة المنفتحة للأثر الك

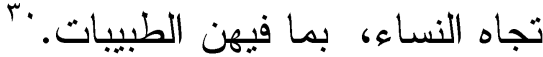

القاهرة، مطبعة لجنة التأليف و التزجمة و النشر، ط، דirkr

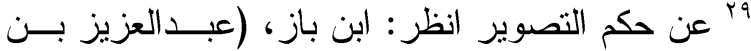

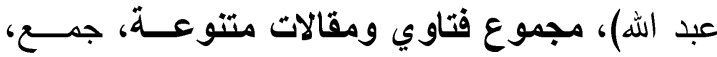

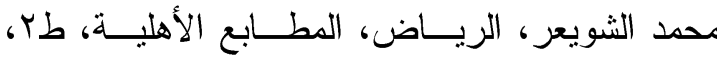

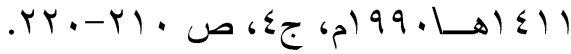

${ }^{30}$ Bademci, First Illustration of Female, Pp.163164 
ندرة وجود الطبيبات في أوربا العصور الوسطى، أن نسبتهن في فرنسا و انجلتز ا وباقي أجزاء أوربا أقل من ب\% من مجموع الأطباء، وكان معظمهن معالجات بالأعشاب، وقابلات أكثر من كونهن محترفات متقرغات للمهنة، ومن المرجح أن أجور هن كانت متدنية؛ّا، فقد بلغ عدد الطبيبات في نابولي بإيطاليا خلال قرنين أربع

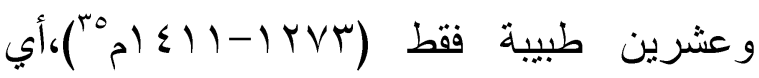
بمعدل اثثتا عشرة طبيبة لكل قرن، كما بلغ عدد

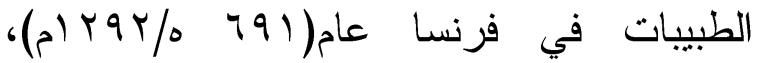
ثماني طبيات من المجموع الكلي للأطباء بـ. ومنذ نهاية القزن الرابع عشر وعلى امتداد القرن

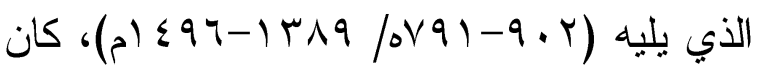
هنالك خمس عشرة طبيبة فقط مرخصة تعمل في

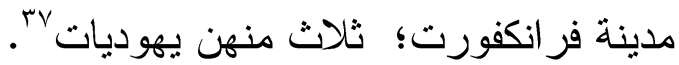
ومهما بكن من أمر، فقد اجمع غالبية الباحثين الأوربيين أن الرجال هم الممثلون التقليديون لمهنة الطب في أوروبا خلال العصور الوسطى، حيث بلغت نسبتهم في الحقل الطبي

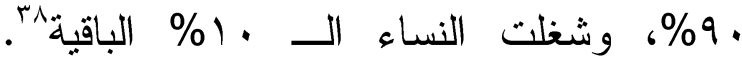

34 Newman, Paul.B, Daily Life in The Middle Ages, Library of Congress, Mcfarland company, Incm, Company, 2001,p.266; Olsen, Kirstin, chronology of Women's History: Profiles Nearly 5000 Women World Wide, Library of Congress, 1994, p. 57 .

${ }^{35}$ Olsen, chronology of Women's History, 1994, p. 57.

36 Applebaum, Herbert, The Concept of Work: Ancient, Medieval, Modern, State University of New York, 1992 ,p. 299.

${ }^{37}$ Olsen, chronology of Women's History, Congress, p.51. .

${ }^{38}$ Shatzmiller, Joseph, Jews, Medicine, and Medieval Society, University of California, California, 1994. P. 108.
الحق أن تصبح كاهنة بّمّ وقد حاولت الدراسة

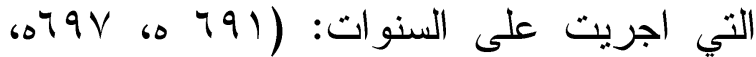
r مهن النساء و الرجال في باريس، ومن بينها المهن الطبية، فجاءت المهن الطبية على رأس

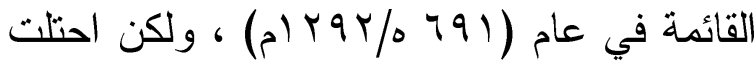
مهنة التمريض النسبة الأعلى من بين أكثر خمسة عشر مهنة شائعة بين النساء، بينما لم نجد

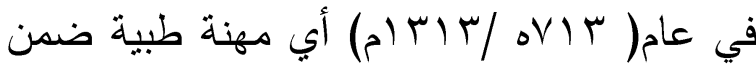
الخمس عشر مهنة الأكثر رواجا بينهن. ولم تضم الدراسة أي ممارس طبي مصنف كجراح بشكل صريح من كلا الجنسين.

أما بالنسبة لمهنة الحلاقين( على اعتبار أن لها علاقة ببعض الممارسات الطبية)، فقد بلغ أصحاب هذه المهنة 9؟ (، ثلاثة عشر منهخ امراة، وفي عام V9 ام بلغ عددهم 1. بينهم خمس نساء فقط، و في عام ساب ام نقص العدد إلى ^\ل، من بينهم امرأة واحدة فقط. اما بالنسبة للقابلات، فكان هناك اثثتان عام (191)

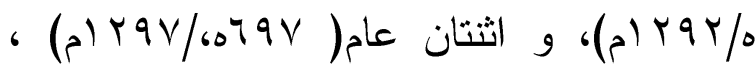

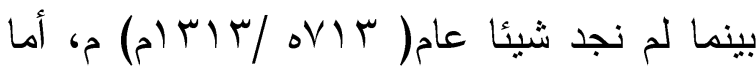
الطبيبات فبلغ عام rو ام ثماني من بين بr

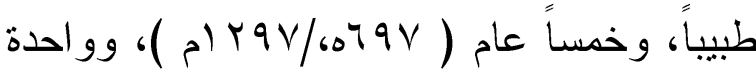

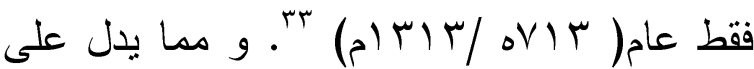

${ }^{32}$ Maintain, Peter and Pulley, Richard, Medicine Through the ages, Cheltenham, England, Stanly Thorens publisher, Second edition, 1997, p.76.

33 Green, Monica, Documenting women doctors during Middle ages in History As Prelude: Muslims and Jews in the Medieval Mediterranean, edited by Joseph V. Montville, p.344. 
ديربنجن Bengin كتابا في الطب العلاجي، وهو كتاب "العلل و العلاج" عام ، 10 المواد الطبية أفسدته في بعض مواضعه بالرقى السحرية، ولكنه مليء بالمعلومات الطبية، وربما كانت الرغبة في القيام بالخدمة الطبية الدائمة من البواعث التي دفعت الشيوخ من الرجال و العجائز من النساء إلى الأديرة"جَ، كما أنشأت مجموعة أخرى من الراهبات دار القديسة كاثرين للعجزة بالقرب من برج لندن، كما قامت الملكة ماتيلدا التي هجرت دير رومسي وتزوجت من هنري الأول بإنشاء

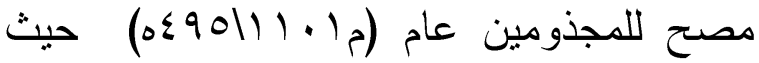
كانت تزعى بنفسها المرضى، كما أسست كلار ا بلاسوني مستشفى للمجذومين في ميلان وشكلت جماعة من الر اهبات للعناية بهر ،؛ . مما بدل على أن المهن النسائية الطبية للأوربيات ذلك الوقت اقتصرت على التمريض و القبالة، فلم تذكر المصادر وجود طبيبات في مستشفى القدس الذي تم انشاؤه بعد سقوط القدس بأيدي الصليبين

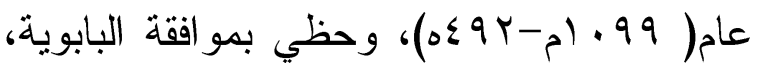
و أصبح مؤسسة خيرية مزدهرة ومنظمة تحتوي على العديد من الأسرة والأطباء، وكانت معظم أعمال التمريض يقوم بها الرجال، مع وجود بعض الدور للنساء، على الرغم من وجود جزء

9 ديور انت، ول، قصة الحضارة ، ترجمة، محمد بدران (طبع الإدارة التقافية بجامعة الدولة العربيــة (د. ط.

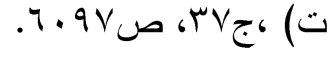

${ }^{40}$ Nikolas, Karl. Borchardt, The Hispitallers, the Mediterranean, and Europe: Festschrift for Anthony, England, Ashgate Publishing, 2007,
و الملاحظ ان معظم اللاتي انخرطن في مهنة الطب في أوربا خلال العصور الوسطى ينتمين إلى الطائفة اليهودية، فقد مارسن الطب في ايطالبا واسبانيا و المانيا وفي اماكن أخرى في المقاطعات علانية وبشكل رسمي، ومن النادر أن نجد طبيبات اوربيات نصر انيات.وفي وثيقة

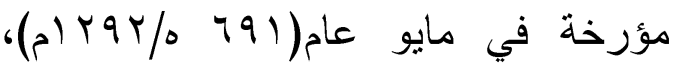
ذكرت طبيبة نصرانية في مانوسك بفرنسا (لوردا دو Laura de Digna تلدعى Manosque دينيا)ضمن قائمة تضم ضمن ثمانية أطباء Mayron رجال، ورنالك الطبيبة اليهودية مايرون

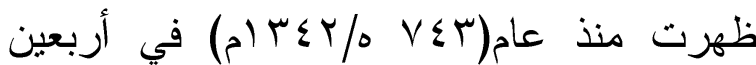
وثيقة، كما وجدت ثلاث طبيبات أخريات ضمن أربعين طبيبا في مانوسك في منتصف القرن الرابع عشر الميلادي، بالإضـافة إلى الطبيبات اللاتي مارسن الطب في مدينة صغيرة في المقاطعة العليا ، يمكن ان يضفن عشرات الطبيبات الكثير منهن يهوديات. ويفهر مما ذكره ول ديورنت أن الر اهبات كن يمثلن الطبيبات أو المعالجات في تلك الفترة إذ كن يو اسين المرضى في هدوء بما يقدمنه من خدمات أو دعوات صالحة، وظلت الر اهبات كغيرهن من رجال الدين يمارسن الطب حتى عام(ع سمه -9 با (م)، وكان كل ما كان هنالك من علاج في المستشفيات كان يوجد عادة أديرة الرجال و النساء، وكان للرهبان في حفظ التراث الطبي من الضياع، وحتى الر اهبات أنفسهن كن في بعض الأحيان بحذقن علاج المرضى، فقد كتبت هيلديرقادر المتصوفة Hildergarde رئيسة 
فرضت القيود على عمل المعالجات على اعتبار أن ما يقمن به أساساً جزء من عمل عل الحلاقين، هذا بالإضافة إلى عدم وجود نقابات تتظم مهنة

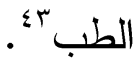

و الملاحظ أن مهنة الطب في الإمبر اطورية

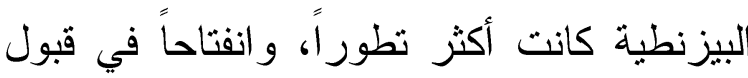
الطبيبات والمعالجات من أوروبا، ويرى هولت باركر Holt Parker أن تاريخ المرأة كمحترفة لمهنة الطب في أوروبا لم يبدا في امريكا عام

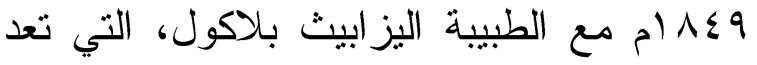
أول أول امر أة نالت شهادة الدكتور اه في الطبه لطبه

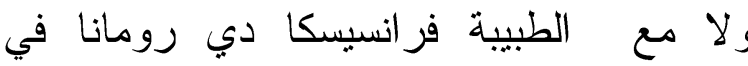

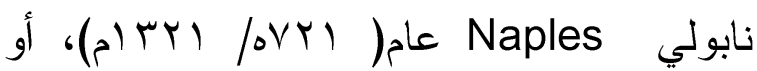
كوستانزا كاليندا عام (بro نابولي أيضاُ، و التي تعد أول امر أة نالت رخصة لممارسة مهنة الطب، ولا هي أيضا الطبيبة Pasquale اليهودية فرديمور ازوجة الطبيب

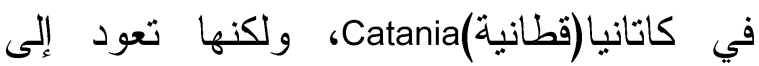
القرن الخامس قبل الميلاد في اليونان؛؛.ققد اعتمد الأوروبيون في العصور الوسطى وبداية عصر النهضة على ما توافر بين أيديهر من

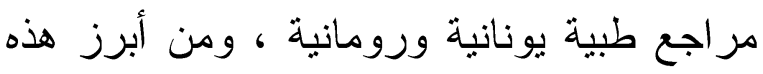

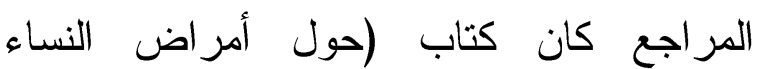
وعلاجها ) للطبيبة اليونانية (ميترودورا)، التي لم يعرف من اسمها غير هذا الاسم الأول

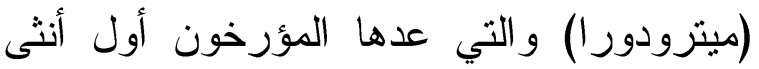

43 The concept of work ,p. 298. Applebaum,

${ }^{44}$ Furst, R. Lilian, Women Healer And Physicians, UNS, The University Press Of California, 1997, p. 57 , p. 131
منفصل للنساء يحتوي على أجنحة لنساء، وقسم

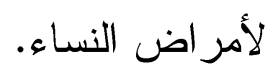

وعلى الرغم من وجود طبيبات محليات،

يعرفن باسم الحكيمات بملكن قدر كبير من

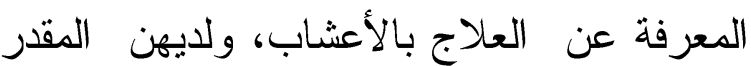

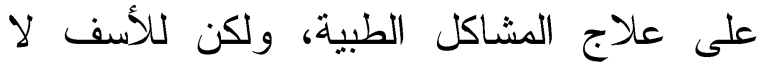
نعرف الكثير منهن، لأنهن لم يكن يجدن الكتابة، كما أن الذين دونوا الكتب التاريخية هم من لان لهنيرن الرجال، هذا على الرغم من وجود العديد من الرجال الذين لا يحسنون الكتابة، ومع ذلك فئل نعرف عنهم الكثير ".ويمكن أن نفسر اهمال ذكر العرابه الطبيبات في أوربا خلال العصور الوسطى؛ أن هذه العصور كانت تمثل العصور المظلمة في التاريخ الأوربي فلا عجب أن تهمش المرأة خلال تلك الفترة، وتستبعد من ممارسة الطب و الطبا الجراحة التي كانت احتكاراً ذكوريًا، وقد يكون ذللك تحيزًا من كتبة التاريخ الذكور، الذين اهتموا بأخبار الرجال أكثر من النساء، كانت الكنيسة

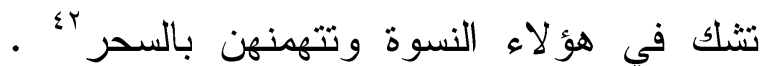
أضف إلى ذلك أن مهنة الطب في أوروبا خلا لال تلك الفترة كانت مرتبطة بالحلاقين، الذين كان

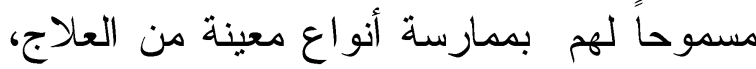

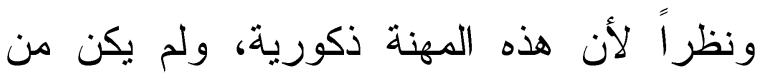
المألوف عمل النساء في مهنة الحلاقة، فقد الدان

${ }^{41}$ Maintain, Peter and Pulley, Richard, Medicine Through the ages, Cheltenham, England, Stanly Thorens publisher, Second Edition, 1997, p.79. rأ نلاحظ أنه في مقابل إهـــال الـــؤرخين الأوربيــين

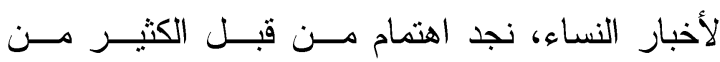
المؤرخين المسلمين بتز اجم النساء 
اشراقته ودقته لمرض أبيها الأخير على اهتمام غير عادي، و موهبة خارقة في المسائل

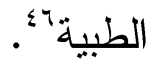

وكان يشرف على مستشفى دير الإله (بانتوقزاتور) الذي اغدق عليه يوحنا الثاني الهبات في عام (100.0/ rالم) عشرة أطباء

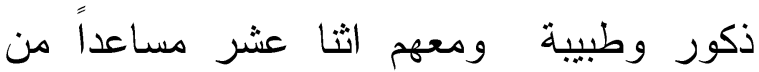

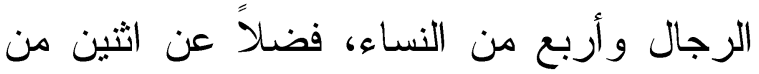
المعاونين الاضافيين و اثتتين من النساء وثمانية

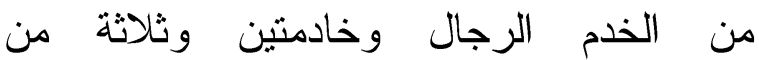
الجراحين، و اثثين من أطباء علم الامراض "البثالوجيا" للقيام بالتشخيص في غرفة خاصة للتشاور، وكانت مستشفيات أخرى أصغر شأناً

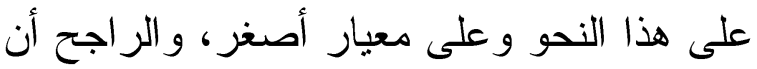
النساء الطبيبات لم يكن يعملن في المستشفيات فقط، كما أنهن كن برندن كثير أ من أديرة النساء في فئاء فهناك الخصيان الذين كانو اليعالجون النساء

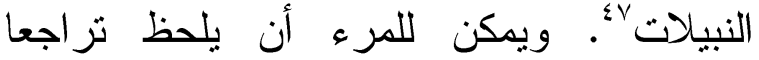

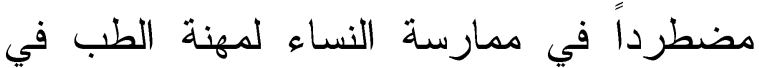

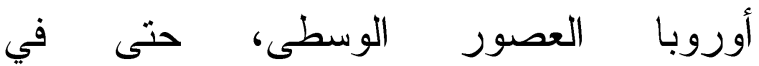
الاختصاصات النسائية كالتوليد و أمر اض النساء،

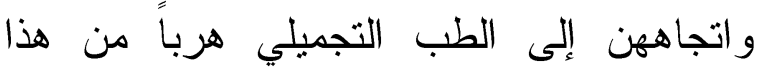

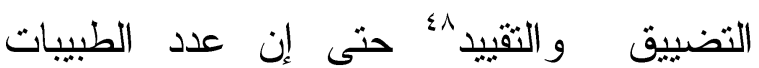

"ا؛ رنسمان، ستيف، الحضــارة البيزنطيـة، ترجمــة،

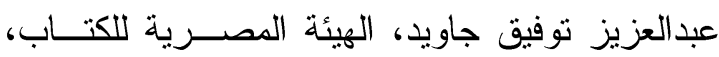

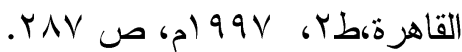

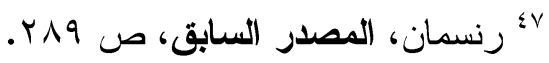

${ }^{48}$ Guardiola , Medieval Mean Girls: On Sexual Rivalry and the Uses of Cosmetics in La Celestina, University of Delaware, Volume 19.2011, p. 174
تؤلف كتباً طبية في العالم. ويظهر جلياً في الكتاب تأثر ها أبو قراط، وتظهر نصوصه الماماً

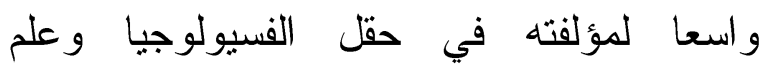

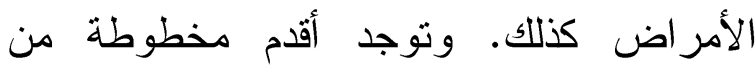
الكتاب الدذكور في مدينة فلورنسا في ايطالياء؛ ورغم وجود بعض النساء اللواتي مارسن الطب في الامبر اطوريتين اليونانية و الرومانية ، خاصة بعد ظهور الطبيبة ( إغناديس) التي تعتبر أول طبيبة انتزعت حق النساء في ممارسة الطب في حضارة اليونان قبل الميلاد، الا أن وجود طبيبة تؤلف كتبًا طبية لم يعرف قبل (ميترودورا) ، ويظهر الكتاب المذكور خبرة سريرية عالية للمؤلفة الطبيبة؛ اذ يظهر أنها كانت تمارس الفحص اليدوي و الفحص باستخدام الـــنظار الفرجي، وقامت بتصنيف الإفرازات المهبلية، ولها نظرية في الربط بين الديدان الشرجية لدى الاناث و التسبب ببعض الافرازات المهبلية الأثثية ، ويقول بعض المؤرخين الطبيين أن في كتاباتها من الروابط الطبية ما لا لا

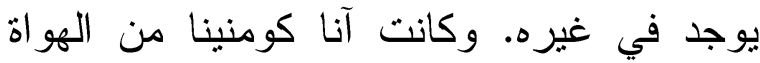
اللائي احترفن بالممارسة وليس بالدراسة، ومن

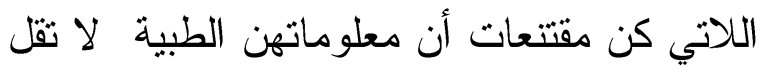
عن المحترفين، ومن الأمراض التي عالجتها النقرس، فكانت توصي بالتمرينات المنتظمة ومني درءاً للمرض، ولعلها في هذا الثأن اختارت أحسن آراء زمانها، ويدل وصفها الخارق في هي هذان

${ }^{45}$ Prioreschi, Pinio, A history of Medicine: Byzantine and Islamic Medicine, Horatius Press,

First edition, 2001, pp. 47-126. 
امر اض النساء اولاً وقبل كل شيء، ولكن في الواقع أن الطبيبات لم يقصرن ممارستهن على النى

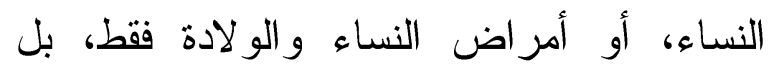
عالجن الرجال أيضاً؛ ففي باريس مثناً كانت

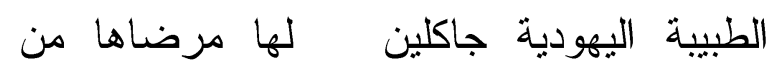

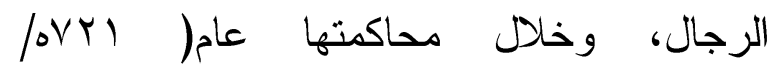

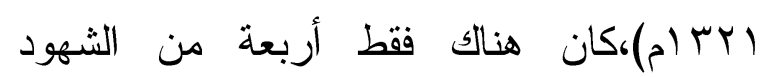

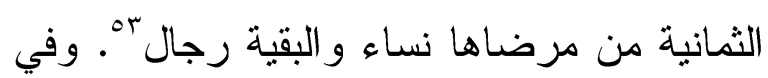
الوثائق الني تخص الطبيبة اليهودية ، وضي وهي طبيبة تحمل رخصة من إثبيلية، موقعة من

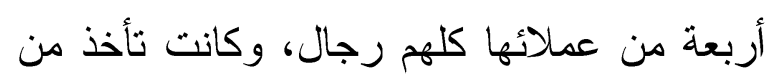

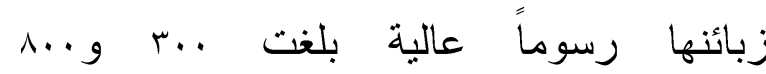

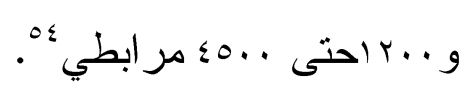

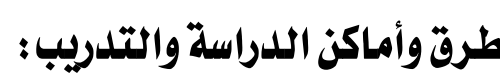

امتاز التعليم الطبي في العالم الاسلامي

بالمرونة، فليس هناك منطلبات محددة؛ إذ كان يجب على الطالب الالتزام بها قبل هبل البداء

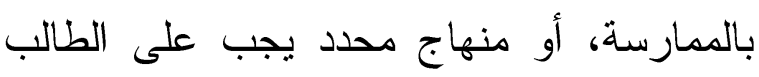

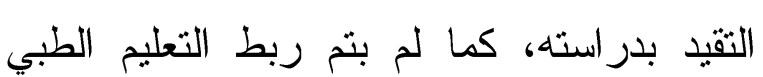

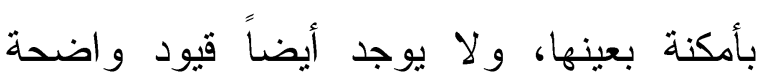
لتعريف المهنة، لذلك كان التعليم الطبي منوفر

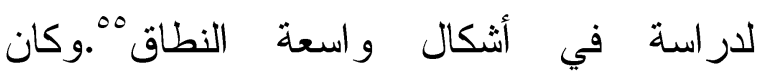
التدريب الطبي خارج المستشفى يتم في أي

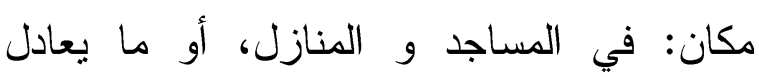

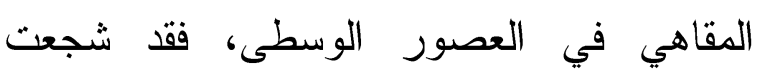

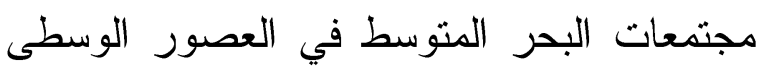

\footnotetext{
${ }^{53}$ Shatzmiller, Jews, Medicine, P. 110-111.

${ }^{54}$ Shatzmiller, Op.Cit, P. 110-111

55 Conrad, I. Lawrence, The Western Medical Tradition: 800BC to AD 1800, Cambridge university press .Fifth Edition, 2003, P.129.
}

العصور الوسطى المتأخرة تقلص شيئًا فشيئًا

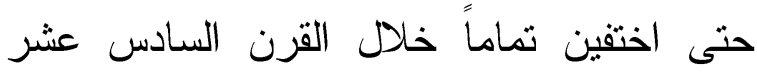
الميلادي|العاشر الهجري" 9؛، مما يدل على تأخر

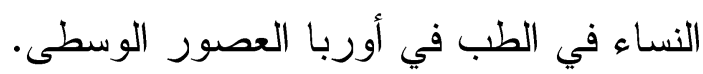
ويمكن ان نعد ايطالبا في ذلك الوقت أكثر

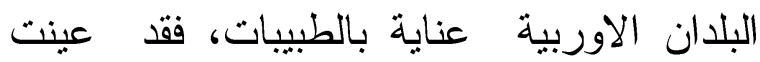

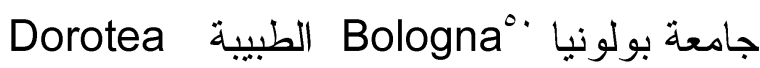
Bocch على كرسي الطب وفلسفة الأخلاق خلفاً

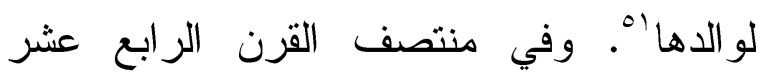
الميلادي كانت الطبيبة ربيكا Rebecca تعمل

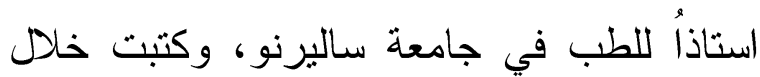

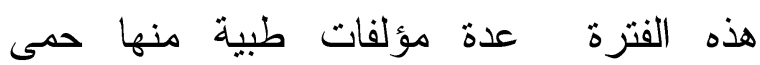
البول هن. نستتتج مما سبق أن إيطاليا كانت أكثر

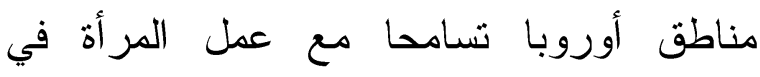

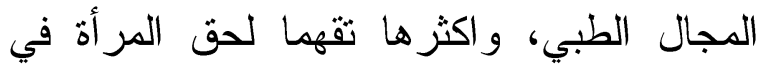
الانخراط في هذا المجال خاصة فيما يتعلق

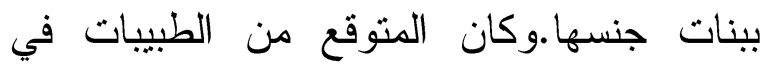
أوربا خلال العصور الوسطى التعامل مع من لئن

49 Applebaum, The concept of work ,p. 299.

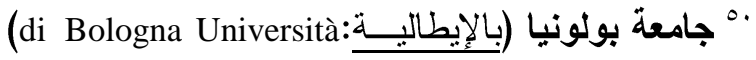

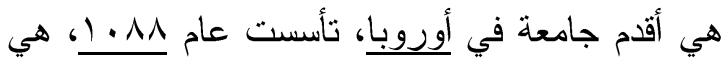

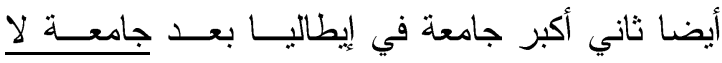

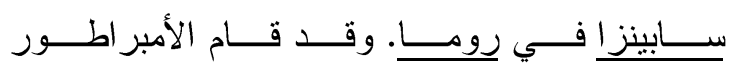

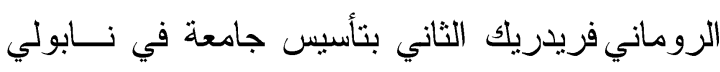

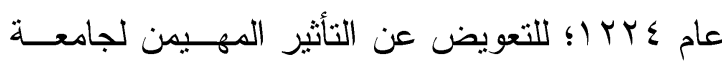

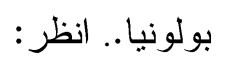
Johnson, P. (2000). The Renaissance : a short history. Modern Library chronicles (Modern Library ed.). New York: Modern Library, p. 9.

51 Olsen, chronology of Women's History, p.51. .

52 Olsen, Op. Cit, p.51. . 
بتفاصيل ما تتطلبه المهنة في الفحص و المعالجة، وكان مثل هذا التزمت أو ما يقرب منه مألوفا حتى لدى السيدات الإسبانيات اللاتي دخلن الإسلام بعد زواجهن من الفاتحين المسلمين

$$
\text { العرب (1) (1) (1) }
$$

لكن الواقع التاريخي يثبت غير ذللك،

وبشهادة المصادر الإسبانية نفسها، أن عدد الطبيبات المسلمات فاق عدد اليهوديات ناهيك عن النصر انيات، بل أنهن تغلغلن وسط الأسر النصرانية في الأندلس، وحظين بثة ملوك

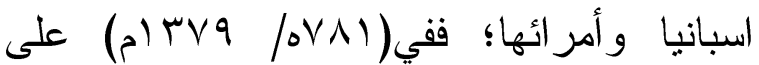
سبيل المثال رأى المحلفون الذين تم استدعاؤهم إلى منزل Francesco Monroc،فر انسيسكو مونروك أحد وجهاء بلنسية، أنه كان يتلقى الرعاية الطبية على يد طبيبة مسلمة، كانت تعالج قدمه المريضة، كما جاء في رسالتهم إلى بعثوا بها الحكومة" ، وسيتضح المزيد خلال البحث. ومهما يكن من أمر، فقد نصح الرسول باستشارة الأطباء، ولم يفرق بين الرجل و المرأة في هذه النصبحة. إلا أن المرأة المصون لـرن وحر ائر العو ائل و الأمير ات بقين مع ذلك يتمسكن بالخدر و الستر، ولم يخضعن للفحوص الطبية إلا لأيدي القابلات. و لا غر ابة أن يستسلم بعض هذه الفئة دن النساء ليد المولد أو الجراح حين تخطر حالتهن المرضية وهن بين حانقات وراضيات على كشف الطبيب الرجل أجسادهن. أما

${ }^{58}$ Spink and Lewis, Albucasis and Surgical Instruments, California University Press P. 421.

${ }^{59}$ M.Michal ,Luis. García Ballester ,Medical Licensing and Learning in Fourteenth Century Valencia, phladiphia, 1989, pp.30-32
المنهج الفردي في الدراسات العليا، وكان الطلاب يسافرون مسافات بعيدة لتحصيل العلم، وكان الطلاب المتدربون عادة ما بطحون لار اسة تحت إثر اف معلم مشهور أو في أوساط الطاب

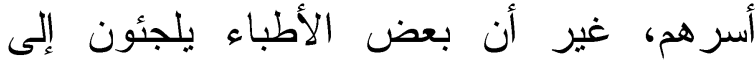
التعليم الذاتي لعدم قدرتهم على دفع أجرة المعلم. وكانت عائلة ابن زهر في الأندلس تقنخر بستة أجبال من الأطباء، لذلك كانت بنات بني زهر من النساء القليلات اللاتي حصلن على تدريب الأباء كلاسيكي في الطب ".كما تعد أساليب و أماكن التدريب في المجال الطبي في أوربا هي الاكثر من بين كل العلوم التجريبية، فقد يحصل الطبيب على الرخصة من السلطة السياسية المحلية أو لئن

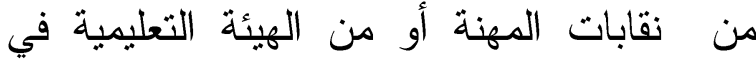
الجامعات او حتى الحكام المحليين، وقد يتلقى

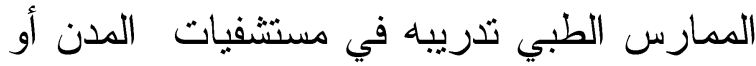

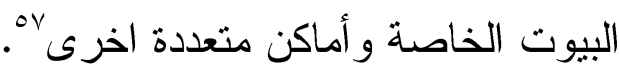

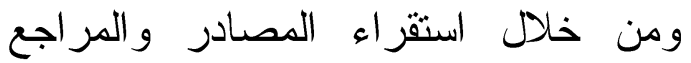
يتضح أن دراسة المرأة للطب في العالم

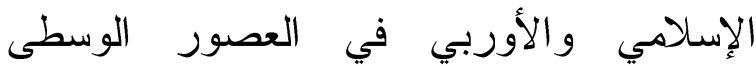
تدرجت و تتوعت بين عدة طرق و أساليب بهدف اكتساب المعرفة الطبية.ويزعم المستشرقان سبانك ولويس أن المرأة بحكم أنوثتها، و القيود العرفية و الثرعية التي تخضع لها المسلمة، قد واجتت صعوبة في دارسة الطب النسوي

${ }^{56}$ Miller, Kathryn, doctors without borders Medicine in the medieval 1 Mediterranean in History As Prelude: Muslims and Jews in the Medieval Mediterranean, edited by Joseph V. Montville, pp. $111-112$.

57 Withney, Medieval Science, p.32 
روهناك اثارات متعددة الى فريق مستقل من الطبيبات و المعلمات، وقد شهد علماء الطب بالدور المصبري الذي لعبه هذا الفريق هن

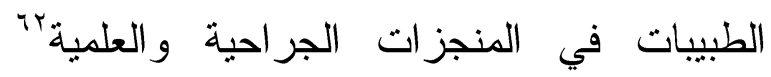
و أغلب الظن أن النساء اللاتي بسمين طبيبات في سالرنو كن قابلات تدربن في تلك المدرسة، فقد كانت النساء يدرسن القبالة و التمريض في سالرنو، وكان أكبر ما أخرجته مدرسة سالرنو الطبية رسالة في التوليد نشرت في القرن الثاني عشر المبلادي بعنوان " ترتولا و علاج أمراض

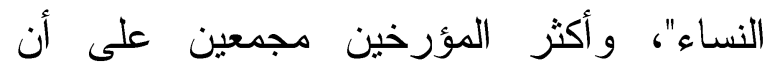
تروتو لا Trotula هذه كانت قابلة في سلرنو ". على كل حال تعد تزوتولا أشهر من درس في هذه المدرسة على الأطلاق، وكانت تمارس المعاينة السريرية على نطاق واسع، وتستخدم أدوات طبية لتحلل البول، وقياس النبض ، كما كانت تدرب طلابها على ثناثة أنواع من الأمر اض المعدية و الوراثية، وكان طلابها قادرين على التقريق بين التوفيئيد و الملاريا، وقياس درجة الحرارة وتقدير مدة شفاء

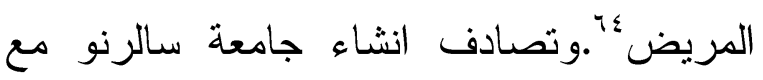
الحملة الصليبية الأولى التي بدأت في نهاية القرن الحادي عشر الميلادي. وإضـافة الى كونها

62 Ballester, Luis Grarcia, Practical Medicine from Salerno to the Black Death, Cambridge University Press, 1994, P.401; Brooke E, Women Healers: Portraits of Herbalists, Physicians, and Midwives, Rochester, Healing Arts Press, 1995,pp. 28-39. .

זٓ ديور انت، قصة الحضارة،، جVس، ص 9 • . 7. ${ }^{64}$ Brooke E, Women Healers: Portraits of Herbalists, pp. 28-39.
الطبيبات فليس لهن ذكر في التراثيات العربية، أو كن يعملن في الطب على مستوى القبالة أو

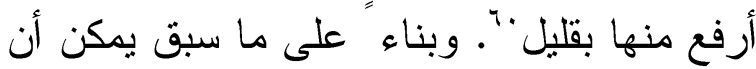
نميز بين ثلاث طرق رئيسة يستطيع من خلالها طالب الطب الحصول على دراسة الطب، و الحصول على المعرفة الطبية: - دراسة الطب في المستشفيات، حيث كان الطالب أو الطالبة يتذرب على مهنة الطب تدريباً عملياً، فيقضي وفته مع المرضى، ويتابع حالاتهم المختلفة، وتطورات أمر اضهه، و إلى جانب الدراسة العملية كان هناك الجانب النظري لدراسة الطب في المستشفيات، حيث إن معظم المستشفيات في العالم الإسلامي كانت تحتوي على قاعات

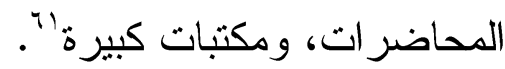
أما في أوربا، خلا القرن الحادي عشر الميلادي، فقد تم إقصاء النساء من الدراسة الجامعية، ولكن كان هناك استثناءات؛ فقد سمحت جامعة بولونيا الايطالية منذ تأسيسها

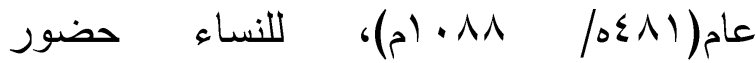
محاضر اتها كالذكور تماماً، كما أمتذ جو التشامح الذي كانت تعيشه سالرينو الى النساء الطبيبات مثلهن مثل العرب و اليهود، لذلك كانت جامعة سالرنو، هي الجامعة لوحيدة في أوروبا التي فتحت أبو ابها للنساء طيلة معظم فترة وجودها،

${ }^{60}$ Sink and Lewis, Albucasis , p. 421.

"יأبو بكر، أميمه و السعدي، هدى، النســاء، وهرنــة الطب في المجتمعات الإسـلامية، القــاهرة، مؤسســة المرآة و الذاكرة، طا، 999 (م، صمي . 
بعلاج أمراض النساء، وكذلك ابنته التي

يدعو ها البعض بالحفيدة بنت الحفيد، و ابنتها،

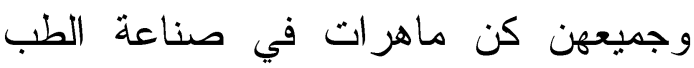
و المداواة، ولديهن خبرة ممتازة فيما يتعلق بالأمر اض النسائية"، وكذللك الأمر يقال عن بنت شهاب الدين أبي الصائغ رئيسة الأطباء

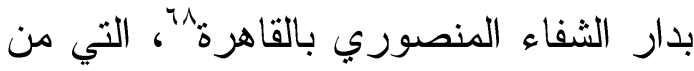
المؤكد أنها تلقت تدريبها وتعليمها الطبي على يد والدها رئيس الأطباء بالبيمارستان

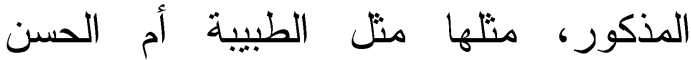
الطنجالي التي ساهم و الدها الطبيب أحمد بن منابن عبد اله الهاشمي الطنجالي في تكوينها الطبي .9.9.

ولم يكن حصول النساء على المعرفة الطبية محصوراً على بنات الأسر الطبية، فقد كان معظم النساء الطبيبات، يستقيدون من لطن محارمهن كآبائهن و إخو انهن في تعلم الطب ، فقد درسن أيضا على يد غير المحارم، فالطبيبة عائشة ابنة محمد بن الجيار محتسب مدينة سبتة

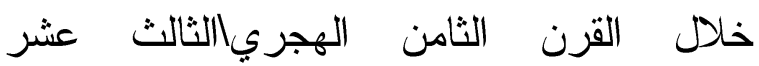
الميلادي، درست الطب على يد صهرها الطبيب المشهور الثريشي الذي عاصر السلطان أبي عنان المريني، واحتل مكانة مميزة عند الخاصة و العامة، وكانت عارفة بالعقاقير، وكذلك بالمباه

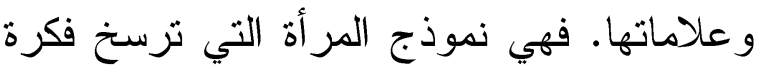
موسوعية الطبيب ونبوغه في معارف متعددة

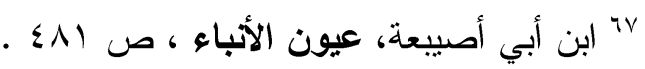

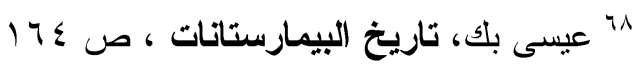

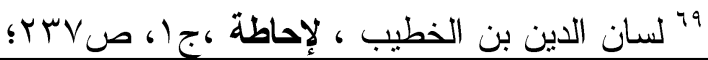

مركز ا تجاريا كانت محطة لعودة الصليبيين الى أوروبا الذين كان الكثير منهم من الجرحى و لابد أنهم خضعوا للمعالجة في كلية سالرنو الطبية ومن المحتمل أن ذلك تم على بد الفريق الطبي النسائي م".

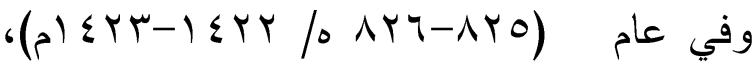
كانت كلية costanza calenda في جامعة نابولي أول جامعة تدرب النساء الطبيبات في التاريخ

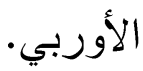
- التدريس الخصوصي: وهو أن يلازم طالب واحد أو طالبان على الأكثر طبيباً مشهوراً للتعلم منه، وغالباً ما يلازم الطالب أستاذه

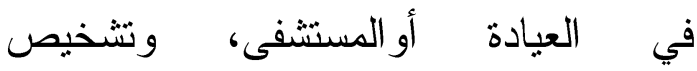

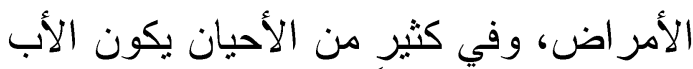

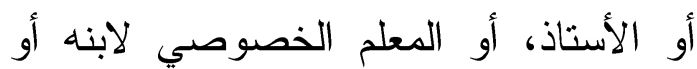
ابنته، حيث كان توارث مهنة الطب بين

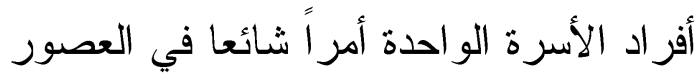

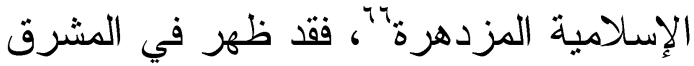
و المغرب الإسلامي وفي الدولة الأموية في الأندلس طبيبات شهيرات ينتمين إلى أسر الإلى علمية؛ فقد نبغت في أسرة الطبيب الثهير ابن زهر أربع طبيبات هن شقيقة الحفيد أبو لكئ بكر محمد بن أبي مروان بن زهر وكانت توصف بانها طبيبة مولدة، وابنتها كانتا عالمتين بالطب و المداواة ولهما خبرة كبيرة

${ }^{65}$ Ballester, Op. Cit,, PP.26-156.

${ }^{66}$ Dols, Michael, Medieval Islamic Medicine, California, University Of California Press, 1984, p. 36-38.

Prioeschi, Pinio, Byzantine and Islamic Medicine, Horatius press. Omaha, first ed. 2001p.p. 385-386. 
سارة وغير ها من الطبيبات دربن طالبات أيضاً: كما دربن طلاباً.

يتضح مما سبق أن التعليم الخصوصي للمهن الطبية كان ينت بناء على عقد بين المعلم و الطب، يحدد فيه مدة التدريب.أما في العالم الإسلامي لئي فكان تدريس الطبيبات لطلابها ومريديها ذكورا

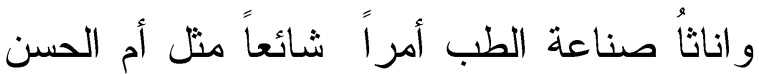

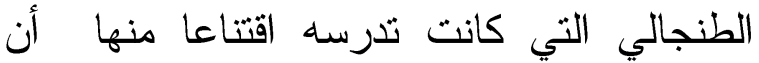
العلوم ومنها الطب يكتسب بالدرجة الأول عن طريق التدريب و الممارسة ومجالسة العلماء، وليس من بطون الكتب فقط ، نستشف ذلك من قولها:

\section{الخط ليس له في العلم فائســـــة}

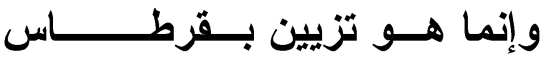
و الارس سؤلي لا أبغي به بدلًا

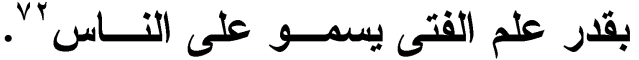
أضف إلى ذلك أن عدداً من الأطباء المشهورين درسوا الطب على يد النساء، كغلام الحرة زوجة المنضري حاكم مدينة شفشاون المغربية الذي تعلم الطب على يد قابلة، لم يحفظ اسمها، كانت عارفة بالحشائش و الأدوية، كما استعان الطبيب المشهور أبو القاسم الزهراوي بالنساء في معالجة مرضاه؛ إذ كان يقف خلف

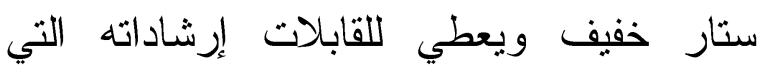
تتاسب الحالات العسرة و أغلب الظن أن هذاب

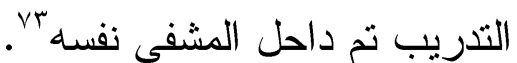

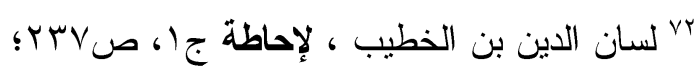

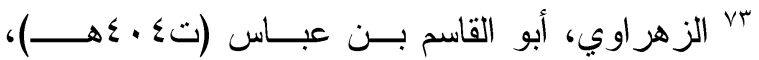

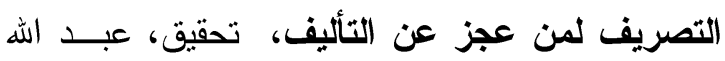

سواء كان ذكرا أم أنثى ، ولطالما أجازها الأمر اء بالهدايا و التحف. هذا يعني بأن صيتها فاق مسقط رأسها ليبلغ دار الملك آنذالك الحاضرة فاس، و إلى باقي حو اضر المغرب المريني، لأن ملوك بني مرين، وخصوصا منهم أبا الحسن و أبا عنان كانا يتنافسان في العمر ان ودعم العلوم و أهلها، فانتشرت في عهديهما البيمارستانات بكل ربوع مملكتهما، وازدهرت العلوم، ومنها العلوم الطبية. ولا ريب، أنها استفادت من بيئتها، و أفادت معاصريها ذكور ا وإناثا. فنقل العلوم من آنان. فرد إلى آخر ومن أمة إلى أخرى لا يتم إلا إذا كان هناك تقارب بين الأفراد والثعوب في مستوى الثقافة ونوعها، وقد ختمت الطبيبة عائشة مشوارها الدنيوي بصدقة جارية، إذ " عهدت بتوقيف ربعها في وجوه البر، سبيل

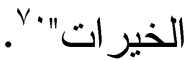
و كان هذا النوع من التدريس معروفاً في أوروبا في ذلك الوقت؛ ففي وثثقة تعود

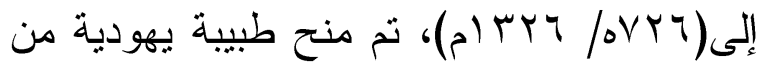
مارسيليا تسمى سارة، أرملة الطبيب أبراهام، رخصة تدريس الطب في أوربا في العصور

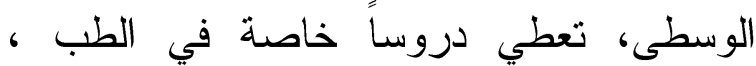
و هناك وثيقة تتحدث عن عقد اتفاق بينها وبين إحدى طلابها ، تعلن فيها مو افقتها على تدريسه

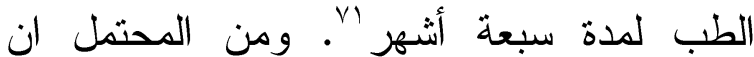
ابن عذاري، البيان المغرب فـــ أخبـار الأســلس V.

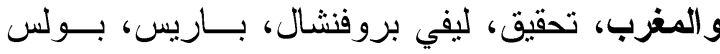

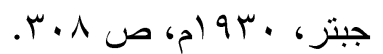
71 Olsen, chronology of Women's History, p.51. . 
الوقت.كانت المعالجات و الطبيبات اليهوديات، يكتسبن المهنة عن طريق التّرب على يد أحد

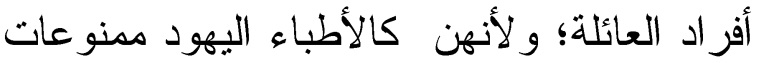
من دراسة لطب في الجامعات، وبعد التدريب يمكن أن بحصلن على رخصة لممارسة الطب من رؤساء الطائفة، على الرغم من صعوبة وندرة الحصول على الرخصة الرسمية ويحصل فقط في بعض الأماكن و التجمعات المحلية، إلا أن هؤلاء النساء يعتبرن طبيبات

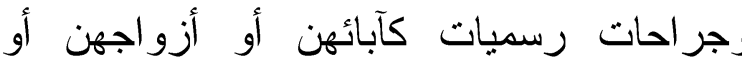
إخو انهن

وكان الأطباء و الجراحون الأوربيون

يعلمون بناتهم ويدربونهن على صناعة الطب حتى يخلفنهم في هذه الصناعة؛ لأنهن ممنوعات من الدراسة في الجامعات.لكن حدث تطور في بداية القرن الرابع عشر الميلادي ، عندما قامت

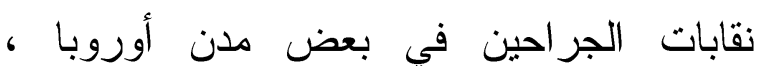
بالسماح لأبناء وبنات الأطباء والجراحين المنتمين إلى النقابة بممارسة المهنة.ويبدو ان ان الهاء بنات الاطباء لم يحظين بنفس القدر من التعريف كالأبناء الذكور، ويفهم من الادلة المنتاثرة أن مثل هؤلاء الطبيبات لم يكن يعرضن خدماتهن

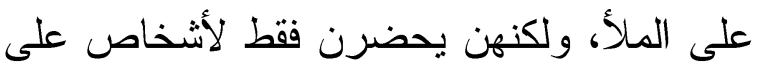
صلة بعوائلهن، كما أن النساء النبيلات اللاتي تلقين تعليما رسمياً، يشمل اللغة اللاتينية، وبعد النداه ذللك و اصلن دراسة اضافية في الطب ممن الكتب

${ }^{76}$ EmilyTaitz,Sondra Henry,Cheryl Tallan, The JPS guide to Jewish women: 600 B.C.E.- 900 C.E, Jewish publication society, America, 203, p. 88،
- - طريقة تعلم الطب بالممارسة و الخبرة العملية دون در اسة رسمية أو منهجية. اكتسبت النساء في صدر الإسلام الطب عن طريق الخبرة و الممارسة، إذ أن الدولة الإسلامي كانت لا تزال في طور التكوين، وكان الرسول

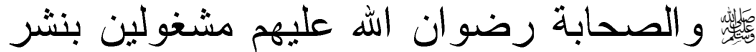
الإسلام، وتوطيد أركان الدولة الجديدة، فلم تكن هناك جامعات أو مدارس طبية، ومعظمهن

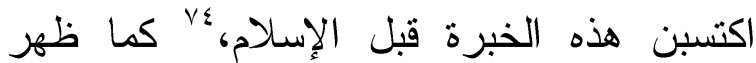
الكثير من النساء الجَراحات في العصر النبوي، ومن الواضح أن تخصصهن في الجراحة لم يأت عن دراسة كنهجية، و إنما جاء عن طريق الخيرة و الممارسة، نتيجةً لظهور الحاجة إلى من يعالج

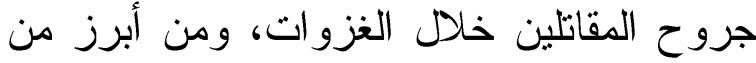
نبغ في هذا الدجال الربيع بنت معوذ الأنصارية، وآهنة بنت قيس الأنصارية، وسلمى أم رافع

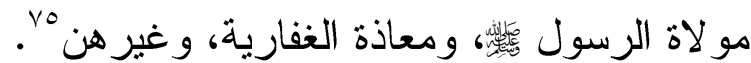

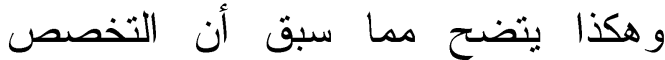
الطبي الذي برزت فيه نساء صدر الإسلام هو

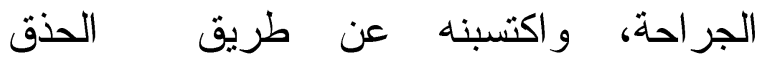
و الممارسة العملية، دون دراسة منهجية، أو تدريب في مستشفى، أو حتى على يد جراح

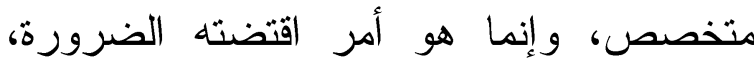
وفرضه و واقع الغزوات و المعارك في ذللك

عبد الرازق مسعود السعيد، الأردن، وزارة النقافــة،

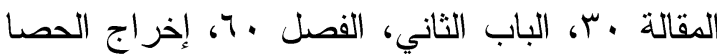

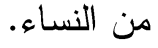
كء انظر فيما سبق: التمهيد لهذا البحث.

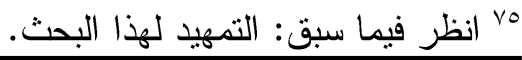


كبيرة من الطبيبات الأكاديميات و التجريبيات من اليهوديات. وتشكل القابلات المجموعة الأكبر من النساء المعالجات اللاتي لايهن إلى حدما تدريب

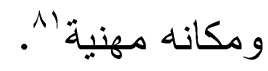

وفي المجتمعات الريفية كانت المرأة

الحكيمة (الكبيرة في السن)، تعد من هؤلاء المعالجين التجريبيين وهي متخصصة في استخدام الاعشاب المحلية؟^ما. وطبقا لما ذكرته نانسي سير ايسي حوالي 0 1. من أسماء الطبيبات المعروفات لدينا من شمال أوربا هن هني هنياء

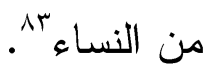

وكانت الأديرة مكاناً مهمًا لتعليم المرأة

المعالجة الطبية في أوربا العصور الوسطى، لما تتيحه هذه المجتمعات من فرصة المشاركة في الأبحاث، وخير مثال على ذلك الر اهبة الألمانية، التي تعد أول طبيبة ألمانية، وتتاولت في كتاباتها الخصبة مواضيع مختلفة كالطب و التاريخ الطبيعي، و علم النبات وظلت الر اهبات كغيرهن من رجال الدين يمارسن الطب حتى عام(سب00/ وبا (م)، لأن المستشفيات لم تكن قد ظهرت لمكن بعد، وكان الرهبان و الر اهبات الذين تعلموا اللغة اللاتينية كجزء من تدريبهم الديني، و استمروا بعد ذلك في دراسة ما استطاعوا من الكتب الطبية الموجودة في مكتبة الديرءء.

ومنذ القرن الثاني عشر حتى القرن

الخامس عشر الميلاديين سمح للنساء اليهوديات

${ }^{81}$ Withney, Op. Cit, pp. 31-32

82 Ibid, p.32.

83 , p.32. Ioc

84 Newman, Daily in the Middle Ages,p. 251.
وغيرها من المصادر حسب ما تسمح به الظروف، ومثل بنات الاطباء فإنهن لا يعرضن

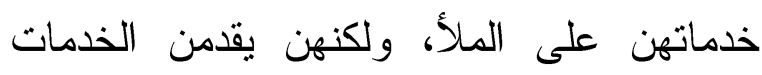
الطبية لعائلاتهن وللخدم والاصدقاء و المعارف ققط على كل حال يبدو أن اكتساب الطب

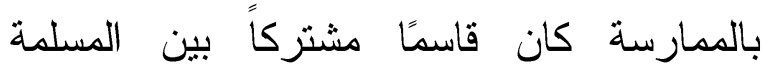

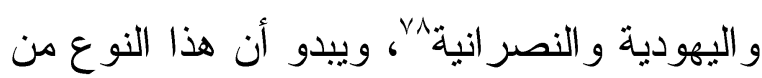
التدريب قد استمر لعدة عقود، فقد أظهرت وثائق الجنيزة أن عدداً كبيراً من اليهوديات مارسن الطب عن طريق الخبرة و الممارسة بدون دراسة رسمية أو منهجية في مدارس الطب أو حتى في المستشفيات. وهذا النوع من الطبيبات كن ينتمين

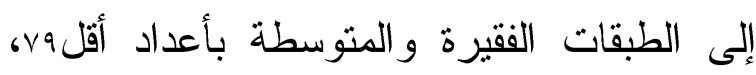
ولم نجد منهن من تحمل المسمى الجامعي الرسمي "طبيبة"، ولم نجد منهن من درست في الجامعات. وكانت اليهوديات يتلقين تعليمهن الطبي في العائلة، وبعد ذلك يقدمن للاختبار، فعلى سبيل المثال كان زوج زلطبية اليهودية هافا و ابنها جر احين.ويمكن أن نضيف إلى هذه الفئة الاطباء التجريبيين وهم ممارسون غير رسميين، وغير رخصين على الاطلاق، ويعتمدون بشكل كبير في تلقي المهنة على أسلوب المشافهة و المحاولة و الخطأ،؛ و ونسبة

77 Newman, Op. Cit, p. 251.

${ }^{78}$ Dean, Ruth, \& Thomason ,Melissa, Women of the middle ages, 2002 , p. 50

${ }^{79}$ S.D. Coition, Mediterranean Society, the Jewish Communities of Arab World as Portroyed in documents of the Cairo Genizah, 4 vols. Univ. of California, Press 1967 - 1978., Vol. I, p. 128.

80 Withney, Medieval Science, p.32. 
المشفى قبل توليها رئاسته احتمالاً كبيراً، كما بها: وقد تدربت النساء العربيات في دمشق في العديد من بيمارستانات دمشق التي بلغت ستين

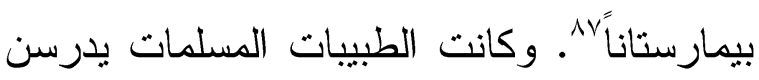

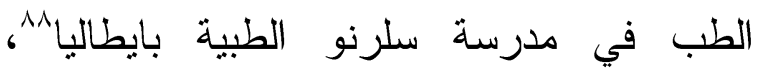
خاصة و أن العديد من أعضاء الهيئة التعليمية من لهن لهنية الأطباء المسلمين 19. و على الرغم من أن الرازي مارس الرازي القبالة على الحامل مباشرة، وبواسطة القابلة أيضا"، ، إلا أنه يفهم من كتاباته أنه لم يكن يفحص بنفسه على الأعضاء الأنثوية في المرأة لأسباب تقليدية أو نفسية وأنه كان يسأل القابلة أن تفحص عليها بعد أن يُرشدها إلى طريقة

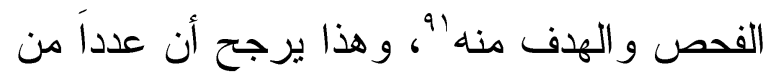
القابلات و المعالجات تدربن على يد الرازي في البيمارستان، وكان الطبيب الأندلسي الزهراوي كالر ازي في حرصه على الاستعانة بالممرضات عند إجراء عمليات جراحية للنساء لتوفير الأمن و الطمأنينة لهن، مع تزويدهن بالإزشادات

${ }^{87}$ Levin, Beatrice, Women and medicine, The Scarecrow Press, London, Third edition, 2002, p. 68.

${ }^{88}$ Maintain, Peter and Pulley, Richard, Medicine Through the ages, Cheltenham, England, Stanly Thorens publisher, Second edition, 1997, p.79.

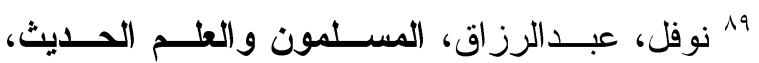

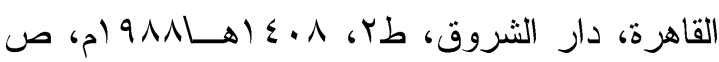

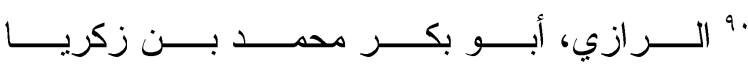

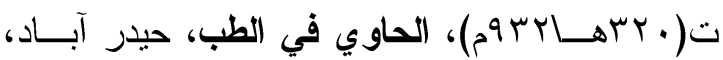
( )
بالدراسة في الجامعات و المدارس الطبية في أوربا. كما كانت المستشفيات في الامبراطورية البيزنطية هي المكان الذي ت تتلقى فيه الطبيبات

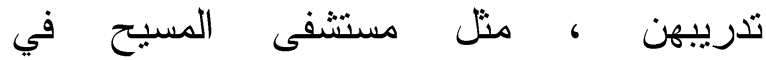
القسطنطينية، حيث يوجد مدرس للطب في كل جناح إلى جانب الأطباء، وكانت علية تدريس الطلاب مبادئ الطب الاساسية، وكان يأخذ مقابل

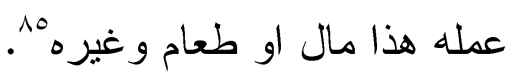
ويبدو أن الطبيبات المسلمات كن على دراية تامة بطرق معالجات كافة الحالات، فقد شرح شرف الدين بن علي خلال القرن التاسع الهجري الخامس عشر الميلادي في كتابه طريقة معالجة الطبيبات للخنثى به. و لا يعني هذا أن طبيبات العصور الوسطى لم بحظين

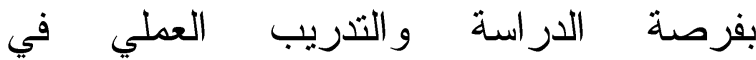
المستشفيات، و التذريس فيها كالرجال تماماً، خاصة بعد انتشار المستشفيات في العالم الإسلامي خلال العصور الوسطى، فعلى الرغم من أن المصادر الإسلامبة لم تذكر ذلك مباشرة، إلا إن وصول ابنة الطبيب شهاب الدين بن الصائغ إلى منصب رئاسة الأطباء في المستشفى المنصوري، والذي يتضمن الأشر اف على أطباء المشفى رجالا ونساءً، يجعل احتمال در استها في هذا المشفى على يد و الدها، وغيره من أطباء

${ }^{85}$ Byzantine Monastic Foundation of the Surviving Founder, Typike and Testment. N,28, Pantocrator, p.p 757-758.

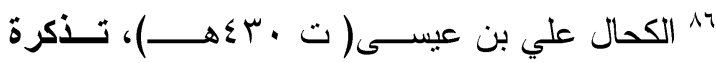
الكحالين، مخطوطة في مكتبة جامعة الملــك ســعود، . 
حول استمرار تداول أطباء تلك المرحلة لمؤلف أبي حنيفة الدينوري الخاص بالنبات، الذي يعد لثال

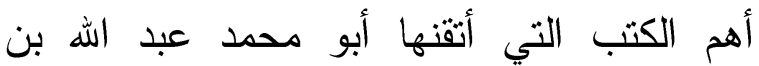
الحفيد أبي بكر بن زهر خلال القرن السادس

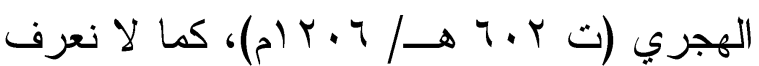
مدى استفادت الطبيبة عائشة من كتب ابن البيطار وعلى رأسها كتاب "الجامع لمفردات الأدوية والأغذية"، و، ولا شك أن كتب علماء النبات وسائر الأطباء كان رائجاً عهر الطبية الأنه عائشة وبعد ذلك بالدواضر الكبرى المغربية،

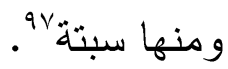
و هكذا يتضح مما سبق تتوع طرق و أماكن الدراسة و التّريب للطبيبات، و العاملات في المهن الطبية، وتطورها تدريجيا خلال العصور الوسطى، وأنها لم تكن متشابهة تماماً بين العالم الإسلامي و الأوربي.

المكانة الاجتماعية القيود وموقف الأطباء

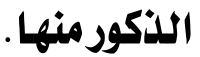

حظيت الطبيبات و المعالجات في العالم

الإسلامي بالاحترام والثقدير، فلم يكن اشتغال

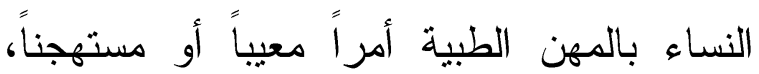
فمن اللحظة الأولى التي بدأ فيها ميلاد أول دولة النة إسلامية على يد الرسول الكريم لئل في المدينة المنورة، و المر أة المسلمة تمارس الطبابة بمختلف لرست

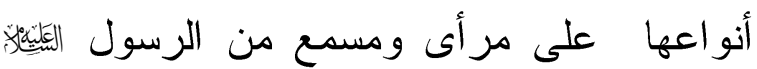

ب99 بالكامل (البضاوية)، نساء طبيبـات فــي المغــرب

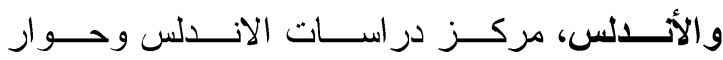
الحضار ات، الرباط، كلية الأدب و العلوم الانسانية.

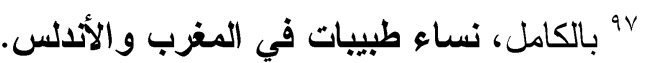

اللازمة لكل حالة"ج". مما يدل على تطور طريقة دراسة المرأة في العالم الإسلامي للمهن الطبية، وأن هذا النوع من التدريب كان مقبو لاً ومعروفاً في العالم الإسلامي، ولم يكن فيه غضاضة، بل كان محل تشجيع خاصة وأن وجود نساء

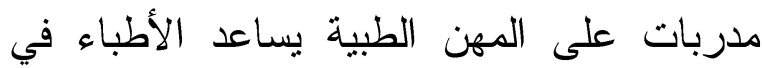

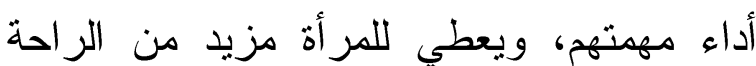
و الطمأنينة. "داء مهنه"

وفي حين كان الأطباء الذكور في العالم الإسلامي يرتدون الأثو اب الحريرية، والمعاطف الاطباء الامستق ذات الأكمام الواسعة، و العمامة الملونة،

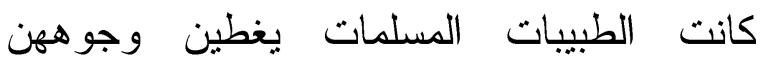
بالحجاب، ويلبسن ثوباً أسود يغطيهن من الرأس وجنات

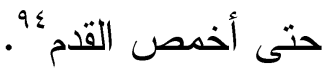
ويبدو أن كتاب القانون لابن سينا كان أبرز

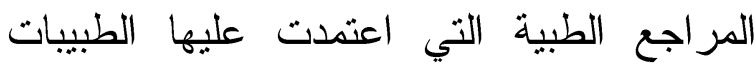

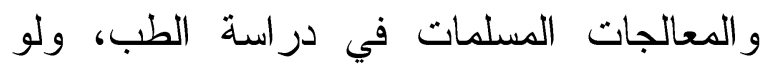
أخذنا المغرب الإسلامي كمثال، لوجدنا أن كتاب ابن سينا كان هو المعتمد خلال عصر الطبيبة عائشة سالفة الذكر 90 من لان الأطباء المعاصرين لها، وكانت هي نفسها عارفة بالعقاقير، فلا شك أنها استفادت من ذخائر الكتب الطبية، و على رأسها كتب المفردات الطبية التي كانت تجارتها رائجة، إلا أننا لا نجد أدنى إثارة

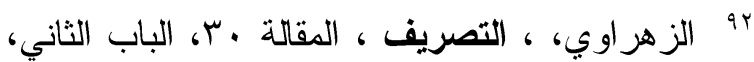
الفصل • جا، إخر اج الحصا من النساء.

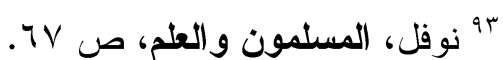

94 Levin, Women and medicine, p. 69. 99 انظر فيما سبق: الندريس الخصوصي من هذا البحث. 
دون أن ينكر عليهن ذلك، فقد ظهر الكثير من و المعالجات مثل القابلات والمختصات نساء الصحابة كرضوان الله عليهر- في صفوف بالأمر اض النسائية، عبابة جارية الخليفة القتال يضمدن الجرحى ويسقين العطشى، وكان الأموي يزيد بن عبدالملك ب.1 وفضل جارية

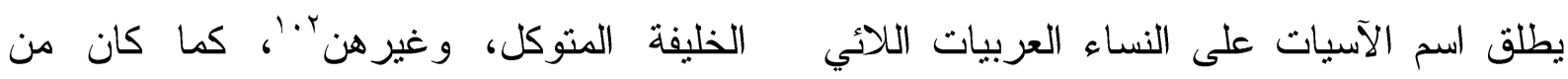
يعملن في تضميد الجراح، وجبر العظام والوقاية الشائع عمل النساء في العهد السلجوقي في مهنة من النزف، وكن يسرن إلى المعارك مع الرجال التمريض و التوليد، ومن المرجح أنهن لعبن دوراً جنباً إلى جنب، حاملات أواني الماء وما يحتاج هاماً أساسياً وجوهرياً في علاج الجنود الجرحى و المصابين بسبب كثرة حروب السلاجقة و غزو اتهم. وقد جنت بعض القو ابل ثروات طائلة من وراء تولبدهن لزوجات الأمراء و المتتفذين

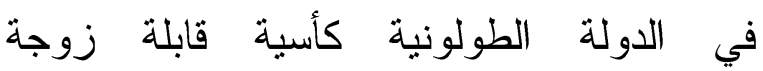

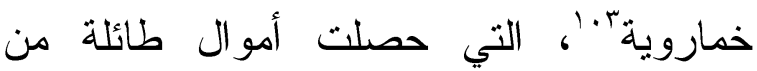

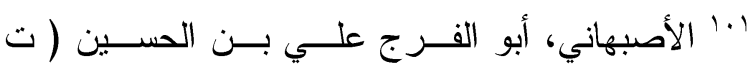

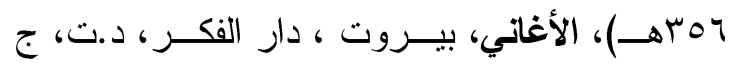

$$
\text { 10 } 10
$$

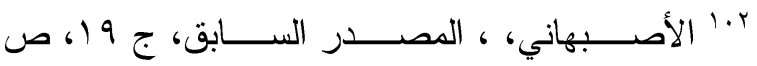

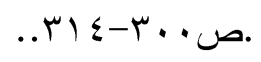

r.1 صاحب الديار المصرية بعد أبيه سنة إحدى وسبعين

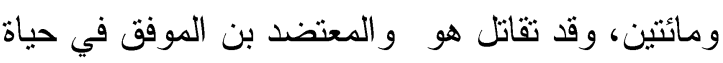

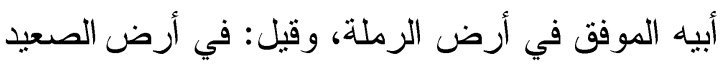

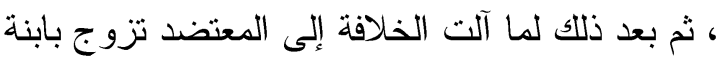

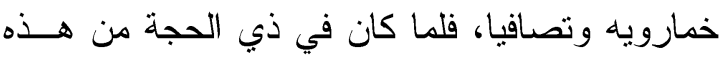

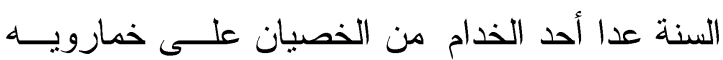

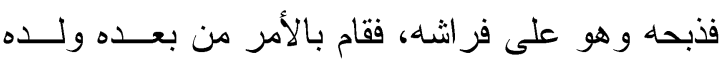

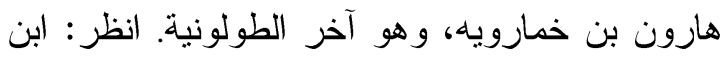

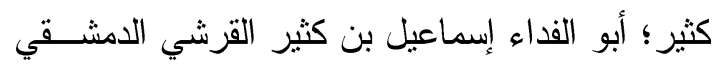

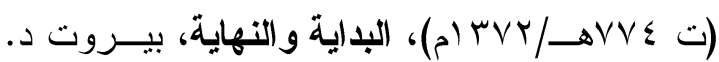

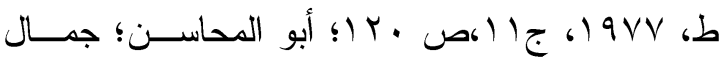

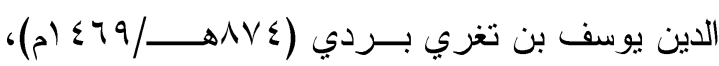
إليه الجريح من اللفائف و الجبائز وغير ذلك وكنَّ ينفذن بين الرجال مسعفات معالجات^هُ، وقد أجاز الشرع هذا العمل وحببه إلى النفوس، فقد نص الإمام أحمد على أنه يجوز للمرأة أن تخدم الرجل ونشاهد منه عورة في حال المرضه" . وقال منت هذا القول الإمام المحدِّث الحافظ

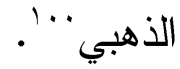

ولا يبدو أن النظرة إلى المرأة الطبيبة، أو المعالجة في العالم الإسـامي قد شابها شيء من الدونية بعد العصر النبوي وصدر الإسلام

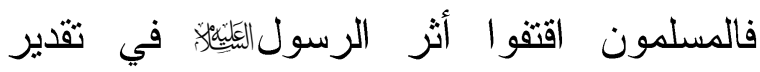
الممارسات للمهن الطبية، خاصة عندما تكون ما تقدمه من خدمات خاصة ببنات جنسها، فقد امتلأت قصور الأمر اء ورجال الدولة بالطبيبات

هو ياسين، عبد اللطيف، فضل أطبّاء العرب على أوربّـا

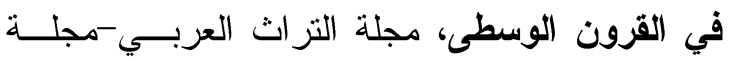

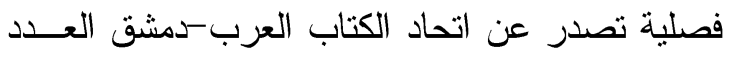
- OV جمادى الأولى 10 10 النه 10. 99 في حالة عدم توفر رجال للقيام بهذه المهمة.

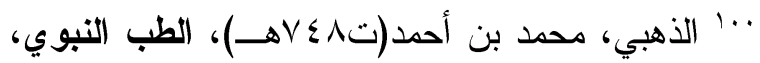

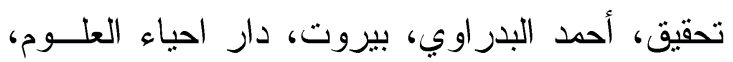


و الصيت الذائع و و الاتصال العلمي و التبادل الثقافي `•. ومهما يكن من أمر فإن هذه المكانة

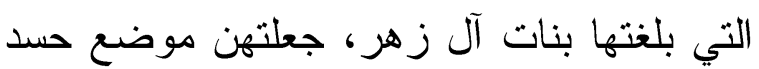

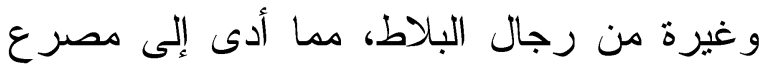

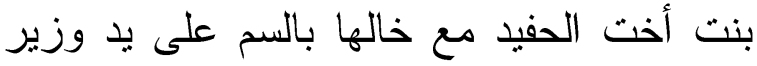

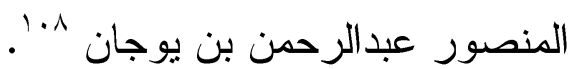
ومما يعكس نظرة الاحترام والتقدير التي حظيت بها الطبيبات والمعالجات في العالم الإسلامي خلال العصور الوسطى، إثادة العلماء و المؤرخين بهن في مؤلفاتهم، فعندما تحدث ابن الإناهي أبي أصيبعة عن زينب طبيبة بن أود، وصفها

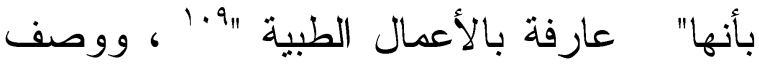
بنات آل زهر بانهما" عالمتان بالطب و المداواة

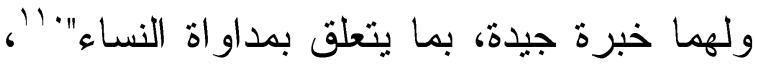
كما أثناد صاحب كتاب " بلغة الأمنية" بالطبيبة

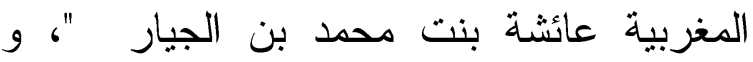
وصف المؤرخ المغربي ابن عذاري جارية الطبيب أبي عبد اله الكناني بقوله:" لم ير في

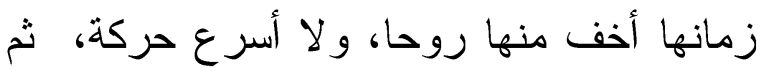
يصفها بــ "المعرفة بالطب، و وعلم الطبائع، ومعرفة التشريح وغير ذلك مما يقصر عنه

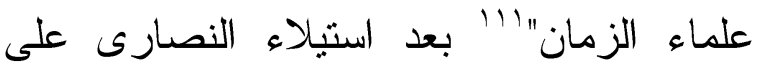

${ }^{107}$ Miller, Kathryn, doctors without borders Medicine in the medieval 1 Mediterranean in History As Prelude: Muslims and Jews in the Medieval Mediterranean, edited by Joseph V.

Montville, p. 112

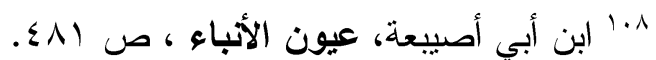

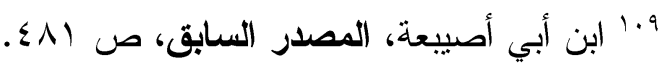
.

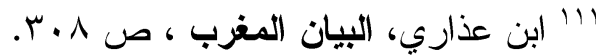

كونها القابلة الرسمية لزوجته، وبلغت المكانة التي وصلتها بعض القوابل تصدر ها لقضاء حوائج الناس و التوسط لهم عند الأمراء؛.'. و احتلاث بنات آل زهر مكانة مرموقة في البلاط الموحدي، فلم يكن المنصور أبو يوسف بعقوب بن يوسف بن عبد المومن الموحدي 1.1 لمداو اة نسائه و أطفاله و إمائه إلا أم العلاء بنت أبي مروان عبد الملك بن زهر أخت الحفيد التي تعلمت الطب على يد و الدها وتميزت في الو لادة و أمراض النساء، وعندما توفيت احتلت ابنتها مكانتها في القصر، وكانت كو الدتها ماهرة في التوليد، وتعلمت الطب على يد والدتها. وكان المنصور الموحدي لا يقبل أحداً لنساء قصره إلا هي و أمهاج"'. . و المعروف أن للعمل في بلاط بلاط الخلفاء مز ابا عديدة منها الراتب الثابت

محمد حسين شمس الدين ، دار الكتب العلميــة، طاه

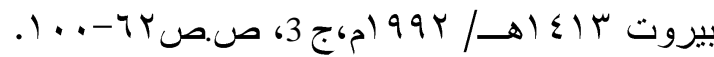
؛.' ابن الداية ، أحمد بن يوسف الكاتب(ت • ع اهــــ)، كتاب المكافاة وحسن العقبى، حققه وشرحه محمــود شاكر، بيروت، دار الكتب العلمية، ص VTI ا-، ـ I. ×11 هو المنصور أبو يوسف يعقوب بن يوسف بن عبــد المومن الموحدي، ثالــث خلفــاء الموحــدين بــبلاد المغرب، خلف و الده أبا يعقوب بن يوسف، حكم مـن

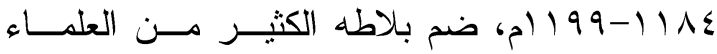
و الفلاسفة والفقهاء، وفي عهده انتصر المسلمون على

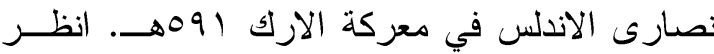
عنه: ابن خلكان، شمس الدين أحمد بــن محمــد ( ت (1/7هـ)، وفيات الأعيان وأنبــاء أبنــاء الزمـــان، تحقيق، إحسان عباس، بيروت ، دار صادر، د.ت ،

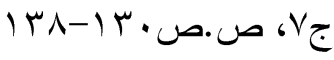

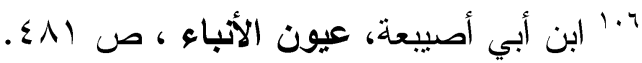


و الاعتر اف بالقيمة العلمية و العملية الذي حظيت بها المعالجات في العالم الإسلامي، أن الرازي أثهر أطباء القرن الرابع الهجريا العاشر الهري

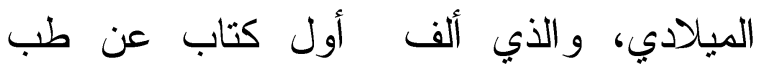
الأطفال، استعان بالنساء لمساعدته في وصف الحصبة و الجدري الكاذب، فكان أول طبيب فرق بين الأمر اض المعدية التي تتميز بالبثور والطفح الجلدي، ويتضح من خلال كتاباته تعاطفه مع الطبيبات، فقد اعترف بأنه أخذ علم الأعشاب عن امرأة، و لاحظ أن الطبيبات يكتفين باستخدام جرعات صغيرة من الدواء، عكس زملائهن الذكور الذين كانوا يبالغون في حجم الجرعات المستخدمة في العلاج، كما وصفهن بأنهن يتمتعن بحس إنساني وعاطفة أكثر من الذكور كما شجع الجراح الأندلسي الزهراوي في القرن الرابع الهجريالعاشر الميلادي وجود طبيبات مدربات، و اثاد بأهميتهن في اكتمال المعالجة الطبية، وذلك عندما اعترف بالصعوبة التي يواجهها الأطباء الذكور عند إجراء تللك العملية على المريضات :"علينا إما أن نجد طبيبة تعلمت الطريقة، أو طبيباً مخصياً يمكن اعتباره زميلاً أو قابلة يمكن إعطاؤها تعليمات حول

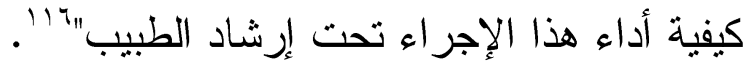
ويتضح من خلال قراءة كتب الأطباء المسلمين

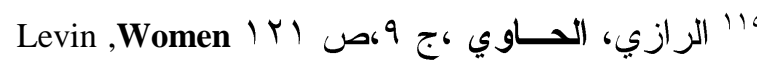
and medicine, p. 69; 1/4 الزهر اوي، التصريف ، المقالة ، بـ، الباب الثـاني، الفصل • جا، إخر اج الحصا من النساء.
الأندلس، استمر الأطباء المسلمون و اليهود في ممارسة الطب، وحصلوا على التزاخيص الطبية، واستعنت بهم العوائل المسلمة و النصر انبة على السواء، كما عرفت الطبيبات المسلمات بالخبرة و المهارة في علاج أمر اض العيون والقدم و البدين وغيرها من أعضاء

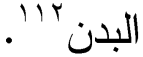
ومنذ نهاية القرن الثامن وبداية القرن التاسع الهجريين/ الرابع عشر وبداية القرن الخامس عشر الميلاديين كان هنالك طلب كبير في بلاط ارغون على الطبيبات المسلمات و اليهوديات، فعلى سبيل المثال اجتذبت مدينة كاستيلون (م) Castellon خدمات الطبيبات المسلمات نتيجة للنجاح الكبير الذي حققته في علاج أمر اض العيون ؛' '. وقد رظيت الطبيبات، وغيرهن من صاحبات المهن الطبية في العالم الإسلامي، بالتقدير و التشجيع، ولم يتعرضن للمضايقة، والإقصاء الذي كانت تعاني منه نظيراتهن المعالجات و الطبيبات الأوربيات من زمالئهن الذكور، ومما يؤكد هذا التشجيع، التقدير

112 Smith, A History of Personal Hygiene, p. 31. "r/ مدينة اسبانية ضمن منطقة بلنسية، تقع شرقي شـبـه الجزيرة الأيبيرية على ساحل ازهار المتوسطي. حمت المدينة خلال العصور الوسطى خنادق مائية واســـوار و ابر اج، وبنيت فيها كنيسة، أصبحت كاتدر ائية. انظر :

Kern, Robert, The Regions of Spain: A Reference Guide to History and Culture, Greenwood Press, 1995 , p. 339.

114 Solomon, Michael, The Literature of Misogyny in Medieval Spain, the Arcipreste de Talavera, p. 149 
بقدرتها و أهليتها لممارسة الطب كالرجل تماماً، لذللك حرصو ا على تدريب وتعليم جو اريهم الطب و التشريح حتى تفوقت بعضهن على الرجال،

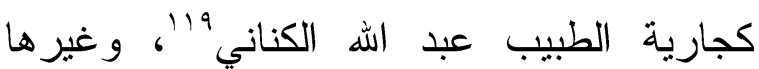
كثير r' ، ، وهو على النقيض تماماً من موقف أطباء أوربا، الذين قللوا من قدرات المرأة،

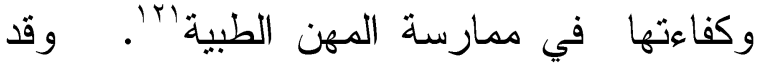

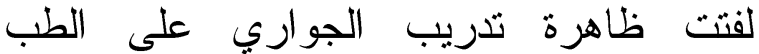
و الجراحة في العالم الإسلامي خلال العصور لإل الوسطى السير ريشارد بوربون، فذكر في كتابه الذي ألفه عن قصة " ألف ليلة وليلة" عن جواري العرب العارفات بالطب و التشريح و الجراحة، فذكر أن إحداهن عندما امتحنها الأطباء، تمكنت من معرفة العروق التي ينزف منها الدم، كما عرفت ترياق السموم بَr'. ومهما يكن من أمر فإن هذا يعطينا فكرة عن الأشياء التي كان يتعلمها طلاب وطالبات فركات الطب في ذلك الوقت، كما تدل على أن النساء درسن الطب، وبرعن فيه.

وزعمت بعض المراجع الأجنبية أن المعالجات المسلمات عانين من هجوم بغيض، وغبر أخلاقي من رجال النخب الطبية، الذين

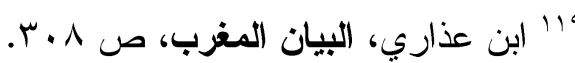

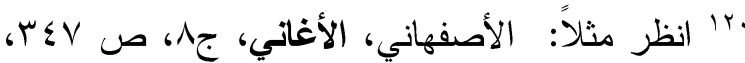
121 Furst, Women Healer, p. 57

rri مؤلف مجهول، ألف ليلة وليلة، ، بيروت، مكتبــة

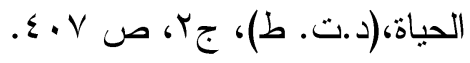

Burton, Richard, The Arabian Nights: Thousand

Nights and A Night, London, The Burtun, Club, 1885, V. v, pp. 189-245; Levin, Women and medicine, p. 69
حرصهم على الاستعانة بالنساء لمساعدتهم في الكثف على المريضات وتقديم الرعاية الطبية

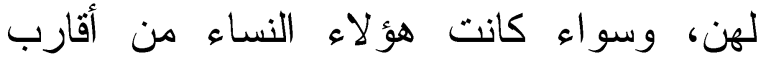
المريضة نفسها أو ممرضات معينات في لهاء لهن البيمارستان، ومما يؤكد أيضا بعد الطبيبات و المعالجات في المجتمع الإسلامي عن هذا النوع لئان من التنافس غير الثريف مع الأطباء وجود روح التعاون بين الطرفين في المجال الطبي، فكان ابن سينا مثناً يستعين بقطرات للعين تصنعها

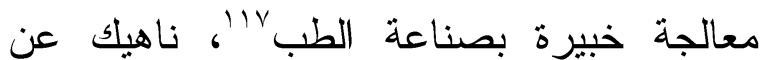
استعانته بقريبات المريض لمساعدته في بعض بهض

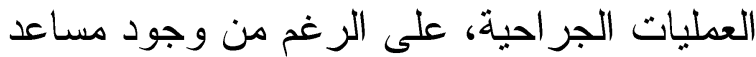

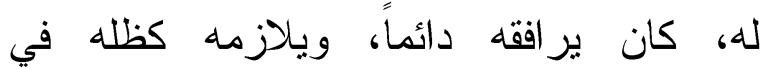

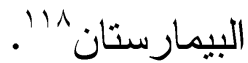

وهكذا بتضح أن علاقة الطبيب المسلم بالطبية المسلمة كانت علاقة تكامل وتبادل للخبرات، بعيداً عن روح الاحتكار، و المصالح

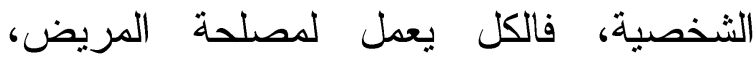
وخدمة المجتمع، وهذه الروح كانت غائبة تماما في علاقة الطبيب النصراني بالطبيبات و المعالجات في أوربا العصور الوسطى. ومما ينفي النظرة الدونية للمرأة المعالجة و الطبيبة عند الأطباء المسلمين أيضاً، أنهم آهنوا النهاء

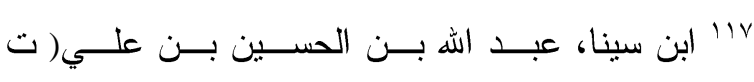

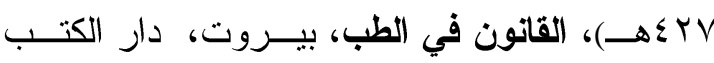

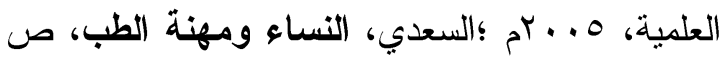
.11

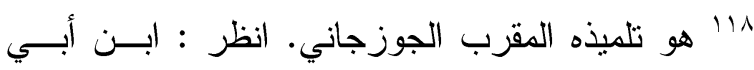

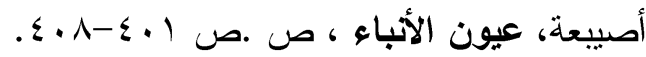


ألفو ا مؤلفات بتهمون فيها المعالجات بالدجل الرجال، وحرب من الكنيسة والسلطة المدنية، خاصة إذا كانت ناجحة في مهنتها كما حدث لــــ (Jacqueline Felicie D’Almanis

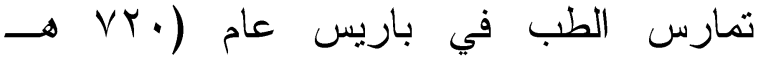

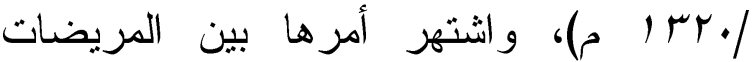
اللاتي بفضلن أن تفحصهن طبيبة وليس طبيباً، وكانت تصنع أدويتها الخاصة، ونجحت نجاحا كبيرا في علاج العديد من الأمراض، وهذا النجاح الذي حققته أثنار غضب أطباء ومدرسي الطب في جامعة باريس؛ لذلك حاولو ا منعها من مزاولة مهنة الطب وعلاج المرضى، بحجة أنها لا تحمل شهادة جامعية في الطب، أو رخصة رسمية لمزاولة مهنة الطب، وأمروها أن تهجر الطب، ولكنها تجاهلت هذا الأمر، و استمرت في

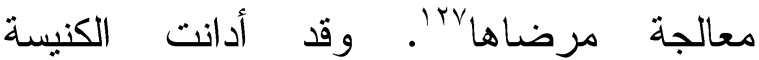
الكاثيولكية والمجتمع الأبوي في العصور الوسطى النساء المعالجات بسبب تأثنرهن الكبير في المجتمع، وجدت النساء أنفسهن ضحية لأعمال وحشية غير مبررة، مثل تعذيبهن حرقهن على الألواح، لأن المجتمع اعتبرهن ساحرات ، وقد بدأت هذه الظاهرة في قلب أوربا، وسرعان ما انتشرت في دول كثيرة من العالم، وكاد الاعتقاد بوجود الساحرات يكون عاماً في ذلك الوقت، وكان من المعتقدات المنتشرة أن النساء يستطعن أن يؤدين ويقتلن

بنظرة من عيونهن الحاسدةمى ا.

${ }^{127}$ Eliot, Lynne, Medieval Medicine and plague, New York, USA, Crabtree Publish company, 2006,p. 27.

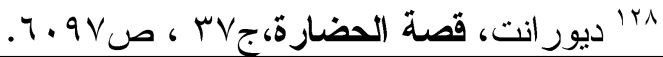
و الغش و عدم الكفاءة'r' ،كالهجوم الذي تعرضت

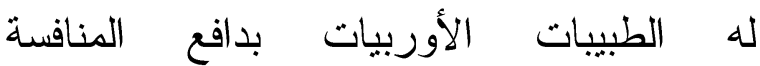
الاقتصاديةء'. و الحقبقة أن الانتقاد في العالم الإسلامي اقتصر على الاخلاء على مهنة الطب الطب الإنى سواء كانو ا رجالا او نساء، ممن لا بملكون

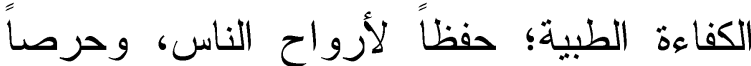

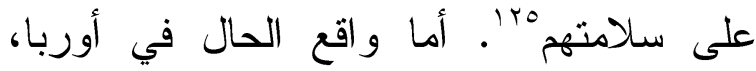

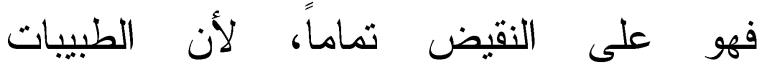

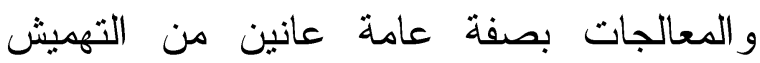

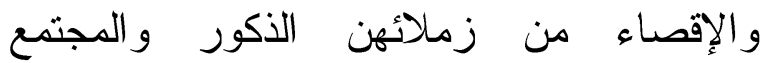
و الكنيسة و السلطة الحاكمة، حتى لو كن يتمتعن

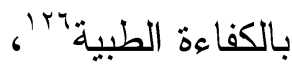
وكانت النظرة إلى المرأة الطبيبة في

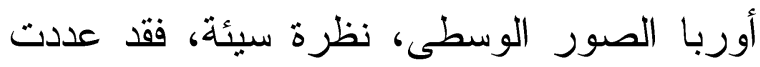
العديد من النساء ساحرات لمجرد أنهن على لئى درجة عالية من المعرفة بالطب و الجر احة، وكان القتل و التعذيب أحد أساليب الكنيسة لقمع المعرفة بله و العلم لدى النساء، والذي اعتبرته شر وخطر

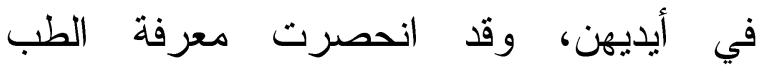
وممارسته في أفقر الطبقات، خاصة النساء، اللاتي نسب أليهن الكثير من المكتشفات العلمية،

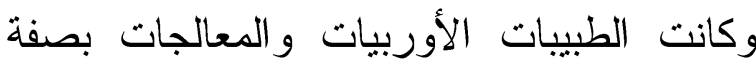
عامة يتعرضن لمنافسة شديدة من الأطباء

$$
\text { rri ابن أبي أصيبعة، عيون الأباء ، ص. •وس. }
$$

${ }^{124}$ Smith, Bonnie G, The Oxford Encyclopedia of Women in World History : 4 Volume sets, Oxford University Press, Oxford, 2008, p. 433.

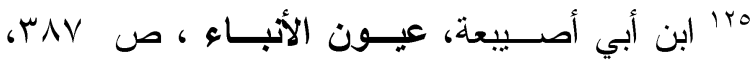


و التقدير، التي سطرها المؤرخون في حق الطبيبات المسلمات، الطبيبات و المشتخلات في المهن الطبية في أوربا هدفاً للهجوم في نصوص القرون الوسطى مثل: القصص الثعبية الإيطالية المسماةr'Tistun Erec" جوم دي روج Jaume de Roig، خاصة كتابه الشهير، و الموسوم بــ"كتاب المرأة" في القرن الخامس عشر الميلاديالتاسع الهجري، ودعا في كتاباته إلى التمبيز بين المعالجين الإكلنكبين و الأطباء غير المرخصين، وهذا التقريق ظهر بوضوح في كتابه المذكور أعلاه، ويرى في هذا الكتاب أن المرأة ببساطة تتقصها الكفاءة للعمل في فنون المعالجة، فهي تميل بطبيعتها إلى قلب

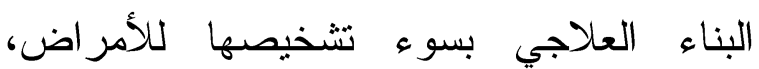
وسوء تطبيقها للعلاج، ويرى أيضًا أن المرأة التي تعمل في المجال الطبي هي موضع شكـَّاء. شك بr". ومن المحتمل أن روج قد بنى تصوره عن المر أة المعالجة، بسبب الطريقة الخاطئة التي تلقت بها زوجته نعليمها الطبي على بد بد بلي

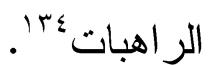

أما الطبيبات البهوديات فكن محترمات وسط طائفتهن، حيث ذكر جواتين أن الطبية شخصية محترمة ومحبوبة في المجتمع ولها تأثثر إيجابي على الطبقات الفقيرة التي تنتمي

132 Furst, Women Healer, p. 57.

133 Roig, Jaume, The Spill O Libre de les Dones, Madried, 1990, pp. 842-856, 910-916; Furst , Women Healer, p.p 80-83, 87 .

134 Furst, Op. Cit, p. 87. Roig, The Spill O Libre, pp. 842-856, 910-916
وفي القرن الرابع عشر أصدرت الكنيسة مرسوماً، بأن أي امرأة تمارس الطب دون در اسة علمية، فهي ساحرةه با،كما منعت المرأة في أوربا من ممارسة معظم أشكال العلاج لأنهن غير قادرات على الدراسة في الجامعات وبالتالي لن يصبحن مؤهلات للحصول على رخصة المزاولة، ولكن ذلك لم يمنع الكثير ات منهن من لمن تقديم الرعاية الصحية خاصة في امر اض النساء وطب التوليد، كما استطاع عدد آخر كسب ثقة الأمراء و المتتفذين في الدولة، و أكثرهن من

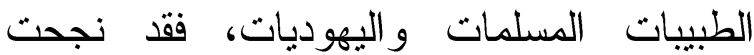

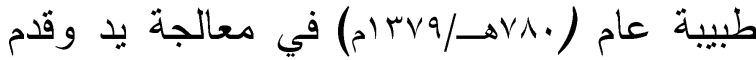
شخصية هامة في بلنسية، هو فرنسيسكو مونيكو،

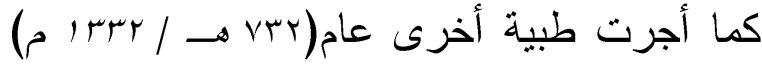
جراحة ناجحة في البيت الملكي في مملكة بلنسية'” 'ومما بجدر ذكره أن حدة التهميش والاقصاء للمرأة في أوربا عن المجال الطبي زادت مع تزايد عدد الجامعات، بالإضافة إلى المطالبة بالحصول على رخصة لمزاولة مهنة الطب، ولكن احتياجات سكان المدن لخدمات الطبيبات جعلهم يغضون الطرف عن مثل هذه القيود'"'.وهكذا نجد مقابل كلمات الإطراء

129 Matilda Joslyn Gage, Woman, Church and State: A Historical Account of the Status of Woman through The Christian Ages, With Reminiscences of the Matriarchate, second ed, New York, The truth ceek Company, 1893, p. 136. لعل الكنيسة أر ادت بهذا المرسوم أن تحد مــن عــدد المشعوذات ومدعيات الطب، وبهذا المنظور يمكن أن نعد ذلك خطوة إيجابية.

${ }^{130}$ Furst, Women Healer, p. 57

131 . I $\vee \leqslant$ Medieval Means Girls, p. 


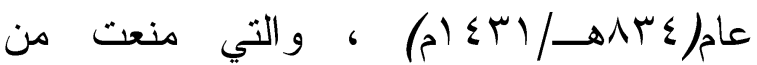
اقراض مال بالربا، على افتراض انها تجني أمو الا من ممارستها لطب، كما تعد الطبيبة سارة ورتزبورج من الطبيبات اليهوديات النابغات في أوروبا و حصلت في r مايو سنة من الأسقق جون الثاني أسقف برون على إذن بممارسة الطب في كل الأبرشية التابعة له، وقد دفعت إنت بندان مقابل الحصول على هذا الإذن فلورينين، وعشر فلورينات للضر ائب، وبعد عشرين يوما حصلت على وثيقة موقعة من المحكمة تمنحها ملكية كل ار اضي فون ريديرن Friederich Von Riedern وكانت بعض اليهوديات يعملن غي خدمة العائلة المالكة مثل Na Floreta canoga التي كانت

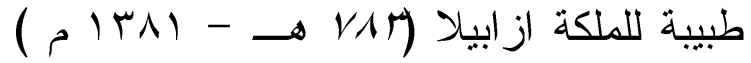
في بلنسية في النصف الثاني من القرن الرابع عشر الميلادي وقابلة يهودية تعالج زوجة الملك لكي

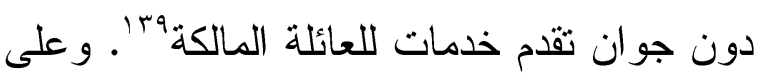
الرغم من الكنبسة حرمت على اليهود تدريس

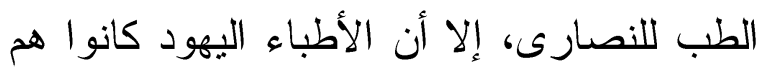
المسيطرين على حرفة الطب، حتى إنهم تولوا مناصب عالية في البلاط البابوي، فالطبيبة

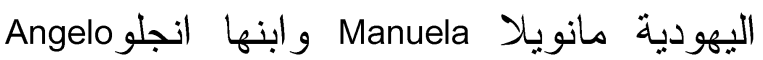

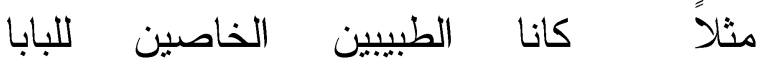
بنفكيشسBonifacius IX، وكان لهما سمعة طيبة

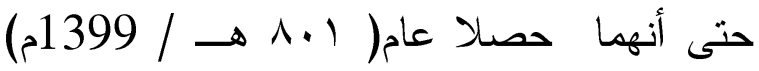
على اعفاء من الضرائب، وقيل ان مانويلا و ابنها كانا متحمسين لمساعدة الفقر اء و البائسين،

138 Tallan, , Doctors, p.6

139 Tallan, Op,Cit, p.6.
إليها وتخدمها، وكان يطلق عليها لقب " طبيبة"، وهي صيغة تصغير توحي بالحب و التذلل مما يدل على مكانتها الخاصة بين أفراد المجتمهمبا، و انخرطت العديد من اليهوديات في أوربا في مهنة الطب، ولم تقتصر معالجتهن على النساء فقط بل شملت الرجال أيضاب"rا'. وطبقا لنتائج التي توصلت لها الباحثة اليهودية Cheryl Tallan "، فإن المرأة اليهودية، كانت تتلقى نفس التدريب الطبي الذي يتلقاه الطبيب اليهودي، كما عالجت نفس المرضى الذين كان يعالجهم، وفي حين أن بعض المناطق التي بقطنها اليهود خلت تماما من الطبيبات اليهوديات، ففى مناطق أخرى بلغت

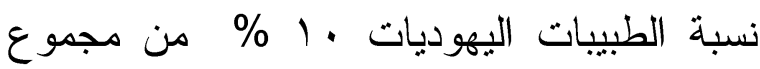
الأطباء اليهود، ولم يحققن فقط نجاحا في مجال، كان غالب رواده من الرجال، لكنهن شكلن جزءأ لا يتجزأ من الجماعة اليهودية العاملة في

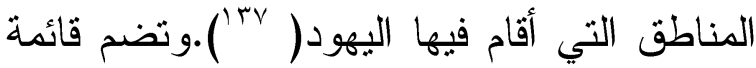

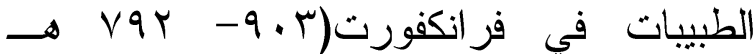

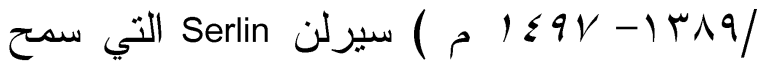
لها بالعيش مع مواطنين نصارى خارج الحي اليهودي، وطلبت من البلدية اعفاءها من فن الضرائب على اساس كفاءتها وشعبيتها لكن مجلس البلدية رفض طلبها، وقد تكون هي نفسها التي تم

${ }^{135}$ Goitien, Mid. Society, Vol. I, p. 128.

${ }^{136}$ Olsen, chronology of Women's History, p. 57 .

${ }^{137}$ Tallan, Cherylr, "Doctors: Medieval." Jewish Women: A Comprehensive Historical Encyclopedia. 1 March 2009, p.6 . 
في العلن أو السر. وقد ميز اليونان بين القابلة

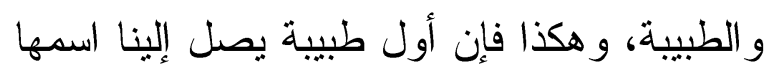
هي Phanostrate التي كتب على قبرها "طبيبة

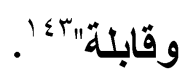

وسمح للمرأة ما بين القرنين الأول والسابع الهجريينا السابع والثالث عشر الميلاديين بممارسة مهنة القبالة. وقد أتاح إعفاء ها من الخدمة العسكرية الفرصة لدراسة العلاج و القبالة. وكانت شؤون القبالة و أمر اض النساء فرعاً أو فنا من فنون الطب الممارس قي ذلك الوقت، و عندما تطور لقب " القابلة" أو المولدة إلى داية عرفنا مؤرخين باسم" ابن الداية"، الذي كتب عن أخبار الأطباء، أي أنها كانت مهنة معروفة يعتد بها في المجتمع، و الدليل على مكانة

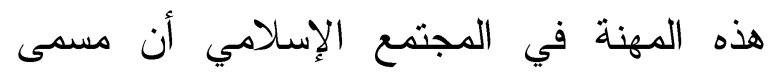

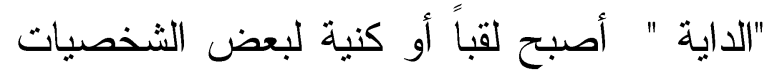
المعروفة في التاريخ، ولو كانت هذه المهنة مما تعاب بها صاحبتها لتورع أبناؤها عن حمل هذا

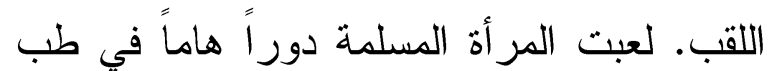
النساء و التوليد،وذلك كما يقول ابن خلدون في مقدمته الثهيرة: "صناعة التوليد صناعة يُعرف بها العمل في استخر اج المولود الآدمي من بطن أمه... وهي مختصة بالنساء في غالب الأمر بما

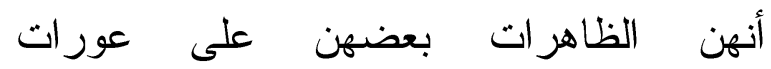

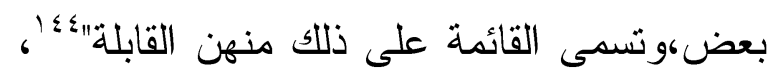

${ }^{143}$ Fuster, Women Healer And Physicians, p. 131

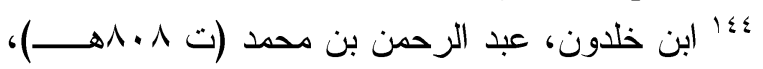

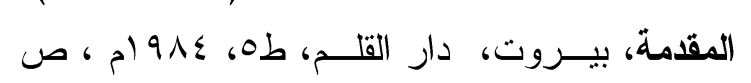

ولا يضغطان في دفع الأجرة، كما كانا يمتلكان خبرة فائقة في مجالهما.؛ '.

أنواع المهز الطبية التي مارستها النساء خلال

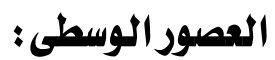
لم تثوان المر أة المسلمة عن المساهمة في الخدمات الطبية، وكان على رأس الخدمات التي برزت فيها المرأة التمريض والإسعاف الصحي في السلم و الحرب. وكان التمريض أبرز المهن الطبية التي مارستها النصرانيات في أوروبا، وكان العديد من النساء اللاتي ينتمين إلى الطبقات الدينية سواء كن راهبات أو مساعدات راهبات يؤدين الخدمات التمريضية كجزء من عملهن الديني اء'، ومن أهم أنواع التمريض لهودين الديني الذي ظهر في أوروبا نظام "الر اهبات الصالحات " ، كما ظهر في القرن الثاني عشر لري أثناء الحروب الصليبية نظام التمريض في الجيش، ويعرف بـــ "نظام الفرسان بالقديس سان خون" -فرسان القديس يوحنا (جون)- في القدس وكان لهذا النظام فروع مختلفة فى جميع البلاد

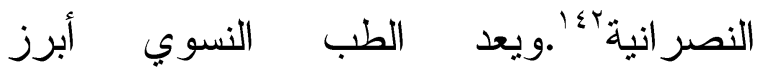
الاختصاصات الطبية التي برزت فيها المرأة يشمل حالات الو لادة بنوعيها الطبيعية و العسرة،

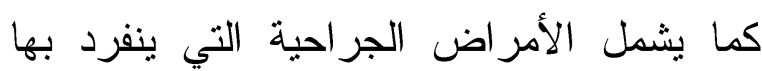
جسم المرأة دون الرجل .لذلك كانت القبالة في العصور الوسطى هي النشاط الطبي الرئيس للمر أة، ولكن كان هناك طبيبات ماهرات يعملن

140 Ibid,p.6

${ }^{141}$ Newman, Daily Life in The Middle Ages,p.266

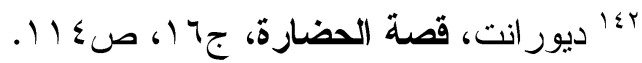


و عد ابن خلدون مهنة التوليد من أمهات و الخبرة9؛'، ويمكن أن ندرك أهمية المهارة الصنائع؛ لأنها “شريفة بالموضع، وضرورية في والخبرة في مثل هذه المهنة من وصية الرازي

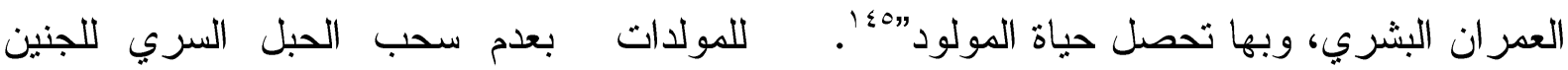

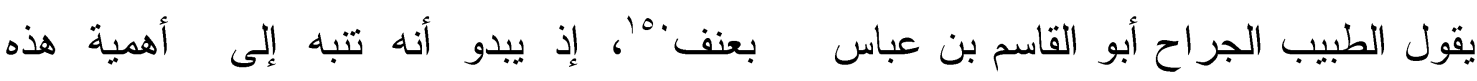

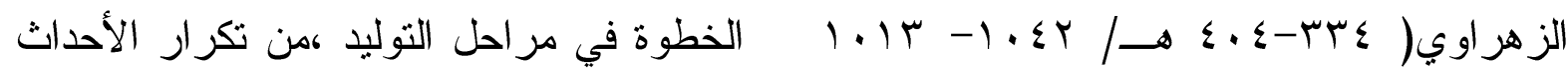
م) في كتابه التصريف لمن عجز عن التأليف : المفجعة التي تقع بسبب سوء تدبير استخلاص (ينبخي أن تتخذ طبيبة محسنة، فإن عدمتها المشيمة بيد القوابل القليلات الخبرة، فإنا نتوقف عند قوله (عدم سحب الحبل السري بعنف). فاطلب طبيباً عفيفاً، .. وتحضر قابلة محسنة في وقد وصف لنا ابن الداية طريقة عمل القابلة المسلمة، فذكر أنها كانت تمسح جوف الحامل وتتنظر حتى يأتيها المخاض، فتجلسها على كرسي الولادة الذي كانت ثتم عليه عملية الو لادة بسهولة، و هذا الكرسي من أهم مستلزمات الو لادة في العصور الإسلامية والوسيطة، وكانت كل داية في تلك الفترة تملك مثل هذا الكرسي، وترسله إلى بيث المر أة الحبلى قبل أن تذهب هي

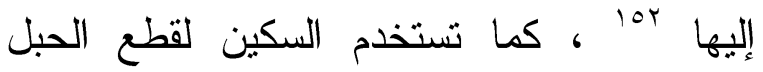
السري للمولود بor . ويعتقد الدكتور السامرائي أن هذا الكرسي كان يومئذ من أدوات الترف

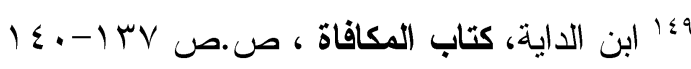

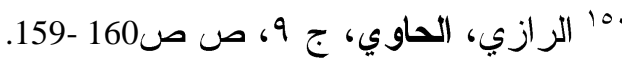

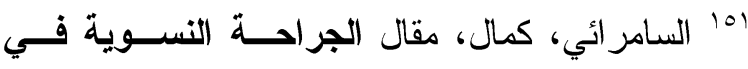
العصور الإسلامية، في موقع أثر العلمـــاء المســلمين على الجر احة و النتريح.

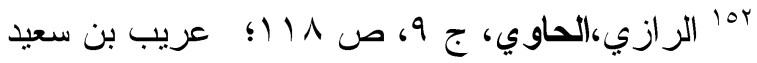
القرطبي، خلق الجنين وتدبير الحبالى والمولــودين،

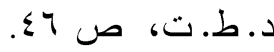
ror ابن الحاج، أبو عبد الله بن محمد العبدري الفاسـي ( 0؛ ابن خلدون، المصدر السابق، ص 0. . ع.

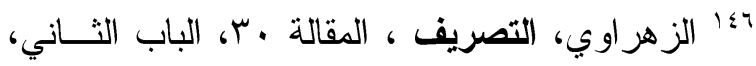
الفصل • جا، إخر اج الحصا من النساء.

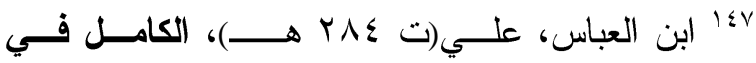

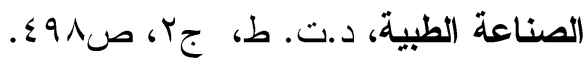

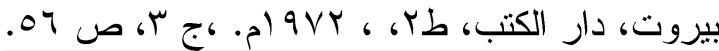
أمر النساء، .. وتأمر ها أن تصنع ما تامر به من

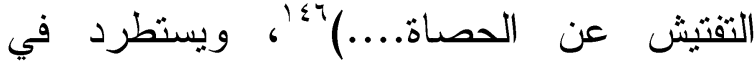
المقالة الثلاثين من الفصل الرابع و السبعين قائلاً في: في الفصل الرابع و السبعين في تعليم القو ابل كيف يعالجن الأجنة إذا خرجوا من غير الشكل الطبيعي)، ويعلم علي ابن عباس القابلة كيف تتصرف في حالة دوت الجنين: ( ينبغي أن تقدم على علاجها بأن تأمر القابلة أن تلقيها على ظهرها على السرير ... ثم تفتح بعض النساء فم الرحم، ورقبته، ... وأنه ينبغي أن لا تدخل السنار ات التي يخرج بها الجنين في عينيه أوفي

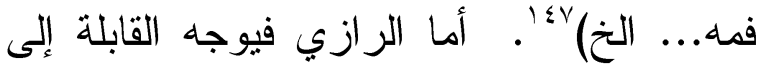
كيفية معرفة الحمل: قل للقابة تجس عنق الرحم

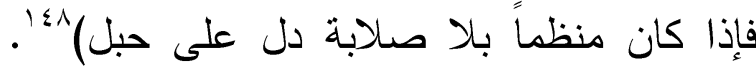
وكانت مهنة القبالة تتطلب قدر اً كبير من المهارة

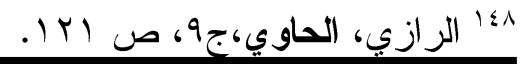


يشعرن بالر احة بفرك مرهمًا على بطونهن، وبتشجيعهن بالكلمات خلال عملية الولادة، وبعد خروج الطفل، فإنهن يقطعن الحبل السري، ويغسلن الطفل بالماء، وينشفنه بقطعة من لون القماش، ويلففنه بإحكام في عصابة من الكتان، وهذا بجعل الطفل يشعر بالدفء، و البعض يعتقد أن ذلك يساعد عظام الطفل على النمو بشكل صحيح، ثم يضعنه بجانب سرير أمه، ويتأكدن

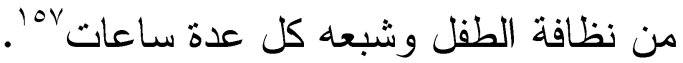
ويمكن أن نعد الولادة القاتل الأول للنساء في أوربا العصور الوسطى، فقد كان العديد من النساء يمتن بسبب العدوى أثتاء الولادة، أو له استتز اف كميات كبيرة من الدم 101، ونستتج من ذلك قصور الرعاية الصحية للحامل، خاصة إذا عرفنا أن المعالجات بصفة عامة كن يتعرضن لاضطهاد شديد من الرجال 109. و اعتبرت الو لادة في العصور الوسطى حدثاً مميتا؛ لذلك طلبت الكنيسة النصرانية من الحوامل إعداد أكفانهن والاعتراف بذنوبهن استعدادًا للموت. وأثارت الكنيسة إلى سفر التكوين 17: ب ،كأساس للألم في الولادة، حيث تلقت حو اء العقوبة عن دور ها في معصية الله كما يزعمون- و أنه "ضاعف الأحزان خاصتلك، و المفاهيم خاصتلك : في الحزن سوف تتجبي

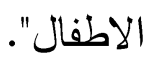

${ }^{157}$ Eliot, Lynne, Medieval Medicine and plague, New York, USA, Crabtree Publish company, 2006,p. 26.

${ }^{158}$ Eliot, Medieval Medicine. 26.

${ }^{159}$ Derirde, English, witches, midwives, and nurses: A history of Women Healers Feminist Press, second Edition, Ny, pp.4-12
وسمات الثراء فلا يستعمل إلا في البيوت الموسرة، وربما كان لكل عائلة كرسي خاص تتباهى بحسن صناعته، ثم اختفى بمرور الأزمان فلم ييق لله وجود في أواخر القرن التاسع الهجري/ الخامس عشر الميلادي، ورجعت الماخض تجلس القرفصاء على عادة جداتها السابقات في مضارب الصحر اء ؛ُ1. وكانت القابلة المسلمة تستعين بالدعاء و الأذكار لنسهيل عملية الولادة، مما يدل أنها كانت تجمع بين العلاج الحسي و الروحي، وهو ما كان الأثر الكبيز في نجاحها في مهنتها، وتقليل نسبة الوفيات بين الحبالى 100-بإذن الهه-. وكانت القابلات في الغالب يكتسبن خبرتهن من خلا تجارب الحياة، في عام (TIT) هـ/ع اب/ م) طلبث السلطات من المرأثين اجلنتينيا وبيرونا، أن تفحصا امرأة تعرضت

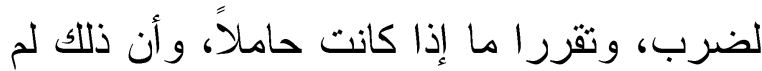
يؤد إلى خسارة جنينها، وعندما سئلت قابلة اخرى كيف عرفت المدة التي تلازم فبها سرير المخاض، اجابت ان ذلك بناء على ما راته وسمعته، فهي نفسها أم لخمسة ابناء، وشاهد العديد من النساء في المخاض 104. ولا يختلف عمل القابلة الأوربية عن عمل القابلة المسلمة، وكانت عملية الولادة تتم في غرفة الأم. فكانت القابلات يجعلن الأمهات

أع السـامر ائي ، الجراحسـة النســوية فـــي العصــور

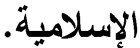

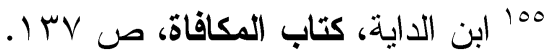
156 Green, Documenting women Doctors, pP. 348349 


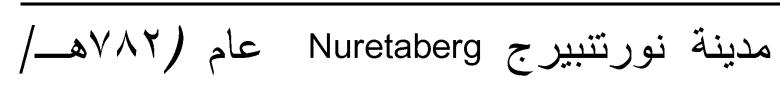
ایمس (م): بتعيين قابلة مهمتها الاشر اف وتدريب القوابل الاخريات، وعرف هذا المنصب باسم قابلة المدينة 17 .

وكانت المنافسة شديدة بين القابلات في

احتكار قبالة عائلة من العوائل في المجتمعات الإسلامية . وكانت أحداهن إذا دخلت بيتاً وقبلت فيه، لا يمكن لغيرها أن تدخل بعدها هذا البيت،

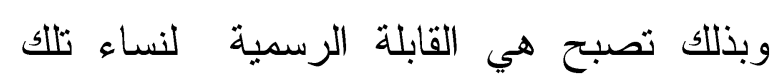
الأسرة، وقد ابتدعت هؤلاء القوابل حجة لاحتكار القبالة، وهو أن دم المولود ودم أمه وقع على يد القابلة الأولى، فلا يدخل غيرها عليها. ومن الواضح أن ذلك بدعة لا أصل لها في الشرع، وقد انتقدها ابن الحاج في كتابه "المدخل"، و أكد أنها لا صلة لها بالشرع من قريب أو بعيد. وقد

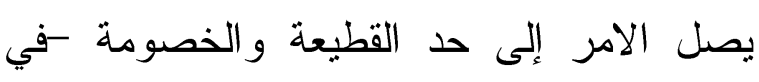
حالة الاستعانة بقابلة أخرى- بين القابلة وأهل البيت الذي عملت فيه أول مرة من جهة، وبينها وبين القابلة الجديدة من جهة أخرى، وهذه المنافسة دفعت بعض القابلات لابتداع أمور خارجة عن الثرع في سبيل الترويج

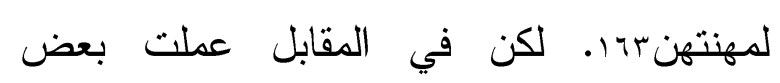
القو ابل دون أجر احتسابًا للأجر من الله مثل أم أحمد التي عاشت في العصر المملوكي عَ'. وخلال القرن الثامن الهجري I الرابع عشر الميلادي كانت فرنسا و المانيا ومدن أخرى

${ }^{162}$ Applebaum, The Concept of Work, p. 299. ז"ابن الحاج، المدخل،ج"، ص00.

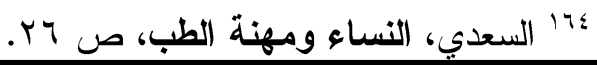

ويوجد مثل شائع في العصور الوسطى

يقول "كلما كانت الساحرة أفضل، كانت القابلة أفضل "؛ وللوقاية من السحر ،طلبت الكنبسة من القابلات أن يعتمدهن المطران ويقسمن على عدم استخدام السحر عند مساعدة النساء أثناء المخاض "17. وكانت القابلات يلجأن في حالة الو لادات العسرة إلى تقطيع الجنين لتخليصه من

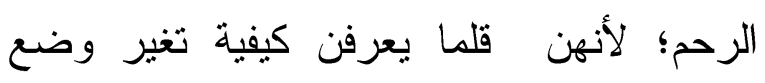
الجنين "ا". مما يدل على افتقار تدريبهن إلى لى لئ در اسة النشريح. وتبدأ القابلة في أوروبا واجباتها في هذه المهنة عن طريق القابلات الأخريات، وبعض الأحيان عن طريق آبائهن أو أزواجهن الذين كانوا يعملون في الطب، وكانت المرشحة لامتهان القبالة، تدرب نفسها على بد قابلة أكبر سنا وذات خبرة، فتحصل منها على المعلومات و التوجيهات اللازمة لاحتر اف هذه المهنة، وكان أهم شرط لتصبح قابلة أن تحصل على خطاب حسن سيرة وسلوك من القس، يعلن فيه أن

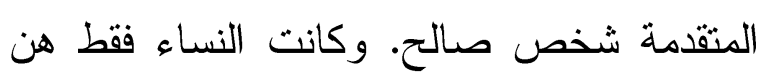
المسموح لهن بممارسة القبالة، ولا يساعدهن الأطباء خلال عملية الولادة، أما الرجال فيبعدون من غرفة المخاض، فالقابلة لا غنى عنها، لذلك كانت القابلة قادرة على فعل ما يحلو الها ووضع معاييرها الخاصة، لذلك ظهرث كتب تحدد و اجبات القابلة. و لأهمية مهنة القبالة، قام مجلس

${ }^{160}$. Derirde, witches, midwives, pp.4-12; http://ar.wikipedia.org/wiki .

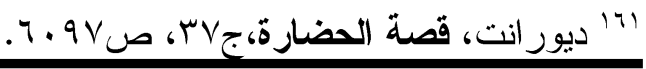


كانوا يملكون الخبرة المطلوبة، فكانت الممرضات و القابلات خير عون لهم للقيام بهذه المهمة"ال'. وحصلت القابلات في فرنسا على رخصة الممارسة بعد خضوعهن لاختبار من قبل الأطباء المحليين. وكان على القابلات الحصول أبضًا على ترخيص و اجازة لتعميد

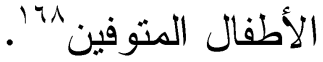

وأطلق اليهود على القابلة اسم المرأة

الحكيمة، ولم تكن الحكمة المتطلب الوحيد لليهودية لهذه المهنة، فالقابلة المناسبة في نظر اليهود خلال العصور الوسطى هي المرأة التي تخاف الرب، و المحترمة المتعلمة و الحكيمة و الذكية و النظيفة و البريئة، و القوية و الماهرة و الصبورة، والتي اعتادت العمل في الأمور

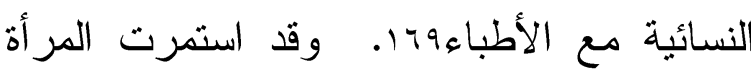
اليهودية في ممارسة مهنة التوليد على الرغم من أنها كانت في بعض الأحيان تزغم على دفع غرامة، بل كان يحكم عليها بالموت في أحيان

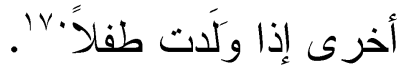

\section{طبيبات العيوز أو الكحالات :}

ظهرت في أواخر خلافة بني أمية طبيبة

تسمى زينب، و اشتهرت بين الناس باسم طبيبة بني أود، وكانت مختصة في أمراض العيون، وقد أشار ابن ابي أصيبعة في كتاب 》 طبقات

${ }^{167}$ Newman, Ibid ,p.266 •

168 Olsen, chronology of Women's History, p. 57 .

${ }^{169}$ Klein, Michele, A time to be born: customs and Folklore Of Jewish Birth, Jewish Publication Society, p.p. 123-124.

${ }^{170}$ Klein, A time to be born: customs and Folklore, p. 124.
في أوربا، تشترط اجراء اختبار للقابلات ومنحهن رخصة قبل السماح لهم بممارسة

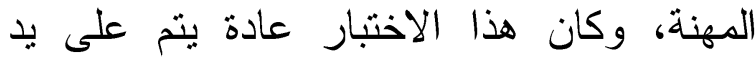
الأطباء أو رجال الدين، ولكن في مدينة واحدة على الأقل من مدن المانيا كانت مسؤولية اجراء مثل هذا الاختبار تتم على يد مجموعة من اكثر نساء المدينة احتر اما وتقدير ا، و إلى جانب تز اخيص القابلات، للمحافظة على قدر من الرقابة على عملهن لضمان جودته ، كانت بعض السلطات المدنية ، خاصة في المانيا تحتجز القابلات لتوليد أي امر أة حبلى في المدينة بغض النظر عن قدرتها على الدفع 170. وفي حين كانت القابلات يتدربن بشكل مستقل عن الأطباء، كان بعض الطبيبات بعملن كمساعدات للأطباء، فكن يعملن في المستشفيات كمدرضات، ويرعين المرضى، و العديد منهن بنتمين إلى النظام الديني سواء كن راهبات أو مساعدات ، حيث كن يؤدين واجبات التمريض كجزء من وظيفتهن الدينية"174. و وكانت الممرضات و والقابلات ضروريات لاستكمال مهمة الكشف على

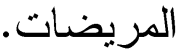

وسواء كان التدريب خاص أوفي المستشفيات، كانت الممرضات يعملن مع الأطباء في معاينة المريضات، لأن معايير الحشمة والأخلاق في ذلك الوقت، تمنع الأطباء من مباشرة الكشف على المريضات بأنفسهم حتى لو

${ }^{165}$ Newman, Daily Life in The Middle Ages,p.266; Olsen chronology of Women's History Nearly, p. 57 .

166 Newman, op. cit,p.266 . 
ولتعالج أمراض النساء وتساعد النساء الحبلى

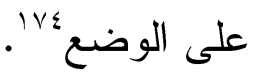

ومهما يكن نوع التخصصات الطبية التي

مارستها المرأة سواء في العالم الإسلامي أوفي أوربا، فإنها كانت عرضة للوقوع في بعض المشاكل والمتاعب مع المريضات، وأكثر الخلافات الموثقة بين الطبيبات المريضات كانت تقوم حول الأجر، فقد اثـارت إحدى المصادر إلى خلاف بين امرأة مسلمة وطبيبة بالأندلس حول حساب غير مدفوع '

الاختبارات الطبية والرخصلة المهنية:

من الأمور التي تميز بها العالم الاسلامي في المجال الطبي، تصفيته من الدخلاء الذين لا ير اعون أخلاقيات المهنة و آدابها، وشكل وجودهم خطراً يهدد أرواح الناس، لذلك كان فرض اجتياز امتحان على ممارسي مهنة الطب يشكل أحد الحلول الناجعة للمشاكل الناجمة عن عدم احتر ام المعايير العلمية و و الأخلاقية للمهنة.وكان الإلمام بالطب الإغريقي هو المعيار الوحيد للحصول على العضوية في هذه المهنة. فأي يهودي أو مسيحي أو مسلم، كان بطمح إلى ألى ممارسة الطب، وجب عليه أن يدرس النصوص بوس بوس الطبية اليونانية. كما كان الأطباء المتمرسون يقرؤون، وعادة ما يحفظون عن ظهر قلب، الكتب الستة عشر لجالينوس. وعندما انتشرت

174 Solomon, Michael, The Literature of Misogyny in Medieval Spain, the Arcipreste de Talavera, p. 149.

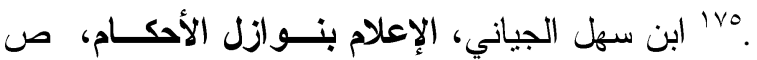

الأطباء « إلى طبيبتين مسلمنين ، درستا الطب و اشتغلتا به ، منهما الطبيبة 》 زينب 《 طبيبة بني أود التي برعت في علاج امراض

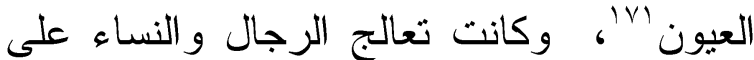
السواء. وذكرت النساء اليهوديات في القدس باسم الكحالات ، وهو مسمى خاص بطبيبات العيون، ويفهم من كلام كوهن أمنون أن هؤلاء

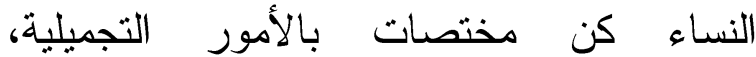
ومحترفات في وضع الكحل لتجميل العيون، وبهذه الطريقة أصبحن خبيرات في أمراض

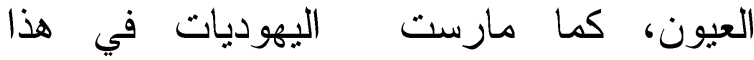
الاختصاص في ألمانياطY'. وفي فرنسا وايطاليا كانت اليهوديات أحسن أطباء العيون، ونالت بعضهن شهرة جيدة مثل : ربيكا و وفرنسيسكا - IVr

وزاولت النساء في بلنسية الطب بكافة

جو انبه ، فكان منهن القو ابل، و الاخصائيات في أمراض معينة كالعيون على سبيل المثال، بالإضافة إلى الطب و الجراحة العامة، و عالجن الرجال و النساء والرجال على السواء. ولعبت الطبيبات في كاتلونيا درورا اساسيا في العناية

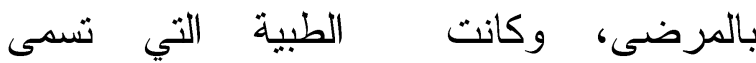
Catalan Exarmadora لمعالجة المرضى الذين يعانون من النقرس

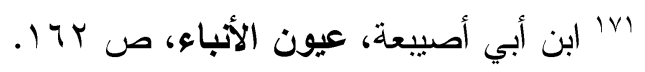

172 EmilyTaitz,Sondra Henry,Cheryl Tallan, The JPS guide to Jewish women: 600 B.C.E.- 900 C.E, Jewish publication society, America, 203, p. 88.

${ }^{173}$ Maintain, Peter and Pulley, Richard, Medicine Through the ages, Cheltenham, England, Stanly Thorens publisher, Second ed, 1997, p. 76 
وتعطينا هذه القصة -بغض النظر عن مصداقيتها- دلالة على اهتمام المسلمين بصفة عامة بالعلوم الطبية. كما تلقي الضوء على نوع التعليم الثامل الكامل الذي كان يتاح للمسلمين في ذلك الوقت. وقد استفاد الأوربيين من احتكاكهم بالمسلمين في الحد من هذا النوع من المعالجات و الطبيبات الدجالات عن طريق فرض اختبار للأطباء لتأكد من أهليتهم لممارسة هذه المهنة، للحفاظ على أرواح الناس من العابثين والعابثات، فقد أمر روجر الثاني ملك صقلية عام

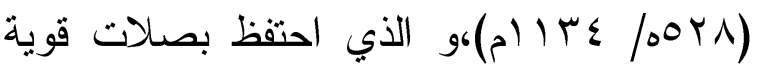
مع الأطباء المسلمين، وحفيده فريدريك الثاني بعقد امتحان لكل من يرغب في ممارسة الطب،وضع روجر قانوناً أملاه بنفسه، ينص لئر على أن يدرس الأطباء مواد في الطب لمدة

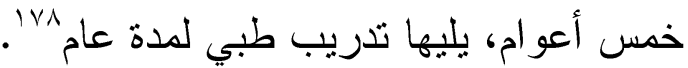
وفي شبه الجزيرة الأيبيرية منع الفونسو

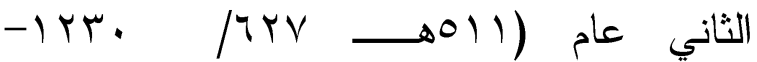
111) أن يتم امتحانه بواسطة طبيب، بالإضافة إلى إلى

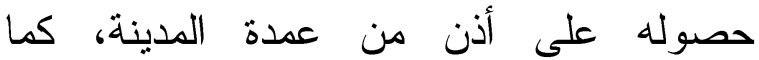
أصدرت محكمة بالنسية قرارا عام(بس7هــ| qبr (م) يلزم كل طبيب الحصول على شهادة

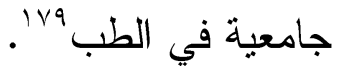

وصدرت مراسيم أخرى تحظر عمل النساء في الطب، فقد أصدر مجلس بالنسية قانوناً يمنع المرأة من مزاولة الطب ، كما منع

${ }^{178}$ Fuster, Women Healer And Physicians, p. 58

179. Fuster., Women Healer And Physicians, p.79
الكثب الطبية التفسيرية والرسائل المتخصصة، تحول طلبة الطب إلى كتيبات مختصرة و إلى

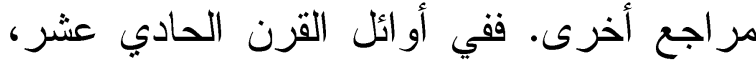
ضُمَ إلى قائمة الكتب الأساسية كتاب الرازي :" الحاوي في الطب"، كتاب ابن سينا: "القانون في الطب" وكتاب الدينوري : "كتاب النبات" "Y^اب . على كل حال، كان هذا الإجراء شائعًا في العالم الاسلامي، لمن يمارس الطب بكافة فروعه، رجالاً ونساءً، وقد تتاولت المصادر الأدبية في ذلك الوقت هذا الموضوع بإسهاب. ويحكى عن جارية دوهوبة عرضت للبيع على هارون الرشيد بثن باهظ، فوافق الخليفة على دفع هذا الثمن بشرط أن تجيب الجارية على أي سؤال يوجهه لها أعلم الحاضرين في تلك الفروع من المعرفة التي كانت تدعي النبوغ فيها. وبدأ كبار علماء الدين و القانون وتقسير القرآن و الطب و الفلك و الفلسفة و البلاغة و الشطرنج يمتحنونها الواحد تلو الآخر، وفي كل فرع من هذه الفروع لم تكتف الجارية بإجاباتها البارعة على كل ما وجه إليها من أسئلة، ولكنها كانت تطرح على أستاذ كل فرع في نهاية الامتحان عددا من الأسئلة لم يحر لها جوابا له 'VV وكان الامتحان الخاص بالطب يشتمل على موجز علم التشريح، و علم وظائف الأعضاء، وتشخيص الأمراض لـ من و اقع الأعر اض، و علم الأمراض، و الصحة و علم التغذية إلى غير ذلك من فروع الطب.

$176 \mid \backslash Y-1 \backslash$ Miller, doctors without borders, pp. ألف ليلة وليلة، ، جrv

Burton, The Arabian Nights, V, v, pp. 189-245; Prioreschi, Pinio, A history of Medicine 


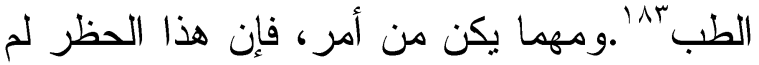
يدم طويلا، فإن الملك رفع هذا الحظر بعد أربع بـن سنوات من صدوره ، بسبب نقص الرعاية Valladolid الصحية. وقد جعل مرسوم بلد الوليد عام (1/11/11/2) الظروف المعيشية أكثر صعوبة للجالية اليهودي ، ويشمل التشريع منع الأطباء اليهود و المسلمين رجالاً ونساءً من رئه ممارسة مهنة الطب و الجراحة، ولكنه أصبح تدريجيًا غير فعال؛ الأطباء اليهود والنصارى كان يتلقون نفس التدريب الطبي، ويتقاسمون نفس النصوص الطبية؛ لذلك لم يلحظ المرضى فرقاً كبيرًا في العلاج الموصى به من أطباء هاتين الملتين ولم يمنع الحظر الناس من زيارة الأطباء الذين يأتمنونهم على حياتهر واستدعائهر عند الحاجة مهما كانت ديانتهم ء^ا، كما أصدر

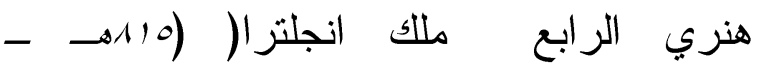

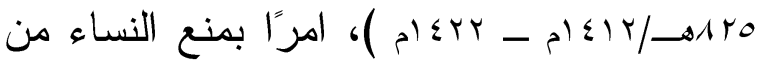
ممارسة الطب، وجعل السجن عقوبة لكل من

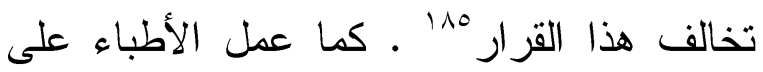
احتكار صناعة الطب دون النساء، ففي

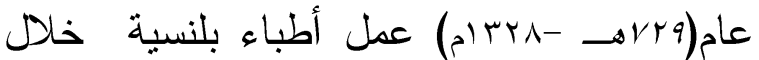
مجلس البلدية على تعزيز احتكارهم لرخصة مزاولة مهنة الطب عن طريق إصدار أمر بمنع النساء sن الممارسة الطبية، ومن تخالف هذا الأمر سوف تجلد عبر المدينة، ويستثى من ذلك

${ }^{183}$ Freudenthal, Science in medieval Jewish, p. 336

${ }^{184}$. Freudenthal, Science in medieval Jewish, p. 340

185. Applebaum, Concept of Work, p. 299.
مجلس كستاليا عام/ V/ هـ/r/ ها م) الأطباء اليهود من معالجة النصارى، وجاء في قرار المجلس:" يجب أن يمنع اليهود من تطبيب النصارى مهما كانت كفاءتهم الطبية وخبرتهم"،

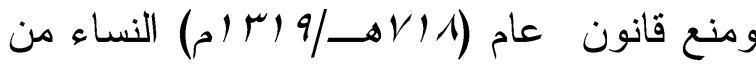
الممارسة الطبية، ولكن نظرا لشعبيتهن، فقد نجون في أحيان كثيرة من العقوبة، على الأقل في البداية'^|'وكان على البهود- من الجنسينالذين يرغبون في تطبيب النصارى الحصول على رخصة بمزاولة مهنة الطب، أما الذين يحصرون ممارستهم لمهنة الطب على أبناء دينهم فلا يلزمهم الحصول عليها، و إذا زاولت اليهودية الطب دون رخصة، ثم قدمت التماسا للملك، فإنه يحكم بأن ليس عليها الحصول على رخصة؛ لأن تقديمها الرعاية الصحية محصور في أبناء طائفتها فقط' 'م'ا. وفي عام ( أفينيون MrAvignon العلاج على أيدي الأطباء و الجراحين اليهود، أو طلب الدواء منهم، وفي نفس السنة صدر أمر بسحب كل الصلاحيات السابقة للأطباء اليهود، ومنعهر من ممارسة

${ }^{180}$ Smith, Virginia, Clean: A History of Personal Hygiene and Purity, Oxford, 1989, p. 31.

181 Freudenthal, Gad, Science in medieval Jewish Culture, Cambridge University Press, p. 336 بشا هي بلدية في إقليم فوكلوز في جنوب شرق فرنســا. تشتهر المدينة بقصر البابوات حيث عاش العديد مـن فين البابوات المزيفين منذ أو ائل القرن الرابع عشر إلـى لـى لصع بدايات القرن الخامس عشر الميلادي. انظر عنها:

"Catholic Encyclopedia, Avignon New York: Robert Appleton Company. 1913 
في بلد الوليد مرسوماً يمنع بمقتضاه المسلمين

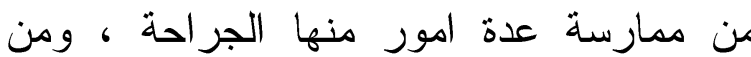

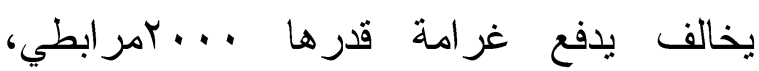

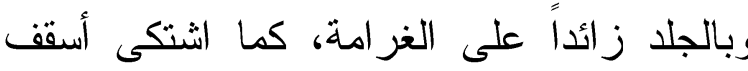

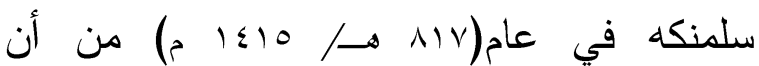
المعالجين المسلمين و اليهود يستغلون بخبث المرضى النصارى، تاركين أجسادهم أكثر ضعفاً مما كانت عليه 199.

ومهما يكن من أمر، فإن هذه القيود لم تطبق فعلياً الا في القرن الخامس عشر؛ فقي لفرن

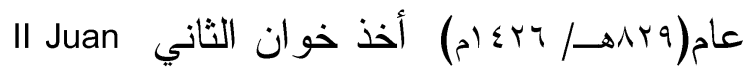
بنصيحة الطبيب الفونسو Alfonso Chirino، و أنشأ محكمة لاختبار الأطباء، وفي عام (1Mr هـ -

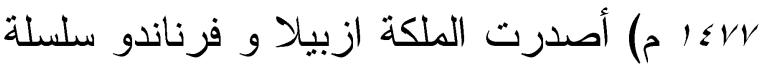
من القوانين تطورت إلى هيئة مركزية، تم

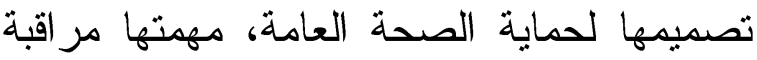
المهن الصحية و التّريس و التدريب احتيار المعالجين ومعاقبة الأطباء غير المؤهلين ول19. و لاشك أن هذه القو انين كانت تستهدف المعالجين و الاطباء رجالاً ونساءً. ويتساءل الباحث مانت لهايكل

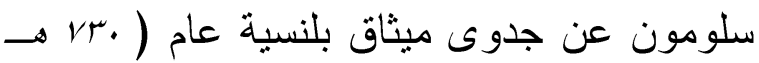
/ وبrام) ، الذي حُظر بموجبه على النساء ممارسة الطب، إذا كان نشاط المعالجات و الطبيبات لم يتوقف، ويمضي في تساؤله قائلاً: لماذا نستمر في العثور على نساء مارسن

${ }^{189}$ M.Michal ,Luis. García Ballester ,Medical Licensing and Learning in Fourteenth Century Valencia, phladiphia, 1989, pp.30-32

${ }^{190}$ Solomon, Michael, The Literature of Misogyny in Medieval Spain, the Arcipreste de Talavera, p. 52 .
تقديمها الرعاية للأطفال و النساء بدون

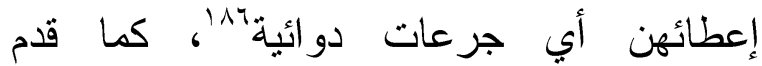

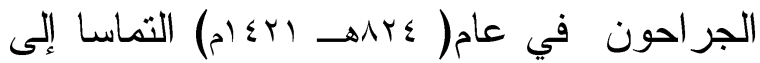
البرلمان لتقييد ممارسة الطبية للنساء اللاتي لم يكن يملكن الموهبة الفطرية و لا حتى المعرفة المهنية، مما قد بتسبب في قتل مرضاهن، لأنهن

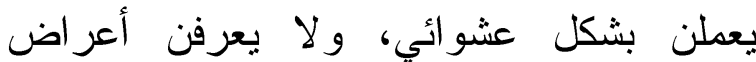
ومسبيات الأمراض، التي يزعمن أنهن مؤهلات

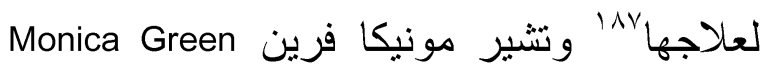
أن ضبط منح رخصة ممارسة الطب في العصور الوسطى المتأخرة كان الهدف منه الحد فئه من أنشطة النساء في المجال الطبي، بينما يرى البعض الآخر أن هذا التنظيم كان بيتهدف الطبيبات المسلمات، لأنهن يشكلن النسبة الأكبر من النساء اللاتي يطلبن الحصول على رخصة

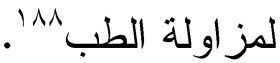

وكانت الطبيبات في أوروبا هدفًا للتمييز

العرقي والديني، وبشكل خاص الطبيبات المسلمات، فلم يكن الحكام الغربيون على تسامح

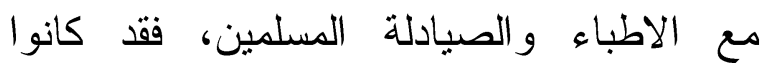
يضايقونهم ويتعفون عليهم، ويصدرون المر اسيم، ويسنون القو انين التي تحد من نشاطهخ رجالاً ونساءً. فمنذ القرن الرابع عشر الميلادي

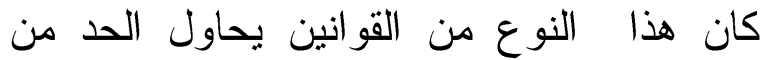
الممارسة الطبية بناء على العرق و الجنس؛ فقي

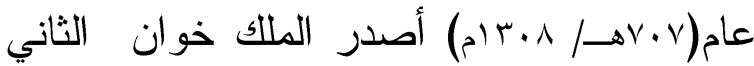

\footnotetext{
${ }^{186}$ Nierenberg, Communities Of Violence :,pp. 120121.

${ }^{187}$ Olsen, chronology of Women's History, p. 57 . ${ }^{188}$ Nierenberg, Communities Of Violence, p. 121
} 

الأنشطة الطبية في بلنسية دون مقاضاة ، ولماذا السراسنة ا919 سواءً أكانت مسلمة أو يهودية من لم تقابل أنشطة النساء في برشلونة على وجه العمل كطبية "Metgessa" ، حتى لا ل تحضر

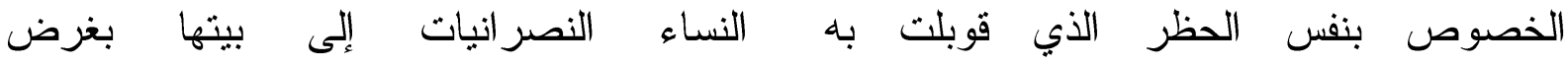
أنشطتهن في كتالونية. لكن يبدو أن السبب وراء المعالجة 19

ومهما يكن من أمر، فإنه بعد أربع سنوات من ميثاق بلنسية تنامى إلى مسامع الملك بيدرو الر ابعPeter IV إثـاعة عن امرأة مجهولة الاسم كانت تمارس الجراحة في برشلونة، وتؤذي مرضاها؛ لعدم كفاءتها وتمكنها من المهنة، وعوضاً عن كف يدها عن الممارسة نهائيا، أمر أن يعقد لها اختبار من جراحين ذوي خبرة، يمتلكون القدرة على تقييم مهارتهاء9 19. كما منحت هوي منحت بعض الطبيبات اليهوديات في اسبانيا الرخصة الطبية؛ ففي وثيقة مؤرخة في 10

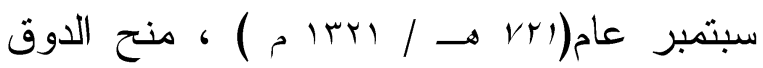
الأذن لطبية يهودية بالعمل كجراحة، مفيدا أنها

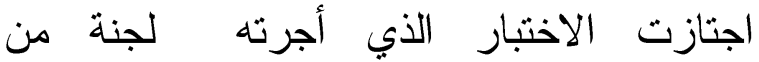
الجر احين و الأطباء الملكيين، حيث وجدت اللجنة أنها تملك المعرفة الكافية لممارسة الطب، وذكر في نفس هذه الوثيقة أن المرأة أفضل من الرجل

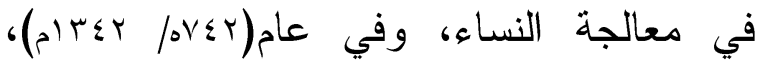

191 مصطلح كان يطلق في العصــور الوســـى علـى الثرقيين خاصة على العرب و المسلمين. انظر عنــه: النصرات، محمد، السر اسنة (Saracens) وعلاقتهم بالامبر اطوريتين الرومانية والبيزنطية (القرنين الثالث و الر ابع الميلاديـين)، دراســات، العلـــوم الإنســانية

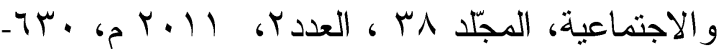
$.7 \leqslant \wedge$

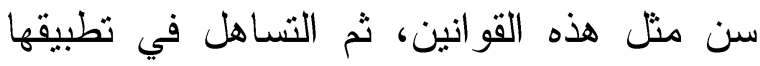
يحكمه العامل المادي، لأن الغرض منها الابنز از لهاز المادي بالدرجة الاولى، فعند التدقيق في الوثائق التقان الخاصة بالرخص الطبية الممنوحة لطبيبات المسلمات في بلنسية خلال القرن الثامن الهجريا

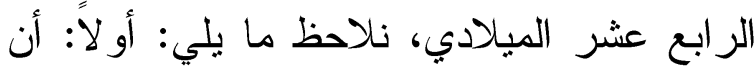
هذه الرُخص لم تمنح عن طريق المتحنين المحلين أو المجلس البلدي لمدينة بلنسية، وإنما لإنا منحها الملك بنفسه في كل الحالات، لأنه وجد

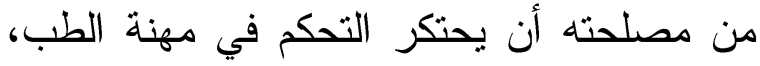
و الذي خوله ميثاق بلنسية للسلطة البلدية. ئانياً: أن معظم اللاتي حصلن على رخصة المزاولة هن الطبيبات المسلمات. ويفهم من ذلك أن تحريم

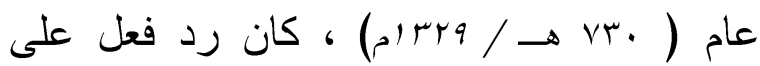
ظاهرة عدها النصارى تهديد ثقافياً ودينيًا أكثر ردار من كونها تهديدًا مهنيًا؛ خاصة وأن الطبيبات المسلمات في الأندلس تمنعن بمكانة حقيقة في المجتمع ، و واستطعن التغلغل داخل العائلات النصر انية، ومارسن الطب بين السكان النصارى

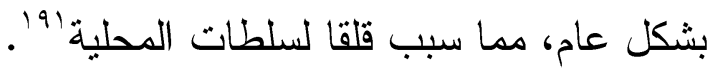
على كل حال، فإن السبب الحقيقي وراء

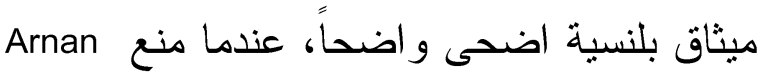
Camorra

193 M.Michal, Op. Cit, p.31.

194 M.Michal, Medical Licensing, p.31. 191 M.Michal , Medical Licensing pp. 30-32. 
النساء عن المجال الطبي، ومنها ما كان بدافع التمييز الديني و العرقي.

على كل حال، كانت الطبيبات بصفة عامة بغض النظر عن الديانة هدفاً للاضطهاد

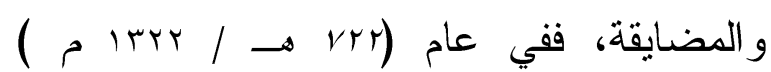
Jacoba حوكمت الطبيبة الإلمانية جاكوبا فليكر في باريس لمزاولتها الطب دون Felicre ترخيص، وقد شهد ستة شهود بكفاءتها، وأنها أكثر تأهيلًا من الأطباء الذين يحملون الثهادة الجامعية، ودافعث جاكوبا عن نفسها، بأن لديها المعرفة العلمية، وأن الطبيبات ضروريات من أجل المحافظة على حشمة المريضات وَ'1. كما حوكمت الجراحة بريتا بيتون في عام

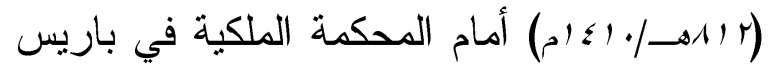
بتهمة الممارسة بدون رخصة، ولم تتكر بريتا التههة، بل على العكس من ذلك قالت بفخر أنها تدربث على يد أحد أقربائها، وعدد من الأطباء

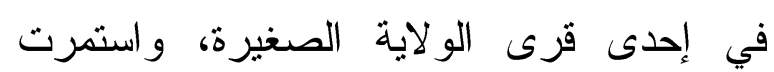
تمارس الطب خلال السنوات الثمان الماضية بنجاح كبيز، وقد طالبت مريضاتها أنفسهن بإطلاق سراحها عندما حبست لأول مرة مدةً تجاوزت السنة، وكان هدف مجموعة الجراحين الذين رفعوا القضية علبها إثبات عدم أهليتها وكفاءتها لممارسة مهنة الطب، واستندوا في الي جدالهم على أميتها. وطبقا لرواية بريتا نفسها، عقد مجموعة

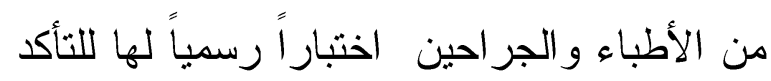

كانت استروقا البرشلونية تمارس الجراحة على المرضى اليهود فقط، ولم يكن عليها المرور باختبار طبي قبل الحصول على الرخصة. كما منح بيدرو ملك أرغون طبيبتين يهوديتين من ليردا في مملكة أرغون الرخصة 190.

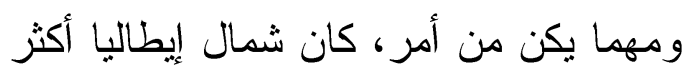
مناطق اروبا نسامحا في منح الطبيبات رخصة الممارسة، ومن خلال معالجة البيانات التي تخص التزاخيص الممنوحة في نابولي، نستتج أن هناك عاملين سهلا هذا الأمر، الأول:ان الترخيص بيتطلب الخبرة، الثاني: استعداد السلطات اصدار تراخيص جزئية تحصر المعالجات في حقل طبي معين و اضح الحدود، وأكثر النساء المرخصات في جنوب ايطاليا قيدت ممارستهن لطب في جانب واحد مثل" علاج الجروح"، "معالجة النساء"، ولكن لـ يكن ذلك قانوناً دائماً، فلم نجد مثل هذا التقييد في رخصة، ولا في رخصة وهي امر أة من جنوب ايطاليا، وكذلك لم نجد هذا القيد ايضًا في رخصتين تعودان إلى الربع الأخير من القرن الثامن الهجري/ الرابع عشر الميلادي 194. ويتضح مما سبق تتوع أسباب فرض الرخصة المهنية على المعالجات و الطبيبات، ما بين أسباب وقائية ومهنية لضمان سلامة الناس وحفاظًا على ارواحهم، ومنها ما فرض بدافع المنافسة وأسلوب من أساليب الاقصاء؛ لإبعاد

195 Applebaum, Concept of work, pp. 298-299

${ }^{196}$ P. 110. Shatzmiller, Medicine, and Medieval Society, P. 108 
من معرفتها الطبية، وكانوا يسخرون منها حدة المنافسة والتضييق سوى التقهقر و ويرمقونها بنظرات ملؤها الاحتقار، وأخذوا الانزواء، لذلك تقهقر عدد العاملات في المجال الكتب الطبية التي أحضرتها معها ، وقلبوا الطبي من النساء حتى تلاشى تماماً خلال القرن السادس عشر الميلادي. وفي حين كانت الرخصة الطبية وسيلة لتنظيم العمل الطبي في العالم الاسلامي، وتطهيره من الدخلاء عليه، وضبط الممارسة الطبية، اتخذها أطباء أوربا هُهاء وسيلة لإقصاء العاملات في المجال الطبي وتقليص أعدادهن، وكان المحرك الرئيس في هذه المنافسة هو الرغبة في الاحتكار الاقتصادي. ومما يلفت الانتباه أن معظم العاملات في الحقل الطبي في أوربا هن من بنات الطائفة اليهودية، ويعود السبب في ذلك إلى احترام الطائفة للطبيبات، كما أن معظمهن ينتمين لأسر طبيبة، مما اتاح لهن فرصة الصفحات أمامها و أمطروها بأسئلة عن الطريقة التي تحضر بها أدويتها، وسألوها مباشرة إن كانت تستطيع الإجابة فأجابت بالإيجاب، وفي

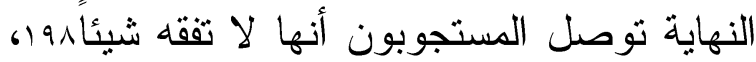
لأنها لم تسنطع أن تقرأ عناصر نظرية طبية موجودة في الكتب 199. و هكذا يتضح مما سبق دو افع عقد الاختبار ات الطبية للطبيبات و الممارسات للمهن الطبية وضو ابط منح الرخص المهنية لهن في كل العالم الإسلامي و الغرب الأوربي خلا العصور الوسطى. التدريب والممارسة أكثر من الأوربيات، وقد استقدن من مهارتهن الطبية في الحصول على الحظوة لدى أمراء وملوك أوربا، ومن الملاحظ ان ايطاليا كانت أكثر بلدان أوربا في ذلك الوقت تسامحاً مع العاملات في المجال الطبي، فأول جامعة اتاحت للمر أة دراسة الطب وغيره من العلوم الطبية هي جامعة ساليرنو الايطالية، ولعلها اكتسبت هذا التسامح من خلال احتكاكها العلمي و الثقافي بالعلماء و الأطباء المسلمين. كما أتضح من خلال البحث ت تنوع وسائل التعليم و التدريب التي تلقت المرأة بواسطتها تعليمها الطبي سواء في العالم الاسلامي أو في أوربا، كما تتبع البحث تطور مسيرة المرأة في المجال الطبي خلال العصور الوسطى، ففي حين 
واستعنت بهم العو ائل المسلمة و النصر انية على ألى السواء.

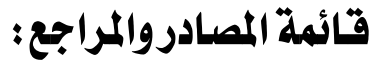

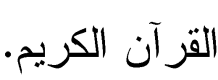

الكتاب المقدس (أي العهد القديم والجديد)، دار الكتاب المقس في الثرق الأوسط، القاهرة،

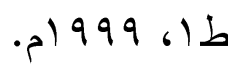

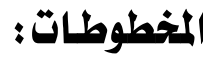

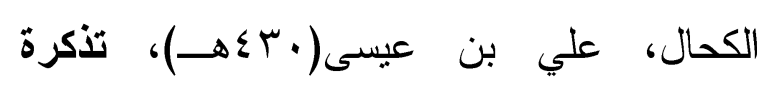

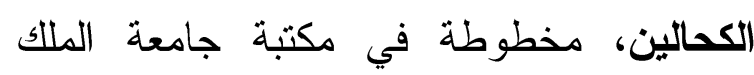

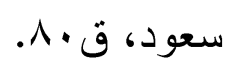

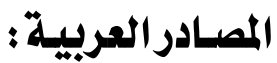

1. ابن الأثثر؛ عز الدين أبو الحسن علي الدائ

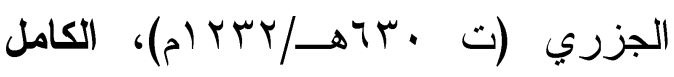
في التاريخ، تحقيق: عبد السلام تدمري،

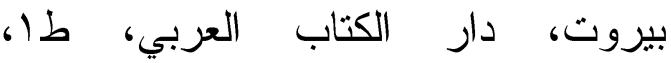

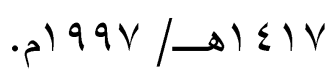

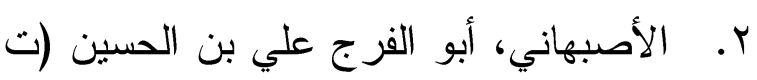

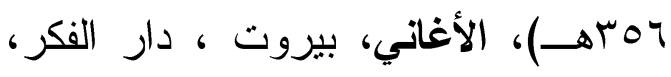

د.

r. ابن أبي أصيبعة، موفق الدين أبو العباس

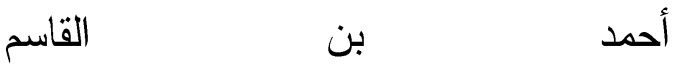

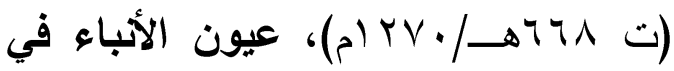

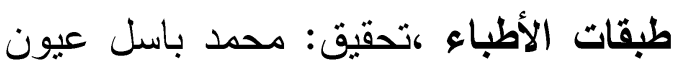

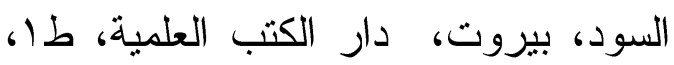

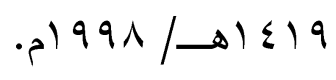

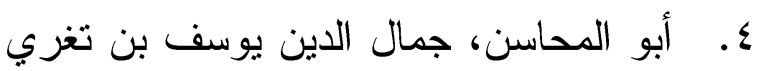

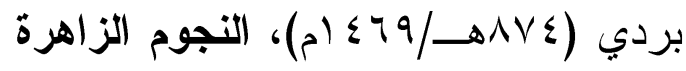

اتسم هذه المسيرة بالتقدم والارتقاء في العالم الإسلامي، لوحظ تزاجعها و انحطاطها تدريجيا

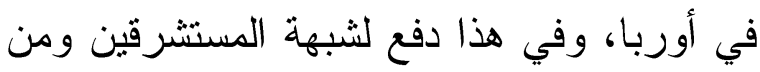
لف لفهم حول انحطاط مكانة المرأة في العالم

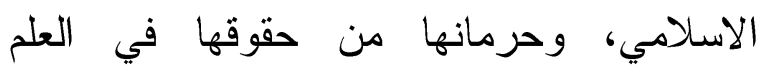
و المشاركة في بناء المجتمع، وأن هذه التهمة أنما

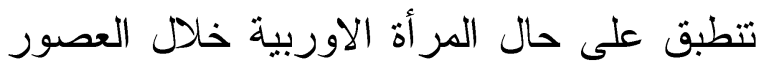
الوسطى.

ويعد طب العيون وأمراض النساء

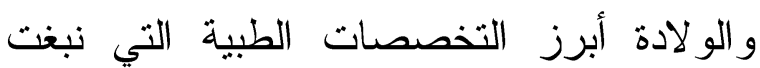
فيها المرأة خلال العصور الوسطى. وعرفت الطبيبات المسلمات بالخبرة و المهارة في علاج

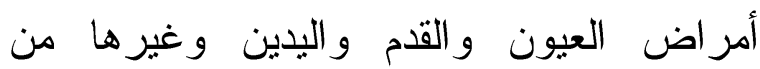

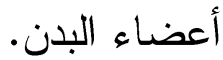
كما ظهرت في الدولة الأموية في الأندلس

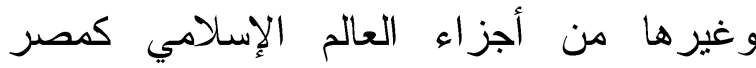
و الثام و المغرب، طبيبات شهيرات ينتمين إلى الى أسر علمية، فقد نبغت في أسرة الطبيب الثهير

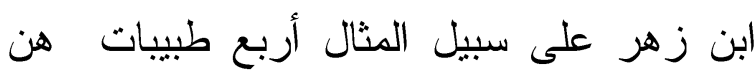

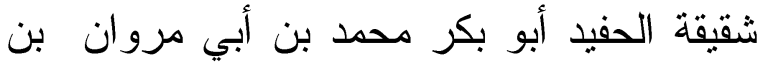

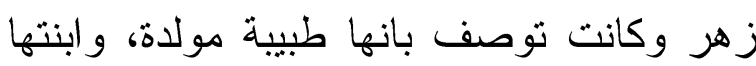
كانتا عالمتنين بالطب و المداو اة ولهما خبرة كبيرة بعلاج أمر اض النساء، وكذللك ابنته التي يدعوها البعض بالحفيدة بنت الحفيد، وابنتها، وجميعهن

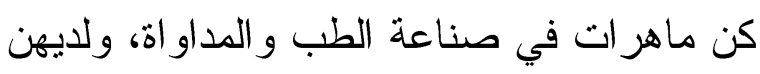

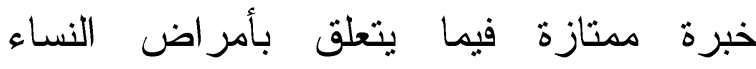

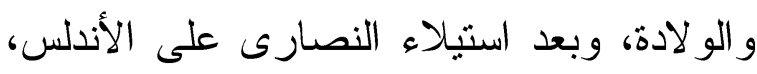

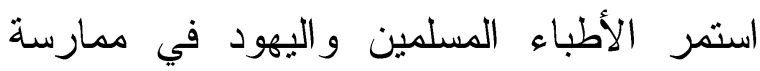
الطب، وحصلو ال على التزاخيص الطبية، 


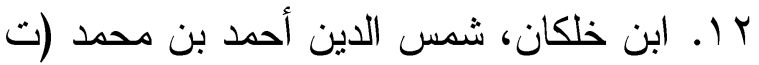

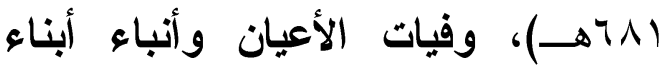
الزمان، تح: إحسان عباس، بيروت ، دار

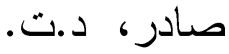

rا. أبو داوود، محمد بن (ت 9 •rهـ)، سنن أبو داود ، سليمان بن الأشعث السجستاني

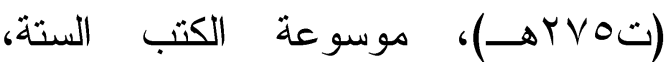

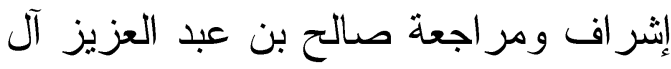

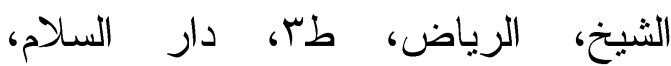

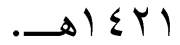

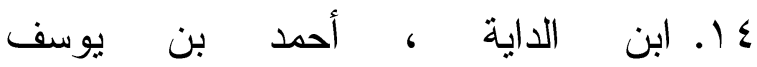
الكاتب (ت •ـ זهـ)، كتاب المكافاة وحسن العقبى، حققه وشرحه محمود شاكر، بيزوت، دار الكتب العلمية، د.ت.

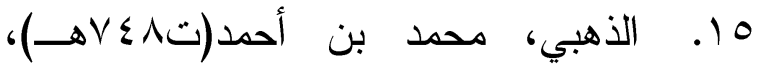

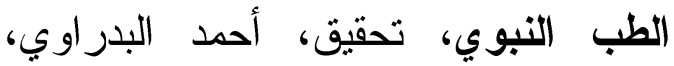

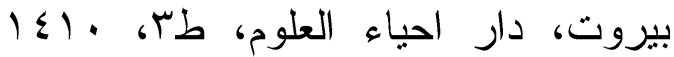

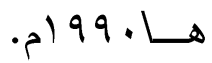
17. الرازي، أبو بكر محمد بن

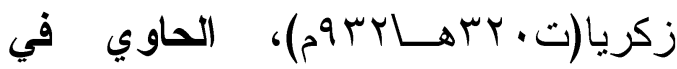

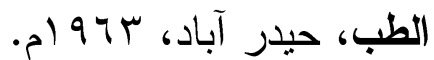

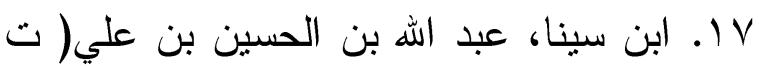
Y\&V

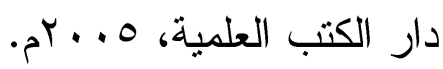
1ا. الطبري، محمد بن جرير (ت · •آهـ)، تاريخ الرسل والملوك، بيروت، دار الكتب العلمية ، طا ، كY (الهـ. 19. الزهراوي، أبو القاسم بن عباس العاس

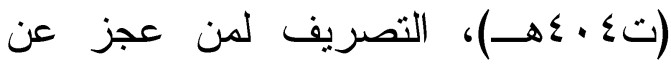

في ملوك مصر والقاهرة، تحقيق: محمد حسين شمس الدين ، دار الكتب العلمية،

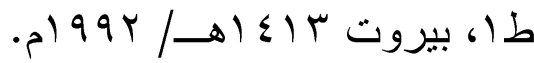
ه. ابن الحاج، أبو عبد اله بن محمد العبدري الفاسي ( الثرع الثريف ، بيروت، دار الكتب، מ ל T.

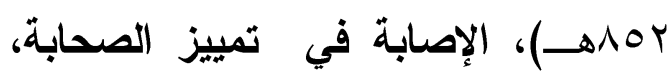

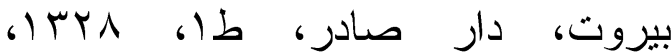

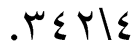

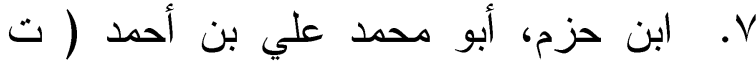

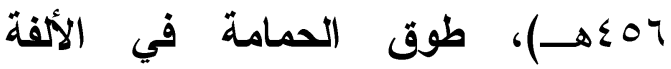
والو لاف، مصر، المكتبة التجارية الكبرى، .01909

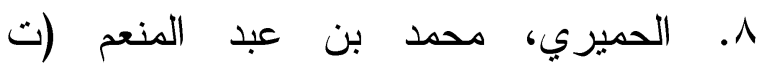

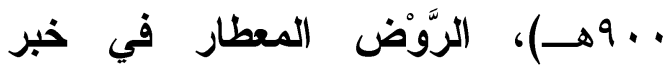
الأقطار، تحقيق، إحسان عباس، بيروت -

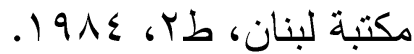

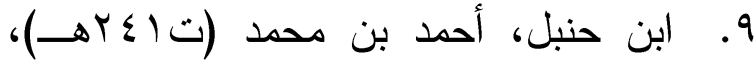
المسند، بيروت، دار إحياء التراث العربي،

$$
\text { . }
$$

• إ. ابن الخطيب، أبو عبدالَّهُ محمد بن عبداللَّه

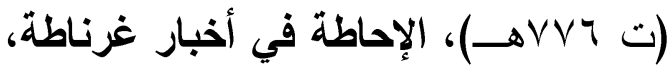

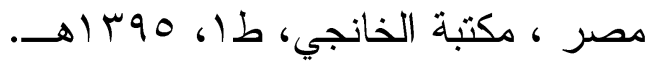
الـ ابن خلدون، عبد الرحمن بن محمد (ت

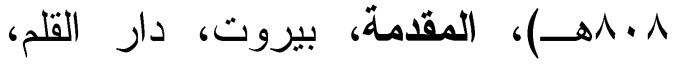
ط 
צr. ابن منظور؛ جمال الدين محمد بن مكرم

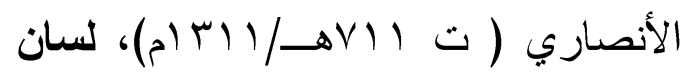

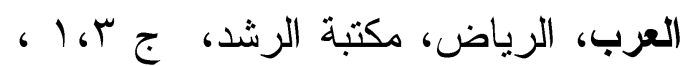

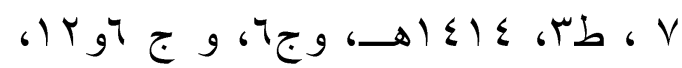
.(-) $\leqslant 1 V$ VV السلوك في معرفة الملوك، تحقيق، محمد بيضون، بيروت، دار الكتب العلمية، طا،

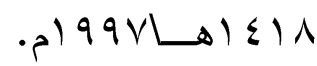
אץ. مؤلف مجهول، ألف ليلة وليلة، بيروت، مكتبة الحياة، (د.ت. ط).

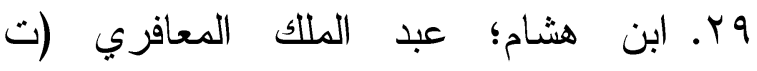

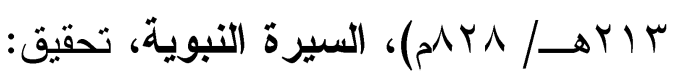
مصطفى السقا وآخرون، الرياض، مكتبة

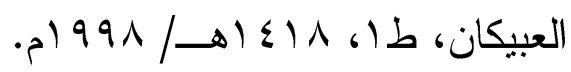
• r. الو اقدي، محمد بن عمر بن و اقد السهمي الأسلمي المدني الو اقدي (ت V.r. Vهـ)، فتوح الشام، بيروت، دار الكتب العلمية،

$$
\text { ط }
$$

اس. ياقوت الحموي؛ شهاب الدين بن أبي عبد

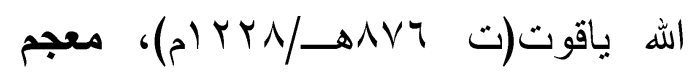
البلدان، تحقيق: فريد عبد العزيز الجندي، بيروت، دار الكتب العلمية، د. ط ، د.

المراجع العربية:

-ابن باز، عبدالعزيز بن عبد الله، مجموع

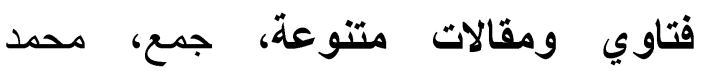

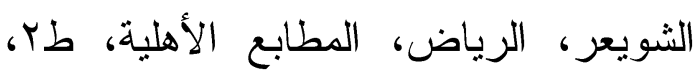

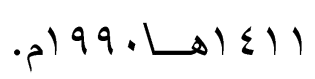

التأليف، تحقيق، عبدالهه عبدالرازق مسعود السعيد، الأردن، وزارة الثقافة، د.ت.

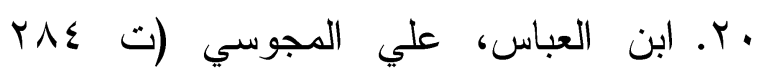
هـ)، ، كامل الصناعة الطبية، ، د.ت. ط. ا ا.. 21-ابن عذاري، أبو العباس أحمد بن محمد ( ت في القرن الثامن)، البيان المغرب في أخبار الأدلس والمغرب، تحقيق، ليفي بروفنشال، باريس، بولس

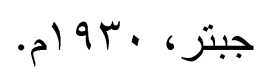
r r. ابن عبد البر، يوسف بن عبد الله (ت

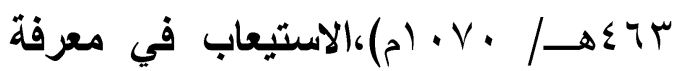
الأصحاب، تحقيق: علي محمد البجاوي،

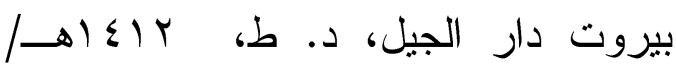
. $) 99 r$ سr. ابن قيم الجوزية؛ شمس الدين أبو عبد الله

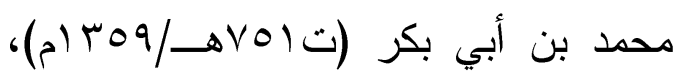
أحكام أهل الأمة، دراسة وتحقيق: سبد

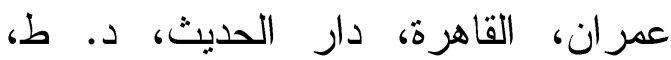
$\cdot r r+r / \Delta \leq r \leq$

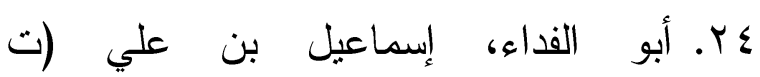
r. المختصر في أخبار البشر، تح: محمود ديوب، بيروت - دار الكتب العلمية، طا، لكون . I हाV هץ. ابن كثير أبو الفداء إسماعيل بن كثير

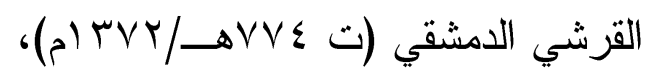
البداية والنهاية، بيروت د. ط، و الم. 
الطبيبات والثشتفلات بـالمهز الطبية خلال الفترة من القرن الأول حتى القرن التاسع الهجري : ... ـ ـ هيلة بنت عبد الرحمن بن فراج السهلي

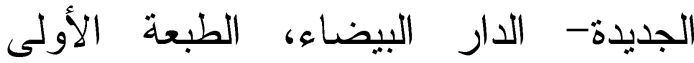

$$
\text { . } 9991-01 \leqslant 14
$$

-النصرات، محمد، السراسنة (Saracens) وعلاقته بالامبر اطوريتين الرومانية

و البيزنطية (القرنين الثالث والرابع

الميلاديين)، دراسات، العلوم الإنسانية

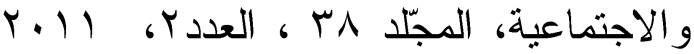

$$
\text { م، • }
$$

-ياسين، عبد اللطيف، فضل أطبّاء العرب على أوربّا في القرون الوسطى، مجلة التراث العربي-مجلة فصلية تصدر عن اتحاد الكتاب العرب-دمشق العدد OV - السنة 10 - تشرين الأول "أكتوبر" \99 ام - جمادى

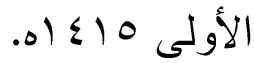

\section{المصادر الاجنبية ؛}

- Goitien, S.D ،Mediterranean Society, the Jewish Communities of Arab World or Portroyed in documents of the Cairo Genizah, 4 vols. Univ. of California, Press $1967-1978$.

-Mediterranean Society, the Jewish Communities of Arab World or Portroyed in documents of the Cairo Genizah, an abridgment in one volume, Univ of California Press, 1999.

- Dangier, Dan, Abject Pilgrimage and Healing In Jaume Rog,s Spill, Acta, His, Sci, Illus, 2003.

\section{المراجع واللدوريات الاجنبية :}

- Brooke E, Women Healers: Portraits of Herbalists, Physicians, and Midwives, Rochester, Healing Arts Press, 1995.

- Dols, Michael, Medieval Islamic Medicine, California, University Of California Press, 1984.

- Ashkenazi, Shlomo. "Famous Jewish women doctors, (1969-1970).
-أبو بكر، أميمه و السعدي، هدى، النساء، مهنة الطب في المجتمعات الإسلامية،

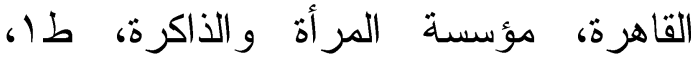

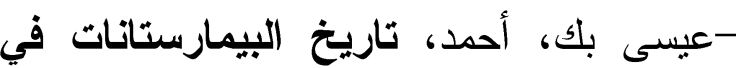

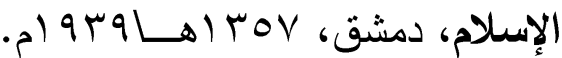

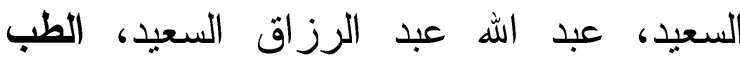

ورائداته المسلمات، الأردن، مكتبة المنار،

$$
\text { 6 } 91011 \leq .0 \text { b }
$$

-نوفل، عبدالرزاق، المسلمون والعلم العديث،

القاهرة، دار

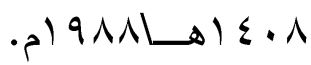

كرنسمان، ستيف، الحضارة البيزنطية، ترجمة عبدالعزيز توفيق جاويد، الهيئة المصرية

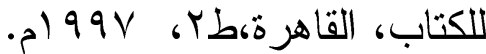

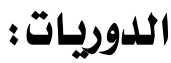

- بالكامل، البضاوية، نساء طبيبات في المغرب والألدلس، مركز دراسات الاندلس وحوار الحضار ات، الرباط، كلية الأدب و والعلوم

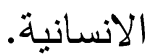

-السامر ائي، كمال، مقال الجراحة النسوية في العصور الإسلامية، في موقع أثر العلماء المسلمين على الجر احة و التشريح. -المنوني، محمد، تاريخ الوراقة المغربية

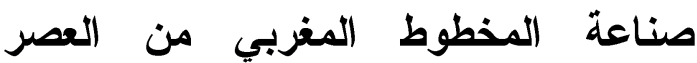
الوسيط إلى الفترة المعاصرة، منشورات كلية الآداب و العلوم الإنسانية بالرباط، سلسلة بحوث ودراسات رقم: r، مطبعة النجاح 
- Olsen, Kirstin, chronology of Women's History: Profiles Nearly 5000 Women World Wide, Library of Congress, 1994.

- Prioeschi, Pinio, Byzantine and Islamic Medicine, Horatius press, Omaha, first ed, 2001.

- Spink and Lewis, Albucasis and Surgical Instruments, California University Press.

- Green, Monica H. "Documenting medieval women's medical practice." In Practical Medicine from Salerno to the Black Death. edited by Luis GarcíaBallester, Roger French, Jon Arrizabalaga and Andrew Cunningham, 322-352. Cambridge: 1994.

- Hyamson, A.M; A history of the Jews in England, London, 1928.

- EmilyTaitz,Sondra Henry,Cheryl Tallan, The JPS guide to Jewish women: 600 B.C.E.-1900 C.E., Jewish publication society, America, 2003.

- Furst, R. Lilian, Women Healer And Physicians, UNS, The University Press Of California, 1997.

- Iftikar, Rukhsana, Labor class of women in Mughal India , South Asian Studies, A Research Journal of South Asian Studies, Vol. 27, N.1, JanuaryJune, 2012, pp. 233-246.

- Rajapal, Women Education in Early Medieval North Indians, International Referred Research Journal, June, 2012
- Burton, Richard, The Arabian Nights: Thousand Nights and A Night, London, The Burtun Club, 1885.

- Derirde, English, witches, midwives, and nuses: A history of Women Healers, Feminist Press, second Edition, Ny.

- Maintain, Peter and Pulley, Richard, Medicine Through the ages, Cheltenham, England, Stanly Thorens publisher, Second ed, 1997.

- Nikolas, Karl. Borchardt, The hisptallers, the Mediterranean, and Europe: Festschrift for Anthony, England, Ashgate Publishing, 2007.

- Newman, Paul.B, Daily Life in The Middle Ages, Library of Congress, Mcfarland company, Incm, Company, 2001.

- Eliott, Lynne, Medieval Medicine and plague, New York, USA, Carbtree Publish company, 2006.

- Johnson, P. (2000). The Renaissance : a short history. Modern Library chronicles (Modern Library ed.). New York: Modern Library.

- Kern, Robert, The Regions of Spain: A Reference Guide to History and Culture, Greenwood Press, 1995.

- Furst, R. Lilian, Women Healer And Physicians, UNS, The University Press Of California, 1997.

- Klein, Michele, A time to be born: customs and Folklore Of Jewish Birth, Jewish Publication Society. 